Review

\title{
Ironmaking and Steelmaking Slags as Sustainable Adsorbents for Industrial Effluents and Wastewater Treatment: A Critical Review of Properties, Performance, Challenges and Opportunities
}

\author{
James Manchisi ${ }^{1,2}$, Elias Matinde ${ }^{1,3, *}$, , Neil A. Rowson ${ }^{4}$, Mark J. H. Simmons ${ }^{4}$, \\ Geoffrey S. Simate ${ }^{1}$, Sehliselo Ndlovu ${ }^{1,5}$ and Brian Mwewa ${ }^{1,5}$ \\ 1 School of Chemical \& Metallurgical Engineering, University of Witwatersrand, Johannesburg 2050, South Africa; \\ jay.manchisi@gmail.com (J.M.); Geoffrey.Simate@wits.ac.za (G.S.S.); Sehliselo.Ndlovu@wits.ac.za (S.N.); \\ sirbhimself@yahoo.co.uk (B.M.) \\ 2 School of Mines, University of Zambia, Lusaka 32379, Zambia \\ 3 Pyrometallurgy Division, MINTEK, Praegville, Johannesburg 2125, South Africa \\ 4 School of Chemical Engineering, University of Birmingham, Birmingham B15 2TT, UK; \\ n.a.rowson@bham.ac.uk (N.A.R.); m.j.simmons@bham.ac.uk (M.J.H.S.) \\ 5 DST/NRF SARChI: Hydrometallurgy and Sustainable Development, School of Chemical and Metallurgical \\ Engineering, University of the Witwatersrand, Johannesburg 2050, South Africa \\ * Correspondence: eliasm@mintek.co.za
}

Received: 19 December 2019; Accepted: 14 February 2020; Published: 9 March 2020

check for updates

\begin{abstract}
This paper critically discusses the structure, properties and applications of ironmaking and steelmaking slags and their silicate-based variants as low-cost adsorbents for removing cations and anions from industrial effluents and wastewater. Undoubtedly, the performance of slag-based adsorbents depends on their physical, chemical and phase chemical properties. The presence of crystalline phases, for example, has a significant effect on the adsorption capacity. However, despite their low cost and ubiquity, their chemical and geometric heterogeneity significantly affects the performance and applications of slag-based adsorbents. These challenges notwithstanding, the efficacy of slag-based adsorbents can be significantly enhanced through purposeful activation to increase the specific surface area and density of adsorption sites on the surfaces of adsorbent particles. The synthesis of functionalised adsorbents such as geopolymers, zeolites and layered double hydroxides from silicate and aluminosilicate precursors can also significantly increase the performance of slag-based adsorbents. In addition, the ability to stabilise the dissolved and/or entrained toxic metal species in stable phases in slags, either through controlled post-process fluxing or crystallisation, can significantly enhance the environmental performance of slag-based adsorbents. Most critical in the design of future slag-based adsorbents is the integration of the engineered properties of molten and solidified slags to the recovery and stabilisation of dissolved and/or entrained metals.
\end{abstract}

Keywords: low cost adsorbents; multi-solute systems; activated slags; zeolites; permeable reactive media; concomitant solubility; factor sp; environmental performance; glass-ceramics

\section{Introduction}

The use of adsorption as a separation technology dates back to ancient civilisations, and has its origins as an industrial process after the discovery of gas uptake by charcoal and clays [1]. Adsorption is simply a mass transfer process through which solute species are transferred from a fluid phase onto the surface of a solid phase. The adsorbed species become bound to the surface of the solid by 
physicochemical interactions [1-5]. In view of the simplicity of their design and their ease of operation, adsorption technologies are now widely used in various industrial processes such as in the treatment of industrial effluents and wastewater, separation of petroleum products, separation of fluid mixtures and in the neutralisation of waste gases, among others [1-4].

As a result of the anthropogenic discharge of industrial effluents and wastewater, the use of adsorption technologies to treat these fluid streams has attracted universal interest from researchers globally. To date, several studies have focused on the ideal characteristic properties of adsorbents such as large internal pore volume, large internal surface area, active surface properties and/or functional groups, pore size distribution, weak adsorbate/adsorbent interactions, chemical, thermal and mechanical stability and the cost of constituent materials [1-4,6,7]. Adsorbents can essentially be described as amorphous materials consisting of complex networks of interconnected micropores $(\Phi<2 \mathrm{~nm})$, mesopores $(2 \mathrm{~nm}<\Phi<50 \mathrm{~nm})$ and macropores $(\Phi>50 \mathrm{~nm})$ [8,9]. Ideally, a highly porous adsorbent with a large surface area is especially important for fast adsorption equilibrium kinetics and high adsorption capacities in commercial applications (Table 1). The pore structure, particularly the pore size, shape and pore size distribution properties, is also of particular importance to the adsorption capacity of adsorbents.

The characteristic adsorbent requirements, such as high adsorption capacity, fast adsorption kinetics, good reusability and low cost, are critical in the practical design of adsorption processes $[3,4,6]$. Commercial adsorbents must also possess good mechanical properties such as strength and attrition resistance, as well as high adsorptive, regenerative and recyclability capacities. In other words, the adsorbents should have a high ability to be both regenerated and recycled without losing their mechanical and adsorptive properties. These properties are considered to be critical in enhancing the economics of adsorption processes.

Table 1 gives a summary of a selected number of commercial adsorbents and some of their properties.

Table 1. Examples and properties of commercial adsorbents [10].

\begin{tabular}{|c|c|c|c|c|c|}
\hline Adsorbent & Nature & $\begin{array}{c}\text { Pore Diameter, } \\
\quad d_{p}(\hat{A})\end{array}$ & $\begin{array}{c}\text { Particle } \\
\text { Porosity, } \varepsilon_{p}\end{array}$ & $\begin{array}{l}\text { Particle Density } \\
\quad\left(\mathrm{g} \mathrm{cm}^{-3}\right)\end{array}$ & $\begin{array}{c}\text { Surface Area } \\
\left(\mathrm{m}^{2} \mathrm{~g}^{-1}\right)\end{array}$ \\
\hline Activated alumina & $\begin{array}{l}\text { Hydrophilic; } \\
\text { amorphous }\end{array}$ & $10-75$ & 0.50 & 1.25 & 320 \\
\hline Silica gel (small pore) & \multirow{2}{*}{$\begin{array}{l}\text { Hydrophilic/ } \\
\text { hydrophobic; } \\
\text { amorphous }\end{array}$} & $22-26$ & 0.47 & 1.09 & $750-850$ \\
\hline Silica gel (large pore) & & $100-150$ & 0.71 & 0.62 & $300-350$ \\
\hline $\begin{array}{l}\text { Activated carbon } \\
\text { (small pore) }\end{array}$ & \multirow{2}{*}{$\begin{array}{l}\text { Hydrophobic; } \\
\text { amorphous }\end{array}$} & $10-25$ & $0.4-0.6$ & $0.5-0.9$ & $400-1200$ \\
\hline $\begin{array}{l}\text { Activated carbon } \\
\text { (large pore) }\end{array}$ & & $>30$ & - & $0.6-0.8$ & $200-600$ \\
\hline Molecular sieve carbon & Hydrophobic & $2-10$ & - & 0.98 & 400 \\
\hline $\begin{array}{l}\text { Molecular sieve } \\
\text { zeolites }\end{array}$ & $\begin{array}{l}\text { Polar hydrophilic; } \\
\text { crystalline }\end{array}$ & $3-10$ & $0.2-0.5$ & 1.4 & $600-700$ \\
\hline Polymeric adsorbents & - & $40-25$ & $0.4-0.55$ & - & $80-700$ \\
\hline
\end{tabular}

For centuries, activated carbon has been one of the most commonly used commercial adsorbents in the treatment of industrial effluents and wastewater [1,3,4]. It is currently considered the world's most powerful adsorbent, and is applicable for the removal of a variety of problematic pollutants such as metal ions, phenols, dyes, pesticides, polychlorinated phenols, chlorinated hydrocarbons and detergents, among others, from wastewater and industrial effluents [2,11,12]. There is no doubt that activated carbon is a ubiquitous adsorbent material that provides a combination of high surface area per unit volume, desirable mechanical properties and high adsorptive and regenerative capacities $[2,4,11]$.

Activated carbon is produced from carbonaceous materials such as various grades of coal (bituminous, subbituminous and lignite), petroleum coke, peat, wood or nutshells [12]. The processes used to produce activated carbons from these feedstocks can be grouped into two main steps, namely (a) thermal devolatisation $\left(400-600{ }^{\circ} \mathrm{C}\right.$ in an oxygen-deficient atmosphere) followed by the gasification 
of the devolatised char with an oxidising agent, and (b) chemical activation, in which the carbonisation and chemical activation are conducted concomitantly [11-13]. The thermal and chemical activation treatments thus produce a product that is not only microporous, but also contains a significant amount of mesopores and macropores [13]. The presence of the mesopores, micropores and macropores facilitates the access of adsorbate molecules to the interior of the carbon particles. These properties thus enable the activated carbon to possess excellent adsorptive properties due to the high surface area per unit volume [13].

Despite its utility as an adsorbent, activated carbon is an expensive material, the properties of which are largely dependent on the quality of the starting carbonaceous material and the particular activation process used $[4,11,12]$. As a result, there is growing interest in developing alternative low-cost adsorbents such as natural and synthetic zeolites and industrial waste byproducts (e.g., metallurgical slags, fly ash and agricultural wastes). To date, several studies have reported satisfactory adsorptive properties of these low-cost adsorbent materials, as well as their potential to be activated in order to improve their adsorption capabilities [2-4,14-19]. Among the low-cost adsorbents investigated so far, the application of metallurgical slags and other aluminosilicate-based industrial waste byproducts as low-cost and sustainable adsorbents has drawn considerable interests from many scientists globally.

Metallurgical slags play indispensable roles in the efficient extraction and refining of metals [20-22]. They are formed from the reaction between fluxes, intentionally added as part of the furnace charge, and gangue minerals in ores during the smelting process, or from the reaction between fluxes and dissolved impurities during refining [20-22]. Fluxing produces a low liquidus and complex slag melt which is immiscible with the metal and/or alloy phases, and is thus easily separated during tapping [20,22]. These materials not only play a role in controlling the metallurgical efficiency of smelting and refining processes, but are also critical in improving the energy efficiency [23]. Unfortunately, metallurgical slags constitute a high volume of waste byproducts in most pyrometallurgical processes. Currently, large volumes of solidified slags are disposed of in landfills. However, the disposal of slags in landfills creates long-term environmental challenges [22-24]. In order to mitigate the anthropogenic effects of process slags, it is therefore imperative to explore alternative utilisation options and to reduce the amounts that end up in landfills [22-25]. Thus, the alternative use of slags as sustainable and low-cost adsorbents is one such approach that can increase the valorisation potential of these materials [3,4,22-25].

This review paper discusses the application of metallurgical slags and their silicate-based variants as low-cost adsorbents for removing cations and anions from industrial effluents and wastewater. This review paper is structured as follows. After the introductory remarks already given, Section 2 provides a brief overview of adsorption, adsorption isotherms and applicable kinetic models. Section 3 provides a detailed overview of sources, types and physicochemical (physical, chemical and phase chemical composition) properties of ironmaking and steelmaking slags. Section 4 provides a detailed analysis of the applications of ironmaking and steelmaking slags as low-cost adsorbents. Section 5 highlights the opportunities to improve the performance of ironmaking and steelmaking slag adsorbents. Lastly, Sections 6 and 7 highlights the environmental challenges and future prospects, respectively, while Section 8 is the conclusion.

\section{Basic Principles of the Adsorption Process}

The heterogeneity of adsorbent surfaces significantly affects their adsorption equilibrium and kinetics. Heterogeneous adsorbents contain multiple adsorption sites wherein the adsorbates can bind, with each site having individual heats of adsorption $[9,26]$. Adsorbent and adsorbate properties also determine whether the nature of interaction is physisorption or chemisorption. Physisorption is as a result of weak and reversible electrostatic and intermolecular van der Waals attractions between the adsorbent and sorbate molecules $[9,26,27]$. In contrast, chemisorption is characterised by stronger forces of attraction, such as covalent bonding or ligand-metal coordination bonds. Thus, it is difficult to remove chemisorbed species from the solid surface $[9,26]$. 
The design and control of adsorption processes require in-depth knowledge of equilibria, kinetics and thermodynamics. For practical applications of adsorption, it is important to model the adsorption rates, and to establish the time dependence of adsorption systems under various process conditions [28-33]. Technically, the adsorption capacity and the resulting adsorption mechanisms depend on the characteristics of the adsorbates and adsorbents, adsorbate-adsorbent interactions and system conditions such as $\mathrm{pH}$, temperature and solute concentration, among others $[3,26,34]$. In addition, the physicochemical surface properties of adsorbents provide significant insights into the adsorption mechanisms and the degree of affinity of adsorbents [31].

Basically, the process of adsorption involves the following mechanistic steps [5,26,34]: (1) film diffusion (external diffusion) from the bulk fluid phase to the external surface of the adsorbent, (2) pore diffusion (or intraparticle diffusion) from the external surface into the pores of the adsorbent and (3) reaction of the adsorbate on the adsorbent active sites on the external surface or in the pores. The overall rate of adsorption depends on the cumulative sum of the mass transfer resistances of these three mechanistic steps [26]. Any one of the three mechanistic steps already stated can be rate-limiting, but the quantum of the rate limiting step depends on the interaction of several factors, such as adsorbent and adsorbate types and properties, and operating conditions [26]. The adsorption of dissolved metal ions in particular can be described as a sequential process of metal ion diffusion through the boundary layer, intraparticle diffusion and adsorption of ions onto the adsorbent surface [6,7]. Both chemical reaction and diffusion-based mathematical models are frequently used to analyse kinetic data from adsorption processes. The following subsection covers the fundamentals of adsorption isotherms and kinetic models.

\subsection{Adsorption Isotherms}

An adsorption isotherm is a set of equilibrium capacity data over a range of fluid-phase concentrations at fixed temperature [29]. The isotherms govern the retention, release or mobility of an adsorbate from an aqueous phase to a solid phase at constant $\mathrm{pH}$ and temperature [31]. The isotherms also provide the theoretical adsorption capacity, and are important tools used in model analysis, process design and operation of adsorption systems $[1,29,30]$. Amongs the several adsorption isotherm models available in literature, the Langmuir (Equation (1)) and Freundlich (Equation (2)) isotherms are commonly used to determine the capacities of different adsorbents $[3,28,30,31,33]$.

$$
\begin{gathered}
\text { Langmuir: } q_{e}=\frac{Q_{o} \times b \times C_{e}}{1+b \times C_{e}} \\
\text { Freundlich : } q_{e}=K_{f} \times C_{e}^{1 / n} ; n>1
\end{gathered}
$$

where $q_{e}\left(\mathrm{mg} \mathrm{g}^{-1}\right)$ is the equilibrium sorption capacity, $Q_{o}$ is the maximum amount of solute adsorbed per unit mass of adsorbent corresponding to complete coverage of available adsorption sites, $C_{e}$ is the equilibrium solute concentration in solution $\left(\mathrm{mg} \mathrm{L}^{-1}\right), b$ is the Langmuir adsorption coefficient, $K_{f}$ is the temperature-dependent Freundlich constant related to maximum adsorption capacity $\left(\mathrm{mg} \mathrm{g}^{-1}\right)$ and $n$ is the dimensionless Freundlich constant related to surface heterogeneity.

The Langmuir isotherm assumes monolayer adsorption onto a surface containing a finite number of energetically identical adsorption sites. Once the sites are filled, no further sorption can take place on that surface, and the surface eventually reaches a saturation point where the maximum adsorption of the surface has been achieved. Thus, Langmuir isotherms are valid for dynamic equilibrium adsorption processes on homogenous surfaces with no transmigration of the adsorbate in the plane of the surface, and negligible interaction between the adsorbed species [3,29,31]. In contrast, the Freundlich isotherm is commonly used to describe adsorption characteristics for heterogeneous surfaces and/or where strong interaction are present between adsorbate species. The model can be applied to multilayer adsorption, with non-uniform distribution of adsorption heats and affinities over the heterogeneous surfaces $([3,29,31])$. 


\subsection{Kinetic Models}

The kinetics of an adsorption process is dependent on the physicochemical characteristics of adsorbents and adsorbates, and on hydrodynamic and system parameters such as $\mathrm{pH}$, agitation and temperature $[3,5,26,34]$. Kinetic isotherms, plotted as uptake vs. time, are typically used to represent the kinetics of adsorption [26]. The rate of transfer of adsorbates from the bulk fluid phase to the adsorbent surface and their accumulation on the adsorbent surface, determine the overall kinetics of adsorption and hence, the efficiency of the adsorption process [34]. In essence, the determination of kinetic models of adsorption parameters allows for the design and scale-up of an adsorption system, which basically requires knowledge of adsorption equilibrium and kinetics [5,28,34].

To date, several kinetic models have been developed to describe the rates of adsorption systems based on the concentration of solutions and capacity of adsorbents $[3,28,35]$. Other models are based on the assumption that either sorption or intraparticle diffusion is the rate-limiting step [35]. Basically, both the chemical reaction and diffusion-based mathematical models are frequently used to analyse kinetic data from adsorption processes. Among the various models, most studies on adsorption have focussed on the Lagergren pseudo-first-order and Ho and Mackay's pseudo-second-order models to depict the rates of reaction $[5,26,28,34,35]$. However, Qui et al. [5] argued that the chemical reaction models, such as the pseudo-first- and second-order rate equations, are neither useful in understanding adsorption mechanisms nor helpful in designing fixed-bed systems. Instead, Qui et al. [5] advocate for the use of adsorption diffusion models such as liquid film diffusion, intraparticle diffusion and double exponential models. Nevertheless, it is important that the choice of models adopted achieves a balance between accuracy and simplicity.

\section{Sources, Types and Properties of Metallurgical Slags}

Metallurgical slags can broadly be categorised into nonferrous, ferroalloy and ferrous slags. Nonferrous slags are produced during the production of nonferrous metals from their ores and belong to the $\mathrm{FeO}-\mathrm{SiO}_{2}-\mathrm{CaO}$ slag system $[21,22,24]$. Ferroalloy slags are produced in the production of bulk ferroalloys, and predominantly consist of $\mathrm{SiO}_{2}, \mathrm{MgO}$ and $\mathrm{Al}_{2} \mathrm{O}_{3}$ as the main oxides. Ferrous slags, produced in the production of iron and steel products, belong to the $\mathrm{CaO}-\mathrm{SiO}_{2}-\mathrm{Al}_{2} \mathrm{O}_{3}-\mathrm{MgO}-\mathrm{FeO}$ system $[21-24,36]$. Among the various types of metallurgical slag systems, ferrous slags have attracted considerable interest due to the large volumes produced. In fact, the World Steel Association [37] estimates that over 400 million tonnes of ferrous slags are produced annually. Thus, exploring the use of these slags as low-cost adsorbents is beneficial in reducing the volumes of landfilled slags, thereby mitigating the storage and toxicity concerns associated with their disposal [22,23,25]).

Ironmaking and steelmaking slags are categorised according to the unit processes in which they are produced [21-24,36]. Ironmaking slags are produced during the conversion of iron oxides, pellets, sinter and fluxes in the presence of coke to produce hot metal in a blast furnace. A modern blast furnace (BF) process operating at typical cut-off iron ore grades (60-66 wt. \% Fe) produces about 200-300 kg of slag per ton of hot metal [22-24,38]. In contrast, steelmaking slags are produced from the melting of scrap metals in an electric arc furnace (EAF) to produce liquid steel, or from the conversion and refining of hot metal in oxygen steelmaking and ladle refining. Depending on the quality of raw materials, the slag rate in a basic oxygen furnace (BOF) or EAF ranges between 150-200 kg and 130-180 kg per ton of steel, respectively [22,23]. Steelmaking slags consist primarily of $\mathrm{CaO}, \mathrm{MgO}, \mathrm{SiO}_{2}$ and $\mathrm{FeO}$, and can thus be represented by the $\mathrm{CaO}-\mathrm{SiO}_{2}-\mathrm{MgO}-\mathrm{FeO}$ quaternary system $[22,23,39]$.

\subsection{Chemical Properties of Ironmaking and Steelmaking Slags}

\subsubsection{Blast Furnace Slags}

The chemical and phase compositions of blast furnace slags (BFS) have been studied by several researchers [21-23,38,40-49]. Blast furnace slags belong to the $\mathrm{CaO}-\mathrm{SiO}_{2}-\mathrm{MgO}$ system, and may contain minor oxide components such as $\mathrm{MnO}, \mathrm{FeO}, \mathrm{Na}_{2} \mathrm{O}, \mathrm{S}$ and $\mathrm{K}_{2} \mathrm{O}$, among others [21]. Talling and 
Krivenko [41] reported the typical composition of blast furnace slag to consist of 30-50 wt. \% CaO, $28-40$ wt. $\% \mathrm{SiO}_{2}, 8-24$ wt. $\% \mathrm{Al}_{2} \mathrm{O}_{3}$ and 1-18 wt. \% MgO. Rao [45] proposed the typical composition of blast furnace slags to consist of $34-43$ wt. \% CaO, $27-38$ wt. $\% \mathrm{SiO}_{2}, 7-12$ wt. $\% \mathrm{Al}_{2} \mathrm{O}_{3}, 7-15$ wt. \% MgO, 0.15-0.76 wt. \% $\mathrm{MnO}, 0.2-1.6$ wt. \% FeO and 1.0-1.9 wt. \% S. In other studies, Dimitrova and Mehandgiev [42] also reported the chemical properties of blast furnace slags as containing high amounts of $\mathrm{BaO}(3-3.5$ wt. \% $\mathrm{BaO})$. Table 2 shows the typical chemical compositions (un-normalised) reported for blast furnace slags.

Table 2. Typical chemical composition of blast furnace slags.

\begin{tabular}{|c|c|c|c|c|c|c|c|}
\hline \multicolumn{8}{|c|}{ Composition (wt. \%) } \\
\hline $\mathrm{CaO}$ & $\mathrm{SiO}_{2}$ & $\mathrm{Al}_{2} \mathrm{O}_{3}$ & $\mathrm{MgO}$ & $\mathrm{MnO}$ & $\mathrm{FeO}$ & $S$ & References \\
\hline $30-50$ & $28-40$ & $8-24$ & $1-18$ & na & na & na & [41] \\
\hline $36-45$ & $33-42$ & $10-16$ & $3-16$ & $\leq 2$ & na & na & [40] \\
\hline 33.7 & 35.1 & 10.6 & 14.4 & 0.5 & 0.4 & 0.8 & [46] \\
\hline 41.7 & 33.8 & 13.4 & 7.4 & 0.3 & 0.5 & 0.8 & [47] \\
\hline $35-42$ & $35-40$ & $8-15$ & $8-9$ & $0.3-1.0$ & $0.5-0.8$ & $0.7-1.5$ & [21] \\
\hline $34-43$ & $27-38$ & $7-12$ & 7-15 & $0.15-0.76$ & $0.2-1.6$ & $1.0-1.9$ & [45] \\
\hline $30-56$ & $28-38$ & $8-24$ & $1-18$ & $0.5-2$ & $0.5-1$ & na & [38] \\
\hline $35-42$ & $33-38$ & $10-15$ & $7-12$ & $\leq 1$ & $\leq 1$ & $1-1.5$ & [44] \\
\hline
\end{tabular}

\subsubsection{Steelmaking Slags}

The composition of steelmaking slags varies greatly from batch to batch, depending on the type of steel produced (e.g., carbon steel vs. stainless steels) and on the quality of starting raw materials $[22,23,36,45,48-50]$ (Table 3). BOF slags, for example, tend to have a high CaO content ( $>35$ wt. $\% \mathrm{CaO}$, and up to 12 wt. \% free $\mathrm{CaO}$ ), up to 38 wt. \% iron oxides $\left(\mathrm{FeO} / \mathrm{Fe}_{2} \mathrm{O}_{3}\right), 7-18$ wt. $\% \mathrm{SiO}_{2}$, 0.5-4 wt. \% $\mathrm{Al}_{2} \mathrm{O}_{3}$ and $0.4-14$ wt. \% $\mathrm{MgO}$ [36]. The chemical compositions of EAF slags also vary greatly and have been reported to consist of $22-60 \mathrm{wt}$. $\% \mathrm{CaO}, 10-40 \mathrm{wt}$. \% $\mathrm{FeO}, 6-34 \mathrm{wt}$. \% $\mathrm{SiO}_{2}$, 3-14 wt. \% $\mathrm{Al}_{2} \mathrm{O}_{3}, 3-13$ wt. \% $\mathrm{MgO}$ and varying amounts of free $\mathrm{CaO}$ and $\mathrm{MgO}[22,23,36]$. According to Rao [45], BOF, open hearth, EAF and ladle slags tend to have a broad chemical composition consisting of high $\mathrm{FeO}$ (6.8-23.4 wt. \%), 39.9-52.2 wt. \% $\mathrm{CaO}, 4.6-12.8$ wt. \% $\mathrm{SiO}_{2}, 1.3-20.5$ wt. \% $\mathrm{MgO}$ and $1.9-9.3$ wt. \% MnO. From the studies highlighted so far, there seem to be strong similarities between $\mathrm{BOF}$ and EAF slags due to similar refining functions of these two processes [22,23,36,45]. Ladle furnace slags (LFS), particularly those produced in the production of stainless and other high-alloy steels, are also strongly dependent on the grade of steel produced [22,23,50,51]. For example, Shi [39] reported the composition of ladle furnace slags to vary within a broad compositional range of $30-60 \% \mathrm{CaO}$, $2-35 \% \mathrm{SiO}_{2}, 5-35 \% \mathrm{Al}_{2} \mathrm{O}_{3}, 1-10 \% \mathrm{MgO}$ and $0.1-15 \% \mathrm{FeO}$.

As shown in Table 3, the wide compositional variability and presence of toxic alloying elements in steelmaking slags presents challenges to their potential utilisation as low-cost adsorbents. The following subsection further highlights the phase chemical compositions of solidified ironmaking and steelmaking slags. 
Table 3. Typical chemical composition (un-normalised) of various steelmaking slags.

\begin{tabular}{|c|c|c|c|c|c|c|c|c|c|c|c|}
\hline \multirow{2}{*}{ Slag Type } & \multicolumn{10}{|c|}{ Chemical Composition (wt. \%) } & \multirow{2}{*}{ References } \\
\hline & $\mathrm{CaO}$ & $\mathrm{SiO}_{2}$ & $\mathrm{Al}_{2} \mathrm{O}_{3}$ & $\mathrm{MgO}$ & $\mathrm{FeO}$ & $\mathrm{Fe}_{2} \mathrm{O}_{3}$ & $\mathrm{MnO}$ & $\mathrm{P}_{2} \mathrm{O}_{5}$ & $\mathrm{TiO}_{2}$ & $\mathrm{Cr}_{2} \mathrm{O}_{3}$ & \\
\hline $\mathrm{BOF}$ & $45-60$ & $10-15$ & $1-5$ & $3-13$ & $7-20$ & $3-9$ & $2-6$ & $1-4$ & na & na & [49] \\
\hline $\mathrm{BOF}$ & 39.40 & 11.97 & 2.16 & 9.69 & 30.23 & na & 2.74 & 1.00 & 0.40 & 0.20 & [36] \\
\hline $\mathrm{BOF}$ & 47.71 & 13.25 & 3.04 & 6.37 & na & 24.36 & 2.64 & 1.47 & 0.67 & 0.19 & [50] \\
\hline BOF & 47.9 & 12.2 & 1.2 & 0.8 & 26.3 & na & 0.3 & 3.3 & na & na & [48] \\
\hline BOF & $30-55$ & $8-20$ & $1-6$ & $5-15$ & $10-35$ & na & $2-8$ & $\leq 2$ & $0.4-2$ & $\leq 0.73$ & [39] \\
\hline BOF & $42-55$ & $12-18$ & $\leq 3$ & $\leq 8$ & na & na & $\leq 5$ & $\leq 2$ & na & $\leq 10$ & [40] \\
\hline EAF & $30-50$ & $11-20$ & $10-18$ & $8-13$ & $8-22$ & $5-6$ & $5-10$ & $2-5$ & na & na & [49] \\
\hline EAF (carbon steel) & $30-60$ & $9-20$ & & $5-15$ & $15-30$ & na & $3-8$ & $\leq 0.58$ & na & $0.15-1.5$ & [39] \\
\hline EAF & 45.5 & 32.2 & 3.7 & 5.2 & 3.3 & 1.0 & 2.0 & na & 0.13 & 0.05 & [52] \\
\hline EAF & 46.9 & 33.5 & 2.30 & 6.22 & 1.07 & 0.36 & 2.60 & 0.02 & 0.16 & 2.92 & [53] \\
\hline EAF (stainless steel) & $39-45$ & $24-32$ & $3-7.5$ & $8-15$ & $1-6$ & na & $0.4-2$ & $\leq 0.16$ & na & $0.15-29.2$ & [39] \\
\hline EAF & $25-40$ & $10-17$ & $4-7$ & $4-15$ & na & na & $\leq 6$ & $\leq 1.5$ & na & $\leq 3$ & [40] \\
\hline Ladle & $30-60$ & $2-35$ & $5-35$ & $1-10$ & $0.1-1.5$ & na & $0-5$ & $\leq 0.9$ & na & $\leq 0.73$ & [39] \\
\hline Ladle & 55 & 15 & 12.5 & 7.5 & na & 2.1 & 0.36 & na & 0.33 & 0.01 & [51] \\
\hline
\end{tabular}

na: not available; EAF (CS): electric arc furnace (carbon steel); EAF (A/S.S): electric arc furnace (alloy/ stainless steel. 


\subsection{Phase Chemical Properties of Ironmaking and Steelmaking Slags}

Knowledge of phase chemical properties of ferrous slags is essential, mainly because their adsorptive capacities are closely linked to these properties. Solid crystal formation is a function of both the chemical composition of the melt and its cooling rate $[22,36,54]$. Thus, the phase chemical properties of solidified slags largely depend on both the chemistry of the melt and the methods and processes used to cool the slags after tapping from the furnace [22-24,36,44,54]. Essentially, tapped process slags can be cooled and solidified in several different ways, including the following: (1) slow cooling under atmospheric conditions in slag pots or pads to produce a crystalline and vesicular slag product, (2) quenching using water jets to produce a vitrified granulated slag, (3) moderate cooling using controlled amounts of water or steam to form expanded, highly porous and low density slags and (4) quick cooling with water or in air using a pelletizing drum, producing glassy spherical slag particles. In most cases, slow-cooling and granulation represent the majority of slag-processing options for most iron and steel plants globally [23,44].

Slow-cooled blast furnace slag (s-BFS) consists of crystallised Ca-Al-Mg silicates, mostly as melilite $\left(\mathrm{Ca}_{2} \mathrm{MgSi}_{2} \mathrm{O}_{7}-\mathrm{Ca}_{2} \mathrm{Al}_{2} \mathrm{SiO}_{7}\right)$ and merwinite $\left(\mathrm{Ca}_{3} \mathrm{MgSi}_{2} \mathrm{O}_{8}\right)$ [21-23,44,48]. Little or no crystallization takes place in granulated BFS ( $\mathrm{g}-\mathrm{BFS}$ ), leading to the formation of glassy amorphous phases as a result of the vitreous solidification process [22,23]. In contrast, both slow-cooled and granulated steelmaking slags tend to form more complex oxides and silicates upon solidification (Table 4), and essentially tend to exist as complex and heterogeneous phases containing merwinite $\left(3 \mathrm{CaO} \cdot \mathrm{MgO} \cdot 2 \mathrm{SiO}_{2}\right)$, olivine $\left(2 \mathrm{MgO} \cdot 2 \mathrm{FeO} \cdot \mathrm{SiO}_{2}\right)$, di- and tricalcium silicates $\left(2 \mathrm{CaO} \cdot \mathrm{SiO}_{2} ; 3 \mathrm{CaO} \cdot \mathrm{SiO}_{2}\right), \mathrm{CaO}-\mathrm{FeO}-\mathrm{MnO}-\mathrm{MgO}$ solid solution phases, free lime ( $\mathrm{CaO}), \mathrm{MgO}$ and $\mathrm{FeO}[36,39,50,52,53,55,56]$.

The adsorption capacity of slags may depend on their degree of crystallisation attained during the solidification process. Several studies have investigated the effect of the degree of crystallinity on the absorptive capacity of ironmaking and steelmaking slags. The findings indicate that an increase in the amount of crystalline phases such as gehlenite $\left(\mathrm{Ca}_{2} \mathrm{Al}_{2} \mathrm{SiO}_{7}\right)$, larnite $\left(\mathrm{Ca}_{2} \mathrm{SiO}_{4}\right)$, bredigite $\left(\mathrm{Ca}_{5} \mathrm{MgSi}_{3} \mathrm{O}_{12}\right)$, merwinite $\left(\mathrm{Ca}_{3} \mathrm{Mg}\left(\mathrm{SiO}_{4}\right)_{2}\right)$ and akermanite $\left(\mathrm{Ca}_{2} \mathrm{MgSiO}_{7}\right)$, among others, significantly increases the adsorption capacity of cations and anions from solution $[15,19,25,57,58]$. However, since these phases may not always be uniformly present in the post-solidification state, several studies have explored in detail the impact of activation and modification on the adsorption capacities of slags [42,57,59-66]. Section 5 further discusses in detail the common modification and activation techniques and their impacts on the performance of slags. 
Table 4. Typical phase chemical characteristics and utilisation challenges of ironmaking and steelmaking slags.

Slag

Phase Chemical Properties

Glassy-amorphous and vitified phase

Crystallized mineral composition mainly

Granulated-Blast Furnace Slag (g-BFS)

consisting of melilite $\left(\mathrm{Ca}_{2} \mathrm{MgSi}_{2} \mathrm{O}_{7}-\mathrm{Ca}_{2} \mathrm{Al}_{2} \mathrm{SiO}_{7}\right)$,

and merwinite $\left(\mathrm{Ca}_{3} \mathrm{MgSi}_{2} \mathrm{O}_{8}\right)$.

$\mathrm{Ca}_{3} \mathrm{SiO}_{5} ; \alpha-\mathrm{Ca}_{2} \mathrm{SiO}_{4} ; \beta-\mathrm{Ca}_{2} \mathrm{SiO}_{4} ; 2 \mathrm{CaO} \cdot \mathrm{Fe}_{2} \mathrm{O}_{3} ;$ $\mathrm{CaO} ; \mathrm{MgO} ; 4 \mathrm{CaO} \cdot \mathrm{Al}_{2} \mathrm{O}_{3} \cdot \mathrm{Fe}_{2} \mathrm{O}_{3}$

Basic Oxygen Furnace (BOF) $\mathrm{CaO}-\mathrm{FeO}-\mathrm{MnO}-\mathrm{MgO}$ solid solution; wustite solid
solution; entrained metallic-Fe

$\mathrm{Fer}_{2} \mathrm{O}_{4} ; \mathrm{FeFe}_{2} \mathrm{O}_{4} ; \mathrm{Ni}$-Cr-Fe solid solution

$\mathrm{Ca}_{2} \mathrm{SiO}_{4} ; \mathrm{SiO}_{2} ; \mathrm{Ca}_{14} \mathrm{Mg}_{2}\left(\mathrm{SiO}_{4}\right)_{8} ; \mathrm{CaCrO}_{4} ;$

$\mathrm{Ca} 3 \mathrm{Mg}\left(\mathrm{SiO}_{4}\right)_{2} ; \mathrm{Ca}_{2} \mathrm{MgSi}_{2} \mathrm{O}_{7} ; \mathrm{Ca}_{2} \mathrm{Al}_{2} \mathrm{SiO}_{7}$

$(\mathrm{Ca}, \mathrm{Mn})_{2} \mathrm{SiO}_{4} ; \mathrm{Fe}-\mathrm{Cr}$-Ni intermetallic solid

Electric Arc Furnace (EAF)

solution; $(\mathrm{Mg}, \mathrm{Mn})(\mathrm{Cr}, \mathrm{Al}, \mathrm{Fe})_{2} \mathrm{O}_{4}$ spinel solid solution; $(\mathrm{Fe}, \mathrm{Mg}, \mathrm{Mn}) \mathrm{O}$ wustite type solid solution

$\mathrm{FeCr}_{2} \mathrm{O}_{4} ; \mathrm{FeFe}_{2} \mathrm{O}_{4} ; \mathrm{Ni}-\mathrm{Cr}$-Fe solid solution;

Ladle Furnace (stainless steel) $\mathrm{Ca}_{2} \mathrm{SiO}_{4} ; \mathrm{CaF}_{2} ; \mathrm{CaCrO}_{4} ; \mathrm{Ca}_{14} \mathrm{Mg}_{2}\left(\mathrm{SiO}_{4}\right)_{8} ; \mathrm{Ca}_{2} \mathrm{SiO}_{4}$ \begin{tabular}{l}
$\mathrm{Ca}_{4} \mathrm{Si}_{2} \mathrm{O}_{7} \mathrm{~F}_{2} ; \mathrm{MgO} ; \mathrm{Fe}-\mathrm{Cr} ; \mathrm{Fe}-\mathrm{Ni}$ \\
\hline
\end{tabular}
References

In addition to conventional uses as construction additives, $\mathrm{g}$-BFS and s-BFS can be adopted as adsorbents and geopolymers in the treatment and remediation of industrial effluents and wastewater (Section 3). Activation of BFS is conducted in order to increase their

The presence of free $\mathrm{CaO}$ and crystalline $\mathrm{Ca}-\mathrm{Al}-\mathrm{Mg}$ silicates imparts acid neutralisation and adsorption capacities, respectively. $\mathrm{The}^{\mathrm{SiO}_{2}}$ and $\mathrm{Al}_{2} \mathrm{O}_{3}$ are precursors to the synthesis of geopolymers, zeolites and layered double hydroxides from steelmaking slags (Section 5).

$[22,23,39,50,52]$

The presence of dissolved and/or entrained toxic alloying elements (e.g., $\mathrm{Cr}$ and Ni) limits the direct application of sto the direct application of steelmaking slag adsorbents. Thus, the long-term toxicity
haracteristic leaching properties (TCLPs) of slags are largely unknown and require furthe research (Section 6). Their utilisation could thus be enhanced by integrating with metal research (Section 6). Their utilisation could thus be enhanced by integrating with metal
recovery and/or slag-cleaning steps to produce environmentally benign residues for use as adsorbents (Section 6) 


\subsection{Physical Properties of Ironmaking and Steelmaking Slags}

Knowledge of the physical properties of slag-based adsorbents is important in the design of adsorption processes. From a practical point of view, adsorbents must have high selectivity and adsorption capacities, fast adsorption kinetics, high regeneration capabilities, good mechanical strength and low cost [8]. Among these, the adsorption capacity is by far the most important characteristic of adsorbents. The amount of adsorbate to be taken up, amount of adsorbent required, size of the adsorption vessel and capital costs largely depend on the adsorption capacity of the adsorbent selected [29]. To a greater extent, the pore structure of the adsorbent (pore sizes, shape and pore size distribution) largely determines its adsorption capacity. Consequently, a highly microporous structure with a high surface area is a requisite for high adsorption capacity by an adsorbent. Based on the aforementioned factors, this subsection discusses the key physical properties of ironmaking and steelmaking slags and their possible application as low-cost adsorbents.

The performance of ironmaking and steelmaking slags as low-cost adsorbents depends on their pore structure, pore area and volume and internal pore surface area $[8,62,68]$. These properties are particularly important since the pore structure (i.e., pore size, pore shape and pore distribution) of porous solids controls the internal pore volume and area [8]. Xue et al. [62] analysed the porosity of BOF slags, and their results suggested that the slag materials are mesoporous $\left(2<\mathrm{d}_{\mathrm{p}}<50 \mathrm{~nm}\right)$. Similarly, Curkovic et al. [67] and Liu et al. [69] deduced the mean pore diameter $\left(d_{p}\right)$ in steelmaking and EAF slags to be in the range of 17 to $27 \mathrm{~nm}$ and $12.58 \mathrm{~nm}$, respectively. Rađenović et al. [58] proposed ladle furnace slags to be mesoporous, with an average pore diameter and pore volume of $3.21 \mathrm{~nm}$ and $2.6 \times 10^{-3} \mathrm{~cm}^{3} \mathrm{~g}^{-1}$, respectively. The findings from various studies (Table 5) affirm the proposition that ironmaking and steelmaking slags can be considered mostly mesoporous, low-cost adsorbents.

Table 5. Selected properties of ironmaking and steelmaking slags of interest in the adsorption process.

\begin{tabular}{|c|c|c|c|c|c|}
\hline Material & $\begin{array}{l}\text { Surface Area } \\
\qquad\left(\mathrm{m}^{2} \mathrm{~g}^{-1}\right)\end{array}$ & $\begin{array}{l}\text { Pore Volume } \\
\left(\mathrm{cm}^{3} \mathrm{~g}^{-1}\right)\end{array}$ & $\begin{array}{c}\text { Mean Pore } \\
\text { Diameter, } d_{p}(\mathrm{~nm})\end{array}$ & Particle Size (d) & References \\
\hline BFS & 4.93 & na & na & $0.063-0.25 \mathrm{~mm}$ & [70] \\
\hline Granulated BFS & 1.63 & na & na & $\mathrm{d}<0.25 \mathrm{~mm}$ & \multirow{2}{*}{ [15] } \\
\hline Ungranulated BFS & 1.83 & na & na & $\mathrm{d}<0.25 \mathrm{~mm}$ & \\
\hline Granulated BFS & $\sim 1$ & na & na & $\begin{array}{c}\mathrm{d}<0.25 \mathrm{~mm} \& \\
0.50-1.25 \mathrm{~mm}\end{array}$ & [15] \\
\hline Granulated BFS & $0.3-0.5$ & na & na & $\begin{array}{c}\mathrm{d}<0.25 \mathrm{~mm} \text { and } \\
0.25-0.80 \mathrm{~mm}\end{array}$ & [42] \\
\hline EAF & 0.142 & na & 12.58 & $0.05-0.630 \mathrm{~mm}$ & [67] \\
\hline Ironmaking slag & 31.93 & na & na & $24.5 \mu \mathrm{m}$ & \multirow{2}{*}{ [71] } \\
\hline Steelmaking Slag & 22.33 & na & na & $24.1 \mu \mathrm{m}$ & \\
\hline Steelmaking slag & $0.82-1.85$ & na & $17-27$ & $0.85-0.08 \mathrm{~mm}$ & [69] \\
\hline Steelmaking slag & 0.29 & na & na & $0.5-1.0 \mathrm{~mm}$ & \\
\hline $\mathrm{EAF}_{\mathrm{BS}}$ slag & 3.42 & na & na & $0.9-2.0 \mathrm{~mm}$ & [72] \\
\hline BFS & 0.66 & 0.032 & 18.53 & $44-149 \mu \mathrm{m}$ & \multirow{2}{*}{ [25] } \\
\hline Steelmaking (BOF) slag & 7.34 & 0.028 & 15.9 & $44-149 \mu \mathrm{m}$ & \\
\hline $\begin{array}{l}\text { Steelmaking slags } \\
\text { (unmodified) }\end{array}$ & 7.52 & 11000 & 5.91 & $2000-4000 \mu \mathrm{m}$ & \multirow{2}{*}{ [63] } \\
\hline $\begin{array}{l}\text { Steelmaking slag } \\
\text { (modified) }\end{array}$ & 8.62 & 112000 & 5.58 & $2000-4000 \mu \mathrm{m}$ & \\
\hline Steelmaking slag & 30.27 & 0.028 & 30.72 & $\mathrm{~d}<1 \mathrm{~mm}$ & [73] \\
\hline LF slag & 3.04 & 0.0026 & 3.21 & $0.125-0.063 \mathrm{~mm}$ & [58] \\
\hline $\begin{array}{l}\text { Steelmaking slag } \\
\text { (unmodified) }\end{array}$ & 2.854 & 0.013 & na & $<0.25 \mathrm{~mm}$ & \multirow{2}{*}{ [64] } \\
\hline $\begin{array}{l}\text { Steelmaking slag } \\
\text { (modified) }\end{array}$ & 9.53 & 0.025 & na & $<0.25 \mathrm{~mm}$ & \\
\hline
\end{tabular}


Table 5. Cont.

\begin{tabular}{|c|c|c|c|c|c|}
\hline Material & $\begin{array}{l}\text { Surface Area } \\
\left(\mathrm{m}^{2} \mathrm{~g}^{-1}\right)\end{array}$ & $\begin{array}{l}\text { Pore Volume } \\
\qquad\left(\mathrm{cm}^{3} \mathrm{~g}^{-1}\right)\end{array}$ & $\begin{array}{c}\text { Mean Pore } \\
\text { Diameter, } d_{p}(\mathrm{~nm})\end{array}$ & Particle Size (d) & References \\
\hline BFS & 2.79 & 0.008 & 12.7 & na & \multirow{3}{*}{ [74] } \\
\hline BFS geopolymer & 64.5 & 0.070 & 5.93 & na & \\
\hline $\begin{array}{l}\text { Barium-modified BFS } \\
\text { geopolymer }\end{array}$ & 63.1 & 0.070 & 6.32 & na & \\
\hline
\end{tabular}

na: not available.

Ironmaking and steelmaking slags have a mesoporous and amorphous structure with a typically low specific surface area of less than $10 \mathrm{~m}^{2} \mathrm{~g}^{-1}[25,58,63,67,69,70,74]$, even though relatively high values of up to $32 \mathrm{~m}^{2} \mathrm{~g}^{-1}$ have been reported by Feng et al. [71] and Zahar et al. [73] (Table 5). Runtti et al. [74] also reported relatively higher values. Nevertheless, the typical and relatively low surface area in many slags shown in Table 5 potentially limits the amount of solute that can be adsorbed from industrial effluents and wastewater. However, the presence of both amorphous and crystalline phases in slags, highlighted in Table 4, fortunately enhances the adsorptive capacity for ions from solutions $[3,4,15,25,68]$. In addition, the reported porosity of typical slag-based adsorbents is in the range of $47 \%$ to $56 \%$, which is somewhat comparable to commercial zeolites, silica gels and activated $\mathrm{Al}_{2} \mathrm{O}_{3}[68]$.

\section{Applications and Performance of Slags as Low-cost Adsorbents}

The chemical composition (Tables 2 and 3), morphological phases (Table 4), physical properties (Table 5) as well as other properties such as the number of adsorption sites and type of surface functional groups all determine the mechanisms of adsorption and reactivity of the slag surfaces with adsorbates. For instance, the dissolution of free lime in the slag play a significant role in regulating the solution $\mathrm{pH}$ and hydrolysis of the dissolved cations [75,76]. In addition, the hydrolysis products of various chemical phases in slags dictate the mechanisms of bonding with adsorbates [70]. The adsorption performance is also a function of the slag type and its particle size distribution. A porous slag structure with a micropore size distribution $\left(d_{p}<2 \mathrm{~nm}\right)$ creates a large internal surface area for high adsorption capacity and efficiency of the adsorption process $[3,15,42,59,68,70,77]$. Specific experimental conditions such as agitation rate, temperature and solid/liquid phase ratio, and the solution conditions such as solution $\mathrm{pH}$, adsorbate types and concentration, ionic strength and competing adsorbates also affect the adsorption capacity of slags [3]. Based on the aforementioned considerations, this section gives a detailed review of the current understanding of the adsorption of heavy metal ions and other adsorbates by slags.

\subsection{Acid Neutralisation and Precipitation of Metal Ions}

Basic oxides have been extensively investigated in the precipitation of metal ions from industrial effluents. For example, limestone and its derivatives (e.g., quick lime, hydrated lime) are commonly used in the neutralisation and chemical precipitation of metal ions from acid mine drainage (AMD) effluents [78-80] and wastewater streams [16,81,82]. Since ironmaking and steelmaking slags contain significant amounts of basic oxides which combine useful properties of acid neutralisation, metal precipitation and adsorption, these materials can be considered as alternatives to lime-based chemical precipitation processes. For example, the dissolution and acid neutralisation behaviour of the various slag minerals were proposed in earlier studies by Bodurtha and Brassard [75]. The authors concluded that the slag materials had the same neutralisation capacity as calcite for AMD treatment, even when only $60 \%$ by volume of the slag was dissolved.

The acid neutralisation capacity (ANC) of ironmaking and steelmaking slags depends on the slag's chemical and phase composition [62,71,75,76,83,84]. As discussed in Section 3, ironmaking 
and steelmaking slags materials consist of complex mixture of oxides such as $\mathrm{CaO}, \mathrm{MgO}, \mathrm{FeO}, \mathrm{MnO}$, $\mathrm{Al}_{2} \mathrm{O}_{3}$ and $\mathrm{SiO}_{2}$. These oxides can undergo hydration reactions under aqueous conditions, thereby increasing their alkalinity, adsorption capacity and chemical precipitation ability for metal ions $[62,76,84]$. Ironmaking and steelmaking slags also contain significant amounts of lime (e.g., 30-50 wt. \% CaO for BOF slags) that occurs either freely or bound to various silicates and ferrites. It must be noted that the free $\mathrm{CaO}$ and $\mathrm{MgO}$ present in the slag dissolve completely, easily and rapidly in acidic aqueous systems to provide the largest and immediate contribution towards acid neutralisation (Equations (3)-(5)) [76].

$$
\begin{gathered}
\mathrm{MeO}+\mathrm{H}_{2} \mathrm{O} \rightarrow \mathrm{Me}(\mathrm{OH})_{2} \quad(\mathrm{Me}=\mathrm{Ca}, \mathrm{Mg}) \\
\mathrm{Me}(\mathrm{OH})_{2}+2 \mathrm{H}^{+} \rightarrow \mathrm{Me}^{2+}+2 \mathrm{H}_{2} \mathrm{O} \quad(\mathrm{Me}=\mathrm{Ca}, \mathrm{Mg}) \\
\mathrm{MeO}+2 \mathrm{H}^{+} \rightarrow \mathrm{Me}^{2+}+\mathrm{H}_{2} \mathrm{O} \quad(\mathrm{Me}=\mathrm{Ca}, \mathrm{Mg})
\end{gathered}
$$

In addition, the weakly bound $\mathrm{CaO}$ in compounds such as dicalcium silicate $\left(2 \mathrm{CaO} \cdot \mathrm{SiO}_{2}\right)$, tricalcium silicate $\left(3 \mathrm{CaO} \cdot \mathrm{SiO}_{2}\right)$ and dicalcium ferrite $\left(2 \mathrm{CaO} \cdot \mathrm{Fe}_{2} \mathrm{O}_{3}\right)$ also dissolves, albeit slowly, to consume the acid as well (Equations (6) and (7)).

$$
\begin{aligned}
& 2 \mathrm{Ca}_{2} \mathrm{SiO}_{4}+4 \mathrm{H}_{2} \mathrm{O} \rightarrow 3 \mathrm{CaO} \cdot 2 \mathrm{SiO}_{2} \cdot 3 \mathrm{H}_{2} \mathrm{O}+\mathrm{Ca}(\mathrm{OH})_{2} \\
& 2 \mathrm{Ca}_{3} \mathrm{SiO}_{5}+6 \mathrm{H}_{2} \mathrm{O} \rightarrow 3 \mathrm{CaO} \cdot 2 \mathrm{SiO}_{2} \cdot 3 \mathrm{H}_{2} \mathrm{O}+3 \mathrm{Ca}(\mathrm{OH})_{2}
\end{aligned}
$$

The adsorption of cations by slags is proposed to occur through electrochemical interactions on slag surfaces and by virtue of the high content of easily hydrolysable calcium and aluminium silicates. Based on surface models, Dimitrova [70] proposed the adsorption process to involve surface complex formation, precipitation, irreversible ion exchange, interaction of dissolved components of the slag with metal ions and the subsequent deposition of such products on slag adsorbent surfaces. Due to the complexity of adsorbent-adsorbate interactions, it is therefore important to understand the dissolution mechanisms of slags and their components in order to fully interpret the reactivity of slags and/or individually dissolved components of the slag with adsorbates $[62,71,75,76,83,84]$.

\subsection{Adsorption Capacity of Slags}

The quantity of adsorbate per unit mass of adsorbent (i.e., adsorption capacity, $\mathrm{mg} \mathrm{g}^{-1}$ ) to be taken up, kinetics and extent of adsorption vary depending on the type and physicochemical characteristics (e.g., specific surface area, pore size distribution and active-surface properties) of the adsorbent employed. These parameters are also a function of the experimental conditions employed (e.g., ionic strength, types and concentration levels of adsorbates, mixing time, competing adsorbates, agitation rate and temperature) $[42,62,67,69-71,84-87]$. This subsection briefly discusses the previous studies on the topics, focusing mainly on the adsorption capacity of slags. It further discusses the effect of adsorption parameters such as solution $\mathrm{pH}$, initial concentration of adsorbates, slag loading ratio and competitive multi-solute adsorption.

Yamashita et al. [87] proposed several assumptions governing metal adsorption on converter furnace steelmaking slag surfaces, including the following: (1) ion substitution caused by $\mathrm{CaO}$ and $\mathrm{MgO}$, (2) hydroxide precipitation at high $\mathrm{pH}$, (3) sulphide precipitation and co-precipitation by sulphur and iron oxides, respectively, and (4) possible adsorptive effects of the $2 \mathrm{CaO} \cdot \mathrm{SiO}_{2}$ phase. Dimitrova [70] proposed the process of adsorption to be facilitated by the chemical interaction of dissolved slag components with metal ions and the subsequent deposition of such products on slag surfaces. Several other studies have also proposed that the process of adsorption for metal ions with silicate-based adsorbents occurs through ion-exchange, adsorption and precipitation mechanisms $[42,71,83,88]$. In such cases, silicate and aluminosilicate phases in the slags undergo hydrolysis to support ion exchange and/or precipitation, depending on $\mathrm{pH}$ and metal ion concentration. However, in many 
instances, the proposed mechanisms of adsorption of metal ions by slags tend to be inconsistent and/or are not yet clearly understood.

Gao et al. [86] conducted experiments to investigate the adsorption and desorption of cations from effluent solutions using porous iron-rich slag $(0.1-0.5 \mathrm{~mm}$ particle sizes, $\approx 10000 \AA$ A macropore size, $10 \mathrm{~m}^{2} \mathrm{~g}^{-1}$ surface area and density $\left.3.5 \mathrm{~g} / \mathrm{cm}^{3}\right)$. X-ray diffraction analysis of the iron-rich slag identified the presence of wüstite $(\mathrm{FeO})$, magnetite $\left(\mathrm{Fe}_{3} \mathrm{O}_{4}\right)$, gypsum $\left(\mathrm{CaSO}_{4}\right)$ and akermanite $\left(\mathrm{Ca}_{2} \mathrm{MgSi}_{2} \mathrm{O}_{7}\right)$ as the major phases. The authors proposed a slow hydrolysis s of akermanite to release $\mathrm{OH}^{-}$ions responsible for maintaining an alkaline $\mathrm{pH}$, as described in Equation (8).

$$
\overline{\mathrm{Ca}_{2} \mathrm{MgSi}_{2} \mathrm{O}_{7}}+3 \mathrm{H}_{2} \mathrm{O} \rightarrow 2 \mathrm{Ca}^{2+}+\mathrm{Mg}^{2+}+6 \mathrm{OH}^{-}+2 \mathrm{SiO}_{2}
$$

where the overbar represents the adsorbent (solid) phase.

Adsorption tests by Gao et al. [86] indicated complete adsorption of metal ions at low initial concentrations $\left(\mathrm{Cd}^{2+}=\mathrm{Ni}^{2+}=\mathrm{Pb}^{2+}=2 \mathrm{mgL}^{-1} ; \mathrm{Cu}^{2+}=0.1 \mathrm{mg} \mathrm{L}^{-1} ; \mathrm{pH}=4\right)$. The adsorption selectivity sequence was $\mathrm{Pb}^{2+}>\mathrm{Cu}^{2+}>\mathrm{Ni}^{2+}>\mathrm{Cd}$ [86]. Gao et al. [86] proposed that the electrostatic and acid-base interactions in slags were responsible for the observed adsorption behaviour. In addition, the hydrolysis of akermanite eliminated the competitive adsorption of $\mathrm{H}^{+}$ions, thereby improving metal adsorption capacity. Furthermore, the approximated overall stoichiometry of metal adsorption involved both akermanite and surface adsorption sites on iron oxides, as shown in Equation (12). Gao et al. [86] proposed the hydrolysis of akermanite (Equation (9)) and intra-particle diffusion to be rate-limiting.

$$
\begin{aligned}
\overline{\mathrm{Ca}_{2} \mathrm{MgSi}_{2} \mathrm{O}_{7}}+2 \overline{\left(\equiv \mathrm{SO}^{-}\right) \mathrm{Na}^{+}}+6 \mathrm{H}^{+}+\mathrm{Me}^{2+}+3 \mathrm{H}_{2} \mathrm{O} \\
\\
\rightarrow 2 \mathrm{Ca}^{2+}+\mathrm{Mg}^{2+}+2 \mathrm{Na}^{+}+6 \mathrm{H}_{2} \mathrm{O}+\overline{2 \mathrm{SiO}_{2}}+\overline{\left(\equiv \mathrm{SO}^{-}\right)_{2} \mathrm{Me}^{2+}}
\end{aligned}
$$

where overbar + solid phase; $\equiv S O^{-}=$deprotonated surface site

Dimitrova [70] measured $\mathrm{Ca}^{2+}$ and $\mathrm{Si}^{4+}$ dissolution from BF slag in the absence and presence of $\mathrm{Zn}^{2+}$ ions as a function of temperature, and proposed the $\mathrm{Ca}^{2+}$ and $\mathrm{Si}^{4+}$ ions to result from the hydrolysis of $\mathrm{CaO}$ and $\mathrm{SiO}_{2}$ compounds in the slag, respectively. Based on the constant $\mathrm{CaO}: \mathrm{SiO}_{2}$ ratio in the system without $\mathrm{Zn}^{2+}$ ions, Dimitrova [70] concluded that the partial hydrolysis and hydration of $2 \mathrm{CaO} \cdot \mathrm{SiO}_{2}$ releases $\mathrm{Ca}^{2+}$ and $\mathrm{Si}^{4+}$ ions. However, the concentration of $\mathrm{Ca}^{2+}$ ions was several orders higher than that of $\mathrm{Si}^{4+}$ ions when $\mathrm{Zn}^{2+}$ ions were introduced, which suggested a non-equivalent ion exchange between $\mathrm{Ca}^{2+}$ and $\mathrm{Zn}^{2+}$ ions. The lack of equivalence during ion-exchange process was attributed to interactions of the metal ions with colloidal silica, as well as the variations in the amounts of soluble silicon.

Dimitrova and Mehandgiev [42] conducted batch adsorption experiments for $\mathrm{Pb}^{2+}$ ions using BFS. The study investigated the effect of initial $\mathrm{pH}\left(2 \leq \mathrm{pH} \leq 9\right.$, surface area $\left(0.3-0.5 \mathrm{~m}^{2} \mathrm{~g}^{-1}\right)$, adsorbent mass (1-10 $\left.\mathrm{g} \mathrm{L}^{-1} \mathrm{BFS}\right)$, metal ion concentration (13-93 $\mathrm{mg} \mathrm{L}^{-1} \mathrm{~Pb}^{2+}$ ) and ambient temperature on the equilibrium $\mathrm{pH}$ and adsorption efficiency. A $98 \%$ adsorption for $\mathrm{Pb}^{2+}$ ions was achieved, even at high solute concentrations of $92.6 \mathrm{mg} \mathrm{L}^{-1} \mathrm{~Pb}^{2+}$ ions, at $1 \mathrm{~g} \mathrm{~L}^{-1}$ BFS loading ratio and a $\mathrm{pH}$ range of 2-9. The findings also indicated that the equilibrium $\mathrm{pH}$ increased with increase in mass of BFS in the particle size range $0.25<d_{p}<0.50 \mathrm{~mm}$. The authors proposed an ion-exchange interaction process between the slag matrix and $\mathrm{H}^{+}$ions, particularly in highly acidic solutions [42].

Dimitrova and Mehandgiev [19] also explored mechanisms of adsorption of individual $\mathrm{Cu}^{2+}$, $\mathrm{Zn}^{2+}$ and $\mathrm{Ni}^{2+}$ ions by BF slag by measuring dissolved $\mathrm{Ca}^{2+}, \mathrm{Si}^{4+}$ and $\mathrm{pH}$ from slag hydrolysis. The authors proposed a non-equivalent ion-exchange behaviour between metal ions and $\mathrm{Ca}^{2+}$ ions as a result of the incomplete hydrolysis of the slag. In a similar study, Dimitrova et al. [15] also reported non-equivalent ion-exchange behaviour between $\mathrm{Cu}^{2+}$ and $\mathrm{Ca}^{2+}$ ions, and proposed that the high sorption of $\mathrm{Cu}^{2+}$ ions in activated crystalline slag, despite the observed decrease in surface area, was due to the creation of active adsorption sites through isomorphous substitution (type $\mathrm{Al}^{3+} \rightarrow \mathrm{Si}^{4+}$ ) induced during crystallisation. Furthermore, the study concluded that adsorption occurred both inside 
the crystal lattice and between the crystal spaces, compared to amorphous slag where adsorption was limited to the surface. In acidic $\mathrm{pH}$, the $\equiv \mathrm{SOH}$ sites ( $\mathrm{S}$ being $\mathrm{Si}$ or $\mathrm{Al}$ ) supported the adsorption of $\mathrm{Cu}^{2+}$ ions through a surface exchange mechanism (Equations (10)-(13)):

$$
\begin{gathered}
\overline{(\mathrm{Al}, \mathrm{SiO})_{2}^{-} \mathrm{Ca}^{2+}}+2 \mathrm{H}^{+} \rightarrow \overline{2(\mathrm{Al}, \mathrm{SiO})^{-}} \mathrm{H}^{+}+\mathrm{Ca}^{2+} \text { Blank solutions } \\
\overline{(\mathrm{Al}, \mathrm{SiO})_{2}^{-} \mathrm{Ca}^{2+}}+\mathrm{Me}^{2+} \rightarrow \overline{(\mathrm{Al}, \mathrm{SiO})_{2}^{-}} \mathrm{Me}^{2+}+\mathrm{Ca}^{2+}\left(\mathrm{Me}^{2+}=\mathrm{Cu}^{2+}, \mathrm{Zn}^{2+}, \mathrm{Ni}^{2+}\right) \\
\text { or } \overline{(\equiv \mathrm{SO})_{2}^{-}} 2 \mathrm{Ca}^{2+}+\mathrm{Me}^{2+} \rightarrow \overline{(\equiv \mathrm{SO})_{2}} \mathrm{Me}^{2+}+\mathrm{Ca}^{2+} \\
2 \mathrm{SOH}+\mathrm{Cu}^{2+}=(\mathrm{SO})_{2} \mathrm{Cu}+2 \mathrm{H}^{+}(\mathrm{S}=\mathrm{Al} \text { or } \mathrm{Si})
\end{gathered}
$$

where overbar $=$ solid phase,$(\equiv S O)=$ deprotonated surface site, $\mathrm{S}=\mathrm{Al}$ or $\mathrm{Si}$ and $\mathrm{Me}^{2+}=$ any metal ion.

Feng et al. [1] investigated comparative adsorption of $\mathrm{Cu}^{2+}$ and $\mathrm{Pb}^{2+}$ ions by ironmaking slag (unnormalised composition 46.3 wt. $\% \mathrm{CaO}, 5.9$ wt. $\% \mathrm{MgO}, 35.6$ wt. $\% \mathrm{SiO}_{2}, 10.3$ wt. $\% \mathrm{Al}_{2} \mathrm{O}_{3}$, 15.6 wt. \% FeO; surface area $31.929 \mathrm{~m}^{2} \mathrm{~g}^{-1}$ and porosity $55.5 \%$ ) and steelmaking slag (unnormalised composition 37.5 wt. \% CaO, 12.0 wt. \% MgO, 32.5 wt. \% $\mathrm{SiO}_{2}, 18.0$ wt. \% $\mathrm{Al}_{2} \mathrm{O}_{3}, 1.75$ wt. \% $\mathrm{FeO}$; surface area $22.333 \mathrm{~m}^{2} \mathrm{~g}^{-1}$ and porosity $47.3 \%$ ). The tests were conducted at ambient temperatures, initial $\mathrm{pH}=5.5$, ion concentrations $2 \mathrm{~g} \mathrm{~L}^{-1}$ slag and particle size $90 \%$ passing $45 \mu \mathrm{m}$. Due to the more favourable physicochemical properties of ironmaking slag, higher $\mathrm{Cu}^{2+}$ and $\mathrm{Pb}^{2+}$ adsorption was observed compared to that of steelmaking slag. In both slags, the loading of $\mathrm{Pb}^{2+}$ ions was higher than that of $\mathrm{Cu}^{2+}$ ions, with the adsorption behaviour being attributed to the preferential adsorption sites for $\mathrm{Pb}^{2+}$ ions on the slag surfaces (see Section 4.3.5). Using the Langmuir adsorption model, the maximum adsorption capacities $\left(Q_{\max }\right)$ for ironmaking slag were $95.34 \mathrm{mg} \mathrm{g}^{-1} \mathrm{~Pb}^{2+}$ and $88.50 \mathrm{mg} \mathrm{g}^{-1} \mathrm{Cu}^{2+}$. The $Q_{\max }$ values and Langmuir regression coefficients for the ironmaking slag were higher than those for steelmaking slag due to higher $\mathrm{CaO}$ content, higher specific surface area (i.e., ironmaking slag $=31.929 \mathrm{~m}^{2} \mathrm{~g}^{-1}$ and steelmaking slag $=22.33 \mathrm{~m}^{2} \mathrm{~g}^{-1}$ ), higher porosity (i.e., ironmaking slag $=55 \%$ and steelmaking slag $=47.3 \%$ ) and higher ion-exchange ability. Feng et al. concluded that the removal of metal ions occurred by both precipitation and ion exchange as a result of the high alkalinity of the slags. The authors also proposed that use of a finely sized slag fraction ( $90 \%$ passing $45 \mu \mathrm{m}$ ) nearly doubled the adsorption capacity of $\mathrm{Pb}^{2+}$ ions compared to values reported in literature for ironmaking slag with similar oxide composition but with coarser particle sizes [71].

Chen et al. [72] investigated the adsorption kinetics and equilibrium of $\mathrm{Cu}^{2+}, \mathrm{Cd}^{2+}, \mathrm{Zn}^{2+}$ and $\mathrm{Pb}^{2+}$ ions using two kinds of EAF slags from different steel plants in China. The two slags had the following properties: Slag 1: 42.30 wt. \%CaO, 9.82 wt. \% MgO, 5.28 wt. \% $\mathrm{Al}_{2} \mathrm{O}_{3}, 27$ wt. \% FeO, 3.31 wt. \% MnO, and 15.15 wt. $\% \mathrm{SiO}_{2}$; BET surface area $=3.148 \mathrm{~m}^{2} \mathrm{~g}^{-1}$; density $3.096 \mathrm{gcm}^{-3} ; \mathrm{pH}=10.69$; and Slag 2: 49.60 wt. \% CaO, 14.51 wt. \% $\mathrm{MgO}, 1.23$ wt. $\% \mathrm{Al}_{2} \mathrm{O}_{3}, 18.74$ wt. \%FeO, 1.28 wt. \% $\mathrm{MnO}$ and 14.66 wt. $\% \mathrm{SiO}_{2}$; BET surface area $=0.445 \mathrm{~m}^{2} \mathrm{~g}^{-1}$; density $3.974 \mathrm{~g} \mathrm{~cm}^{-3}$ and $\mathrm{pH}=11.75$. From a starting ion concentration of $2 \mathrm{mmolL}^{-1}$, the observed $\mathrm{Q}_{\max }$ for $\mathrm{Cu}^{2+}, \mathrm{Cd}^{2+}, \mathrm{Zn}^{2+}$ and $\mathrm{Pb}^{2+}$ on Slag $2(0.9-2.00 \mathrm{~mm})$ were $0.156,0.166,0.148$ and $0.145 \mathrm{mmol} \mathrm{g}^{-1}$, respectively, while those of Slag $1(0.9-2.00 \mathrm{~mm})$ were $0.101,0.058,0.112$ and $0.120 \mathrm{mmol} \mathrm{g}^{-1}$, respectively. The results indicated that Slag 2 had a higher adsorption capacity despite having a significantly lower BET surface area than Slag 1 . The findings were contrary to expectations from a physical property point of view, and could thus possibly be attributed to the higher $\mathrm{CaO}$ content coupled with the interaction of complex hydrolysis, ion-exchange and surface precipitation phenomena on the surfaces of Slag 2.

Han et al. [85] investigated the removal of hexavalent chromium $\left(\mathrm{Cr}^{6+}\right)$ ions $\left(75-150 \mathrm{mg} \mathrm{L}^{-1}\right)$ from wastewater using BOF slags with a normalised composition of 48 wt. $\% \mathrm{CaO}, 37$ wt. $\% \mathrm{Fe}_{2} \mathrm{O}_{3}$, $8 \mathrm{wt}$. $\% \mathrm{SiO}_{2}, 5$ wt. $\% \mathrm{MgO}$ and 2 wt. \% MnO. The removal of $\mathrm{Cr}^{6+}$ ions from wastewater was proposed to occur via a redox process in which the calcium and iron (as $\mathrm{FeO}, \mathrm{Fe}_{3} \mathrm{O}_{4}, \mathrm{Ca}_{2} \mathrm{Fe}_{2} \mathrm{O}_{5}$ and $\mathrm{CaFe}_{2} \mathrm{O}_{4}$ ) phases in the slag reacted with the acid to release $\mathrm{Fe}^{2+}$ and $\mathrm{Ca}^{2+}$ ions. According to Han et al. [85], the $\mathrm{Cr}^{6+}$ ion was subsequently reduced to insoluble $\mathrm{Cr}^{3+}$ by $\mathrm{Fe}^{2+}$ via a redox mechanism, thereby 
decreasing the amount of $\mathrm{Cr}^{6+}, \mathrm{Fe}^{2+}$ and $\mathrm{H}^{+}$ions in solution while increasing $\mathrm{Cr}^{3+}$ and $\mathrm{Fe}^{3+}$ ions. More recently, Gao et al. [84] also proposed that the slag must initially dissolve to release $\mathrm{Ca}^{2+}$ ions which then interact with metal ions to form precipitates that are subsequently adsorbed on the slag surfaces.

Table 6 further summarises the findings from the various studies on the adsorption capacities of ironmaking and steelmaking slags. These studies elucidated the efficacy of solute adsorption based on the adsorption behaviour of heavy metal ions by the slags. However, the interpretations, comparisons and predictions of the adsorption data proposed by the various authors vary greatly, possibly compounded by the heterogeneous nature of the slags. Thus, the differences in observations may complicate any protracted efforts to engineer the specific properties of ironmaking and steelmaking slags and enhance their adsorption capacities. Nevertheless, the various studies highlighted so far have converged on the technical and economic merit of ironmaking and steelmaking slags as low-cost adsorbents for remediating industrial effluents and wastewaters. Section 6 of this paper further discusses some of the promising approaches being pursued to enhance the adsorptive capacities of ironmaking and steelmaking slags. 
Table 6. Reported maximum adsorption capacities and efficiencies of various unmodified slag materials.

\begin{tabular}{|c|c|c|c|c|c|c|}
\hline Slag Type & $\begin{array}{c}\text { Crystalline/ } \\
\text { Amorphous State }\end{array}$ & Experimental Conditions & Adsorption Capacity (mg/g) & Adsorption Efficiency (\%) & Selectivity Series & References \\
\hline BFS & - & $\begin{array}{c}\mathrm{C}_{\mathrm{o}}=10^{-4}-10^{-3} \mathrm{~mol} / \mathrm{L} \mathrm{Me}{ }^{2+*} ; \mathrm{pH}=4.0-4.2 ; \\
\mathrm{T}=25^{\circ} \mathrm{C} ; d_{p}=0.063-0.25 \mathrm{~mm} ; \\
\text { Phase ratio }=1 \mathrm{~g} / \mathrm{L} \mathrm{BFS}\end{array}$ & $\begin{array}{l}2.1 \times 10^{-3} \mathrm{~mol} / \mathrm{g} \mathrm{Cu}^{2+} \\
0.95 \times 10^{-3} \mathrm{~mol} / \mathrm{g} \mathrm{Ni}^{2+} \\
1.58 \times 10^{-3} \mathrm{~mol} / \mathrm{g} \mathrm{Zn}^{2+}\end{array}$ & $\begin{array}{l}100 \% \mathrm{Cu}^{2+} \\
100 \% \mathrm{Zn}^{2+} \\
72 \% \mathrm{Ni}^{2+}\end{array}$ & $\mathrm{Cu}^{2+}>\mathrm{Zn}^{2+}>\mathrm{Ni}^{2+}$ & [70] \\
\hline BFS & - & $\begin{array}{c}\mathrm{C}_{\mathrm{o}}=13-93 \mathrm{mg} / \mathrm{L} \mathrm{Pb} b^{2+} ; \mathrm{pH}=2-9 ; \\
\mathrm{T}=25^{\circ} \mathrm{C} ; d_{p}=0.1-5 \mathrm{~mm} \\
\text { Phase ratio }=1 \mathrm{~g} / \mathrm{L} \mathrm{BFS}\end{array}$ & $\sim 37 \mathrm{mg} / \mathrm{g} \mathrm{Pb}{ }^{2+}$ & $98 \% \mathrm{~Pb}^{2+}$ & & [42] \\
\hline BFS & Crystalline & $\begin{array}{c}\mathrm{C}_{\mathrm{o}}=10^{-3} \mathrm{~mol} / \mathrm{L} \mathrm{Me} \mathrm{Me}^{2+}(\mathrm{Cu}, \mathrm{Ni} \text { and } \mathrm{Zn}) ; \mathrm{pH}=4 ; \\
\mathrm{T}=25^{\circ} \mathrm{C} ; d_{p}=0.1-5 \mathrm{~mm} ; \\
\text { Phase ratio }=1 \mathrm{~g} / \mathrm{L} \mathrm{BFS}\end{array}$ & - & $94-100 \% \mathrm{Me}^{2+}(\mathrm{Cu}, \mathrm{Ni}$ and $\mathrm{Zn})$ & $\mathrm{Cu}^{2+}>\mathrm{Ni}^{2+}>\mathrm{Zn}^{2+}$ & [19] \\
\hline BFS & Mainly amorphous & $\begin{array}{l}\mathrm{C}_{\mathrm{o}}=16.5 \mathrm{mg} / \mathrm{L} \mathrm{Cu}{ }^{2+} ; \mathrm{pH}=4 \\
\mathrm{~T}=25^{\circ} \mathrm{C} ; d_{p}<0.25 \mathrm{~mm} ; \\
\text { Phase ratio }=1 \mathrm{~g} / \mathrm{L} \mathrm{BFS}\end{array}$ & $16.52 \mathrm{mg} / \mathrm{g} \mathrm{Cu}^{2+}$ & - & - & [15] \\
\hline EAF & Crystalline & $\begin{array}{c}\mathrm{C}_{\mathrm{o}}=100-1000 \mathrm{mg} / \mathrm{L} \mathrm{Pb}^{2+} \text { and } \mathrm{Cu}^{2+} ; \mathrm{pH}=4.5 ; \\
\mathrm{T}=20-40^{\circ} \mathrm{C} ; d_{p}=0.05-0.63 \mathrm{~mm} ; \\
\text { Phase ratio }=10 \mathrm{~g} / \mathrm{L} \mathrm{EAF}\end{array}$ & $\begin{array}{l}37.04 \mathrm{mg} / \mathrm{g} \mathrm{Pb}^{2+} \\
39.22 \mathrm{mg} / \mathrm{g} \mathrm{Cu}^{2+}\end{array}$ & - & $\mathrm{Cu}^{2+}>\mathrm{Pb}^{2+}$ & [67] \\
\hline Ironmaking slag & - & $\begin{array}{c}\mathrm{C}_{\mathrm{o}}=15-170 \mathrm{mg} / \mathrm{L} \mathrm{Pb}^{2+} \text { and } \mathrm{Cu}^{2+} ; \mathrm{pH}=5.5 ; \\
\mathrm{T}=18^{\circ} \mathrm{C} ; \bar{d}_{\mathrm{p}}=24.1-24.5 \mu \mathrm{m} \\
\text { Phase ratio }=2 \mathrm{~g} / \mathrm{L} \text { slag; }\end{array}$ & $\begin{array}{l}95.34 \mathrm{mg} / \mathrm{g} \mathrm{Pb}^{2+} \\
88.50 \mathrm{mg} / \mathrm{g} \mathrm{Cu}^{2+}\end{array}$ & - & $\mathrm{Cu}^{2+}>\mathrm{Pb}^{2+}$ & [71] \\
\hline Steelmaking slag & - & $\begin{array}{c}\mathrm{C}_{\mathrm{o}}=25 \mathrm{mg} / \mathrm{L} \mathrm{Cr}^{3+}=\mathrm{Zn}^{2+}=\mathrm{Cu}^{2+}=\mathrm{Pb}^{2+} \\
\mathrm{pH}=1.3-7.5 ; \mathrm{T}=-; d_{p}=420-177 \mu \mathrm{m} ; \\
\text { Phase ratio = } 10 \mathrm{~g} / \mathrm{L} \text { slag; Time }=1 \mathrm{~h}\end{array}$ & - & $\begin{array}{l}97.87 \% \mathrm{Cr}^{3+} ; 96.79 \% \mathrm{Zn}^{2+} \\
85.41 \% \mathrm{Cu}^{2+} \\
82.08 \% \mathrm{~Pb}^{2+}\end{array}$ & $\mathrm{Cr}^{3+}>\mathrm{Zn}^{2+}>\mathrm{Cu}^{2+}>\mathrm{Pb}^{2+}$ & [89] \\
\hline EAF (SG slag) & Crystalline & $\begin{array}{c}\mathrm{C}_{\mathrm{o}}=0.2-3.2 \mathrm{mmol} / \mathrm{L} \mathrm{Me}^{2+} ; \mathrm{pH}=5 \\
\mathrm{~T}=25^{\circ} \mathrm{C} ; d_{p}=45-90 \mu \mathrm{m} \\
\text { Phase ratio }=10 \mathrm{~g} / \mathrm{L} \text { slag }\end{array}$ & $\begin{array}{l}0.156 \mathrm{mmol} / \mathrm{g} \mathrm{Cu}^{2+} ; \\
0.166 \mathrm{mmol} / \mathrm{g} \mathrm{Cd}^{2+} ; \\
0.148 \mathrm{mmol} / \mathrm{g} \mathrm{Zn}^{2+} ; \\
0.145 \mathrm{mmol} / \mathrm{g} \mathrm{Pb}^{2+}\end{array}$ & - & $\mathrm{Cd}^{2+}>\mathrm{Cu}^{2+}>\mathrm{Zn}^{2+}>\mathrm{Pb}^{2+}$ & [5] \\
\hline EAF & - & $\begin{array}{c}\mathrm{C}_{\mathrm{o}}=6 \mathrm{mg} / \mathrm{L} \text { Arsenic; } \mathrm{pH}=10 \\
\mathrm{~T}=25^{\circ} \mathrm{C} ; d p=-; \\
\text { Phase ratio }=7 \mathrm{~g} / \mathrm{L} \text { EAF }\end{array}$ & $1.99 \mathrm{mg} / \mathrm{g} \mathrm{As}$ & $100 \%$ As & - & [6] \\
\hline BOF & Crystalline & $\begin{array}{c}\mathrm{C}_{\mathrm{o}}=1000-4000 \mathrm{mg} / \mathrm{L} \mathrm{Cu} \mathrm{Cu}^{2+} ; \mathrm{pH}=3-5 ; \\
\mathrm{T}=20^{\circ} \mathrm{C} ; d_{p}<0.6 \mathrm{~mm} ; \\
\text { Phase ratio }=5 \mathrm{~g} / \mathrm{L} \mathrm{BOF}\end{array}$ & $245.2 \mathrm{mg} / \mathrm{g} \mathrm{Cu}^{2+}$ & $99.9 \% \mathrm{Cu}^{2+}($ from $1000 \mathrm{mg} / \mathrm{L})$ & - & [62] \\
\hline BOF & - & $\begin{array}{c}\mathrm{C}_{\mathrm{o}}=1000 \mathrm{mg} / \mathrm{L} \mathrm{Fe} 2^{+} ; 5000 \mathrm{mg} / \mathrm{L} \mathrm{SO} O_{4}^{2-} \\
\mathrm{pH}=2.5 ; \mathrm{T}=25^{\circ} \mathrm{C} ; d_{p}<75 \mu \mathrm{m} ; \\
\text { Phase ratio }=20-140 \mathrm{~g} / \mathrm{L} \text { BOF }(100 \mathrm{~g} / \mathrm{L} \text { optimum })\end{array}$ & - & $\begin{array}{l}99.7 \% \mathrm{Fe}^{2+} \\
75 \% \mathrm{SO}_{4}^{2-}\end{array}$ & - & [90] \\
\hline Steelmaking slag & Crystalline & $\begin{array}{c}1-100 \mathrm{mg} / \mathrm{L} \mathrm{Co}^{2+} \& \mathrm{Ni}^{2+} ; 2-170 \mathrm{mg} / \mathrm{L} \mathrm{Cd}^{2+} \\
\text { 3.5-350 mg/L Pb } \\
\text { Phase ratio }=5 \mathrm{~g} / \mathrm{L} \text { slag }\end{array}$ & $\begin{array}{l}0.04 \mathrm{mmol} / \mathrm{g} \mathrm{Co}^{2+} ; \\
0.05 \mathrm{mmol} / \mathrm{g} \mathrm{Ni}^{2+} ; \\
0.04 \mathrm{mmol} / \mathrm{g} \mathrm{Cd}^{2+} ; \\
0.08 \mathrm{mmol} / \mathrm{g} \mathrm{Pb}^{2+} ;\end{array}$ & - & $\mathrm{Pb}^{2+}>\mathrm{Ni}^{2+}>\mathrm{Cd}^{2+}>\mathrm{Co}^{2+}$ & [91] \\
\hline
\end{tabular}


Table 6. Cont

\begin{tabular}{|c|c|c|c|c|c|c|}
\hline Slag Type & $\begin{array}{c}\text { Crystalline/ } \\
\text { Amorphous State }\end{array}$ & Experimental Conditions & Adsorption Capacity (mg/g) & Adsorption Efficiency (\%) & Selectivity Series & References \\
\hline Steelmaking slag & - & $\begin{array}{c}\mathrm{C}_{\mathrm{o}}=100 \mathrm{mg} / \mathrm{L} \mathrm{Mn}^{2+} ; \mathrm{pH}=3-8(6 \text { optimum }) ; \\
\mathrm{T}=25^{\circ} \mathrm{C} ; d_{p}=1 \mathrm{~mm} ; \\
\text { Phase ratio }=0.1-2 \mathrm{~g} / \mathrm{L} \text { slag }\end{array}$ & $\sim 1.5 \mathrm{mg} / \mathrm{g} \mathrm{Mn}^{2+}$ & $>95 \% \mathrm{Mn}^{2+}$ & - & [73] \\
\hline BOF & Crystalline & $\begin{array}{c}75-150 \mathrm{mg} / \mathrm{L} \mathrm{Cr}{ }^{6+} ; \mathrm{pH}=-; \mathrm{T}=25^{\circ} \mathrm{C} ; \\
d_{p}<0.180 \mathrm{~mm} ; \text { Phase ratio }=10 \mathrm{~g} / \mathrm{L} \text { BOF }\end{array}$ & $11.9 \mathrm{mg} / \mathrm{g} \mathrm{Cr}^{6+}$ & $\begin{array}{l}100 \% \mathrm{Cr}^{6+}(\leq 100 \mathrm{mg} / \mathrm{L}) ; \\
64.8 \% \mathrm{Cr}^{6+}(\sim 150 \mathrm{mg} / \mathrm{L})\end{array}$ & - & [85] \\
\hline BOF & Crystalline & $\begin{array}{c}5-100 \mathrm{mg} / \mathrm{L} \text { Vanadium; } \mathrm{pH}=1-11 ; \mathrm{T}=25^{\circ} \mathrm{C} ; \\
\quad d_{p}<0.15 \mathrm{~mm} ; \text { Phase ratio }=50 \mathrm{~g} / \mathrm{L} \text { BOF }\end{array}$ & $5.45 \mathrm{mg} / \mathrm{g}$ & $97.1 \% \mathrm{~V}(100 \mathrm{mg} / \mathrm{L} ; \mathrm{pH}=6$ & - & [84] \\
\hline Steelmaking slag & Crystalline & $\begin{array}{c}0.05-1 \mathrm{mg} / \mathrm{L} \text { Phenanthrene; } 3-5 \mathrm{mg} / \mathrm{L} \text { Naphthalene; } \\
\mathrm{pH}=3-11 ; \mathrm{T}=25^{\circ} \mathrm{C} ; d_{p}<150 \mu \mathrm{m} ; \\
\text { Phase ratio }=1-10 \mathrm{~g} / \mathrm{L} \mathrm{slag}\end{array}$ & $\begin{array}{l}0.043 \mathrm{mg} / \mathrm{g} \text { phenanthrene; } \\
0.041 \mathrm{mg} / \mathrm{g} \text { naphthalene }\end{array}$ & - & - & [64] \\
\hline BFS & $\begin{array}{l}\text { More amorphous } \\
\text { than crystalline }\end{array}$ & $\begin{array}{c}5 \mathrm{mg} / \mathrm{L} \mathrm{Pb}=\mathrm{Cu}=\mathrm{Cd}=\mathrm{Cr}=\mathrm{Zn} ; \mathrm{pH}=2-9 ; \\
\mathrm{T}=25^{\circ} \mathrm{C} ; d_{p}=150-300 \mu \mathrm{m} ; \text { Phase ratio }=5 \mathrm{~g} / \mathrm{L} \text { BFS }\end{array}$ & $\begin{array}{l}5.05 \mathrm{mg} / \mathrm{g} \mathrm{Cd} \\
4.83 \mathrm{mg} / \mathrm{g} \mathrm{Cr} \\
5.22 \mathrm{mg} / \mathrm{g} \mathrm{Cu} \\
4.93 \mathrm{mg} / \mathrm{g} \mathrm{Pb} \\
4.26 \mathrm{mg} / \mathrm{g} \mathrm{Zn}\end{array}$ & $\begin{array}{l}\sim 88-95 \% \text { for all metal ions } \\
(5 \mathrm{mg} / \mathrm{L} ; \mathrm{pH}=6.5)\end{array}$ & $\mathrm{Pb}, \mathrm{Cu}, \mathrm{Cd}>\mathrm{Cr}>\mathrm{Zn}$ & [92] \\
\hline
\end{tabular}

${ }^{*} \mathrm{C}_{\mathrm{i}}=$ initial metal ion concentration; ${ }^{\#} \mathrm{BFS}=$ blast furnace slag; $\mathrm{BOF}=$ basic oxygen furnace slag; $\mathrm{EAF}=$ electric arc furnace slag. 


\subsection{Parameters that Affect the Adsorption Capacity of Slags}

The adsorption performance depends on, among other factors, the physicochemical and surface properties of slags. Moreover, the cations and anions in solutions have different affinities for various functional groups on the slag surfaces. In addition, the competitive adsorption of cations is a complex phenomenon that is dependent on the surface interactions and solute concentrations. It is well known that several factors, including solution $\mathrm{pH}$, initial solute concentration, speciation of cations in solution and surface charge, affect the adsorption of cations and anions from solution. Other factors such as adsorbent loading ratio and adsorbent particle size also play a crucial role. Thus, this section discusses in detail the effect of selected parameters on the adsorption performance of slags under different experimental conditions.

\subsubsection{Effect of Solution $\mathrm{pH}$}

The solution $\mathrm{pH}$ has a significant effect on the rate and mechanism of the adsorption of metal ions onto slags. Findings from several studies have clearly demonstrated that the efficiency of the adsorption of metal ions increases with increase in $\mathrm{pH}[3,42,59,61,62,70,71,75-77,83,93-95]$. In addition, the $\mathrm{pH}$ of a solution is intricately linked to the point of zero charge (PZC) of the adsorbent surfaces, and hence the $\mathrm{pH}$ of the solution relative to the PZC affects the adsorption of cations and/or anions $[3,61,94,95]$. Technically, the PZC is defined as the $\mathrm{pH}$ value at which the surface of a substance has a net neutral charge $[3,61,94]$. The solution $\mathrm{pH}$ makes solid surfaces neutral at $\mathrm{pH}$ values equal to the PZC and positively charged below the $\mathrm{PZC}$, while the solid surfaces become negatively charged at $\mathrm{pH}$ values greater than the PZC [95]. This implies that in the low $\mathrm{pH}$ region, the adsorption of positively charged ions below PZC may involve competitive effects of the hydrogen ion adsorption, thereby suppressing the adsorption of metal ions (Equation (14)). In this instance, the slag surfaces tend to have a large positive charge density, which results in electrostatic repulsion between metal ions and surface charges [61,94].

$$
\overline{(\equiv S O)_{2}^{-}} \mathrm{Ca}^{2+}+\mathrm{Me}^{2+}+\mathrm{H}^{+} \rightarrow \overline{(\equiv S O)_{2}} \mathrm{H}^{+}+\mathrm{Me}^{2+}+\mathrm{Ca}^{2+}
$$

where overbar $=$ adsorbent $($ solid $)$ phase and $(\equiv S O)=$ deprotonated surface site $(\mathrm{S}=\mathrm{Al}$ or $\mathrm{Si})$.

Though the position of the PZC defines the affinity of the surface to the ionic species, the extent of adsorption may also either increase or decrease depending on solid surface characteristics, saturation, and oxidation state and/or speciation of metal ions, electrostatic forces, adsorbent net surface charge density and adsorption site density $[3,61,71,93,95,96]$.

The effect of solution $\mathrm{pH}$ on the adsorption behaviour of metal ions by ironmaking and steelmaking slags has been elucidated in several studies. In earlier studies, Huang and Rhoads [93] proposed that adsorption of $\mathrm{Zn}^{2+}$ on several silicate-based materials is only effective at $\mathrm{pH}>7$ due to the competitive effect of $\mathrm{H}^{+}$ions at low $\mathrm{pH}$. A study by Zahar et al. [73] also confirmed that the adsorption efficiency of $\mathrm{Mn}^{2+}$ ions by steelmaking slag increased with an increase in $\mathrm{pH}(3-8)$, with the optimum $\mathrm{pH}$ being 6 .

Dimitrova and Mehandgiev [42] studied the effect of initial $\mathrm{pH}$ on $\mathrm{Pb}^{2+}$ ion adsorption from a solution of $92.55 \mathrm{mg} \mathrm{L}^{-1} \mathrm{~Pb}^{2+}$ ions using g-BFS $\left(d_{p} \leq 0.8 \mathrm{~mm}, 1 \mathrm{~g} \mathrm{~L}^{-1}\right)$. The results showed a $98 \% \mathrm{~Pb}^{2+}$ adsorption efficiency at $\mathrm{pH}>6.0$. The adsorption profile followed an S-shaped graphical relation that is typical for inorganic adsorbents. The adsorption increased with increase in initial $\mathrm{pH}$, and the occurrence of increase in equilibrium $\mathrm{pH}$ was attributed to the hydrolysis and ion-exchange interaction of $\mathrm{H}^{+}$and the $\mathrm{Ca}^{2+}$ in the glass phases of the slag (Equation (15)). Dimitrova and Mehandgiev [42] interpreted the mechanism of $\mathrm{Pb}^{2+}$ adsorption on the assumption that acid neutralisation and adsorption were dominant at $\mathrm{pH}<5.5$, while the precipitation of $\mathrm{Pb}^{2+}$ complexes such as $\mathrm{PbOH}^{+}$and $\mathrm{Pb}_{3}\left(\mathrm{OH}_{4}^{2+}\right)$ occurred at $\mathrm{pH}>5$.5. In similar studies, Dimitrova and Mehandgiev [19] evaluated single-component adsorption of $\mathrm{Cu}^{2+}, \mathrm{Zn}^{2+}$ and $\mathrm{Ni}^{2+}$ ions by BFS and obtained over $94 \%$ metal removal in all cases. 
The findings from this study also confirmed that the adsorption of metal ions on slags was accompanied by a gradual increase in equilibrium $\mathrm{pH}$ due to the hydrolysis of the slag.

$$
=\mathrm{SiOCa}+2 \mathrm{HOH} \rightarrow \mathrm{SiOH}+\mathrm{Ca}^{2+}+2 \mathrm{OH}^{-}
$$

where $=\mathrm{SiOCa}$ is the adsorbent site showing $\mathrm{Ca}$ and bonds.

Feng et al. [71] investigated the effect of PZC values for ironmaking and steelmaking slags. The results showed low adsorptivity of $\mathrm{Cu}^{2+}$ and $\mathrm{Pb}^{2+}$ ions at $\mathrm{pH}$ values below the $\mathrm{PZC}$ as a result of electrostatic repulsion between metal ions and the positively charged slag surfaces. A similar trend was observed for steelmaking slag at pH 3.2. Based on electrophoretic measurements, Feng et al. [71] also established that the equilibrium $\mathrm{pH}$ and metal adsorption were controlled by the slag surface charges. However, Feng et al. [71] also attributed the high metal adsorption at higher $\mathrm{pH}$ values to the possibility of precipitation of metal ions.

Kim et al. [83] investigated the adsorption of $\mathrm{Cu}^{2+}$ ions (10-5000 $\mathrm{mg} \mathrm{L}^{-1}$ at $100 \mathrm{~g} \mathrm{~L}^{-1}$ slag dose) using three types of steelmaking slags (unnormalised composition: $\mathrm{Slag} 1=65.8 \% \mathrm{CaO}, 10.8 \mathrm{wt}$. $\% \mathrm{SiO}_{2}$, 1.6 wt. $\% \mathrm{Al}_{2} \mathrm{O}_{3}, 3.5$ wt. $\% \mathrm{MgO}, 13.4$ wt. $\%$ T-Fe; Slag $2=44.6$ wt. $\% \mathrm{CaO}, 6.1$ wt. $\% \mathrm{SiO}_{2}$, 3.9 wt. $\% \mathrm{Al}_{2} \mathrm{O}_{3}, 2.7$ wt. $\% \mathrm{MgO}, 1.0$ wt. $\% \mathrm{MnO}, 28.3$ wt. $\% \mathrm{~T}-\mathrm{Fe}$; Slag $3=54.2$ wt. \% CaO, 23.3 wt. $\% \mathrm{SiO}_{2}, 7.3$ wt. $\% \mathrm{Al}_{2} \mathrm{O}_{3}, 5.1$ wt. $\% \mathrm{MgO}, 2.0 \mathrm{wt}$. \% T-Fe). The adsorption efficiency $\left(Q_{\max } \approx 300 \mathrm{mg} \mathrm{g}^{-1}\right)$ increased with increase in solution $\mathrm{pH}$ for all slags, which, in turn, was strongly related to the lime content of the slags. The results indicated that the removal of $\mathrm{Cu}^{2+}$ ions occurred via precipitation of hydroxides at high equilibrium $\mathrm{pH}$. Similarly, Huifen et al. [97] also explored the multi-solute adsorption of $\mathrm{Cu}^{2+}, \mathrm{Zn}^{2+} \mathrm{Cd}^{2+}$ and $\mathrm{Pb}^{2+}$ ions by steelmaking slag as a function of solution $\mathrm{pH}$ (at $25 \mathrm{mg} \mathrm{L}^{-1} \mathrm{Me}^{2+}, 30 \mathrm{~g} \mathrm{~L}^{-1}$ slag). The adsorption efficiency increased with increase in solution $\mathrm{pH}$, which was attributed to ion exchange below $\mathrm{pH} 3.5$ and hydroxide precipitation above $\mathrm{pH} 3.5$ as a result of slag hydrolysis. These findings also concurred with earlier studies by Dimitrova [70] and Dimitrova and Mehandgiev [19,42] finding that the removal of metal ions was negligible below $\mathrm{pH} 5$ due to the competitive effect of hydrogen protons.

Xue et al. [77] applied speciation diagrams and an extended constant-capacitance surface complexation model to determine the $\mathrm{pH}$-dependence and mechanism of adsorption of $\mathrm{Cu}^{2+}, \mathrm{Cd}^{2+}$, $\mathrm{Pb}^{2+}$ and $\mathrm{Zn}^{2+}$ ions on BOF slag in both single and multicomponent systems. The value of $\mathrm{pH}_{50}$, defined as the $\mathrm{pH}$ at which $50 \%$ of the adsorption takes place, was found to follow the sequence $\mathrm{Zn}>$ $\mathrm{Cu}>\mathrm{Pb}>\mathrm{Cd}$ in single-solute systems, and $\mathrm{Pb}>\mathrm{Cu}>\mathrm{Zn}>\mathrm{Cd}$ in multi-solute systems. Xue et al. [77] proposed that, for all ions, adsorption initially occurred on permanent charge sites at low $\mathrm{pH}$ via an ion-exchange process, followed by adsorption at variable charge sites to form complexes at high $\mathrm{pH}$ values. The shift in the adsorption mechanism largely depended on the type of cations and $\mathrm{pH}$. Furthermore, the differences in surface speciation reflected the fact that metal ions that readily formed hydrolysis products adsorbed via complex formation on variable charged sites. The observed order of preference in single-solute systems was attributed to the tendency of cations to form hydrolysis products. In multi-solute systems, the preference for $\mathrm{Pb}^{2+}$ sorption was attributed to the smaller hydrated cationic radius of $\mathrm{Pb}^{2+}$ ions as well as to the higher electronegativity of $\mathrm{Pb}$ for electrostatic and inner surface complexation reactions (discussed in Section 4.3.5).

Liu et al. [89] investigated the adsorption of $\mathrm{Cr}^{3+}$ ions by steelmaking slag $\left(100 \mathrm{mg} \mathrm{L}^{-1} \mathrm{Cr}^{3+}\right.$, $30 \mathrm{~g} \mathrm{~L}^{-1}$ slag, and composition 38.83 wt. \% $\mathrm{Fe}_{2} \mathrm{O}_{3}, 32.73$ wt. \% $\mathrm{CaO}, 10$ wt. \% $\mathrm{MgO}, 3.29$ wt. \% $\mathrm{MnO}$, 12.33 wt. $\% \mathrm{SiO}_{2}, 0.18$ wt. $\% \mathrm{Al}_{2} \mathrm{O}_{3}$, and 0.2 wt. $\% \mathrm{Cr}_{2} \mathrm{O}_{7}$ ). Complete adsorption was attained in the $\mathrm{pH}$ range 1.3-7.5. However, other studies have reported that the removal of $\mathrm{Cr}^{3+}$ was only possible at $\mathrm{pH}<5[98,99]$. From the Pourbaix diagrams, $\mathrm{Cr}^{3+}$ and $\mathrm{CrOH}^{2+}$ species are the dominant species in the $\mathrm{pH}$ range $2-4$, while increasing the $\mathrm{pH}$ over 5 would result in the formation of soluble hydroxyl complexes such as $\mathrm{Cr}(\mathrm{OH})_{3}$ [98-100]. In a similar study, Han et al. [85] also proposed that acidic conditions favoured the removal of $\mathrm{Cr}^{6+}$ ions by BOF slag. In both cases, the specific role of acid was to neutralise any $\mathrm{OH}^{-}$ions generated from the hydrolysis of slag, thereby reducing the formation of soluble $\mathrm{Cr}(\mathrm{OH})_{3}$ species. Most importantly, the chemical reaction between the acid and the $\mathrm{FeO}$ and 
$\mathrm{Fe}_{3} \mathrm{O}_{4}$ phases in slag released $\mathrm{Fe}^{2+}$ ions that were responsible for the removal of $\mathrm{Cr}^{6+}$ through a redox process [85,89].

In a recent study, Gao et al. [84] proposed that the efficiency of vanadium removal from soil washing effluent by BOF slag $\left(100 \mathrm{mg} \mathrm{L}^{-1} \mathrm{~V}, d_{p}<0.15 \mathrm{~mm} ; 50 \mathrm{~g} \mathrm{~L}^{-1}\right.$ slag; $\left.1<\mathrm{pH}<11\right)$ was not affected by the initial $\mathrm{pH}$ of the solution. The lack of $\mathrm{pH}$-dependence on the removal of vanadium ions can be attributed to the high initial $\mathrm{pH}$ of slag $(\mathrm{pH}=12.47)$ as a result of the high content of basic oxides (33.66 wt. \% CaO, 30.87 wt. $\mathrm{Fe}_{2} \mathrm{O}_{3}, 6.06$ wt. \% MgO, and 2.60 wt. \% MnO). Furthermore, according to Gao et al. [84], vanadium exists as anions in solution and, consequently, was unlikely to form hydroxyl precipitates with the $\mathrm{OH}^{-}$or suffer from antagonistic competitive effects of $\mathrm{H}^{+}$or other cations on slag surfaces.

\subsubsection{Effect of Initial Concentration of Metal Ions}

The amount of ions adsorbed is a function of the initial concentration of the adsorbate $[69,70,77,101,102]$. According to Weber and Morris [102], the initial rate of adsorption is directly proportional to the solute concentration in processes that are controlled by site adsorption. Increasing the initial adsorbate concentration thus increases the driving force to overcome the resistance to mass transfer of metal ions between the aqueous and the solid phases [102]. Results from several other studies have also confirmed the effect of initial concentration of adsorbates on the performance of granular slag adsorbents $[69,70,73,77,85]$. In particular, Xue et al. [77] observed an increase in the amounts of $\mathrm{Cu}^{2+}$, $\mathrm{Pb}^{2+}, \mathrm{Zn}^{2+}$ and $\mathrm{Cd}^{2+}$ ions adsorbed onto BOF slag with increases in solute concentration. Similarly, Liu et al. [69] also observed that the adsorption efficiency of $\mathrm{Pb}^{2+}$ ions increased with increase in initial concentration. Since external diffusion was considered to be rate-controlling, the higher solute concentrations provided the driving force and reduced the resistance to external diffusion of the adsorbates $[69,70,77]$.

It must be noted that other studies found contrasting results. For example, Zahar et al. [73] observed that the adsorption efficiency of $\mathrm{Mn}^{2+}$ by steelmaking slag decreased with increase in initial concentration. A similar trend was also observed by Han et al. [85] based on the adsorption of $\mathrm{Cr}^{6+}$ ions by BOF slag from solutions containing $75-150 \mathrm{mg} \mathrm{L}^{-1} \mathrm{Cr}^{6+}$. Complete adsorption was achieved in adsorption systems with initial concentrations of up to $100 \mathrm{mg} \mathrm{L}^{-1} \mathrm{Cr}^{6+}$, and decreased to $65 \%$ when the solute concentration was increased to $150 \mathrm{mg} \mathrm{L}^{-1} \mathrm{Cr}^{6+}$ [85]. Similarly, Gao et al. [84] reported a decrease in the adsorption efficiency of vanadium with an increase in initial concentration. A study by Dimitrova [70] using ungranulated blast furnace slag also found that the adsorption efficiency was limited to $60 \% \mathrm{Cu}^{2+}, 46 \% \mathrm{Zn}^{2+}$ and $32 \% \mathrm{Ni}^{2+}$ in relatively high solute solutions $\left(C_{0}=3.5 \times 10^{-3} \mathrm{M}\right)$, whereas complete adsorption of $\mathrm{Cu}^{2+}$ and $\mathrm{Zn}^{2+}$, and $72 \%$ of $\mathrm{Ni}^{2+}$ was achieved from dilute solutions $\left(C_{0}=5 \times 10^{-4} \mathrm{M}\right)$. Dimitrova [70] proposed the colloid-chemical interactions of solutes, both in solution and on the surfaces of slag, to be the driving force for adsorption.

\subsubsection{Effect of slag loading ratio}

In general, higher adsorbent loading ratios result in higher adsorption efficiencies. Increasing the adsorbent loading ratio increases the sorptive surface area and the number of available active binding sites. The relationship between the adsorbent mass and adsorption efficiency has been confirmed in many studies $[42,69,85,89,97]$. Dimitrova and Mehandgiev [42] proposed that the adsorption efficiency of metal ions increased with increase in g-BFS adsorbent/sorbate ratio at any given initial metal ion concentration. The researchers proposed that the adsorption of $\mathrm{Pb}^{2+}$ ions occurred via an ion-exchange mechanism through which the calcium dissolution from slags created free adsorption sites for $\mathrm{Pb}^{2+}$ ions. Thus, increasing the adsorbent loading ratio at fixed adsorption volume increased the amount of adsorption sites and equilibrium $\mathrm{pH}$ conditions favourable for $\mathrm{Pb}^{2+}$ adsorption.

Huifen et al. [97] explored the adsorption of a multi-solute system of $\mathrm{Cu}^{2+}, \mathrm{Zn}^{2+} \mathrm{Cd}^{2+}$ and $\mathrm{Pb}^{2+}$ ions $\left(\mathrm{Cu}^{2+}=\mathrm{Zn}^{2+}=\mathrm{Cd}^{2+}=\mathrm{Pb}^{2+}=25 \mathrm{mg} \mathrm{L} \mathrm{L}^{-1}\right)$ by steelmaking slag as a function of the mass of slag. Similarly, the adsorption efficiency increased with increase in mass of slag. In a similar study, 
Liu et al. [89] also observed that the efficiency of $\mathrm{Cr}^{3+}$ ion adsorption by steelmaking slag $\left(100 \mathrm{mg} \mathrm{L}^{-1}\right.$ $\mathrm{Cr}^{3+}, 30 \mathrm{~g} \mathrm{~L}^{-1} \mathrm{slag}$ ) increased with increase in solid/liquid phase ratio. Similarly, Han et al. [85] observed an increase in adsorption efficiency of $\mathrm{Cr}^{6+}$ ions and fast kinetics in the initial stages of the adsorption process with increase in the mass of $\mathrm{BOF}$ slag. Since the removal of $\mathrm{Cr}^{6+}$ ions was proposed to occur via a redox process involving $\mathrm{Fe}^{2+}$ ions, increasing the mass of slag increased the concentration of solubilised $\mathrm{Fe}^{2+}$ ions available for the redox reaction [85]. In a more recent study, Gao et al. [84] also confirmed an increase in the adsorption of vanadium ions when the BOF slag loading ratio was varied between 0.5 and $2.5 \mathrm{~g} \mathrm{~L}^{-1}$.

The slag loading ratio critically affects the adsorption capacity and, subsequently, the design of adsorption processes themselves. Indeed, the amount of adsorbent affects the design size of the adsorption vessel and, ultimately, the overall costs of the adsorption process. Since ironmaking and steelmaking slags are typically associated with limited adsorption capacities, large quantities of slag would then be required to attain reasonable effluent discharge standards. In other words, the low adsorption capacity dictates the use of higher slag loading ratios, which in essence, creates challenges in terms of the reactor size and the overall environmental footprint of the treatment plants. Thus, the economic application of ironmaking and steelmaking slags as low-cost and sustainable adsorbents depends on increasing their adsorption capacities. Section 5 highlights some of the promising approaches to enhance the adsorptive capacities of slags.

\subsubsection{Effect of Particle Size}

Adsorption is a surface heterogeneous reaction involving pore and intraparticle diffusion. In essence, the effective mass transfer kinetics of heterogeneous systems depend on particle size distribution, specific surface area and particle porosity, among other factors [3,103-106]. This means that adsorbent particle sizes play a significant role on the adsorption capacity and rate of adsorption by granular, non-porous adsorbents. The surface area increases with a decrease in particle size and this, in turn, increases adsorption opportunity on the outer surfaces of slag materials [3]. Findings from previous studies have also corroborated the effect of particle sizes of ironmaking and steelmaking slags on the removal of metal ions from solution. For example, Liu et al. [89] observed an increase in the adsorption efficiency of $\mathrm{Cr}^{3+}$ ions $\left(C_{0}=100 \mathrm{mg} \mathrm{L}^{-1} \mathrm{Cr}^{3+} ; 30 \mathrm{~g} \mathrm{~L}^{-1}\right.$ slag) with a decrease in the particle sizes of steelmaking slag. The initially high rate of $\mathrm{Cr}^{3+}$ ion adsorption was attributed to the availability of large surface area at the start of the adsorption process. However, as adsorption progressed, surface adsorption sites become exhausted and the overall rate of adsorption thus became controlled by the intraparticle or pore diffusion. Liu et al. [69] also observed that the efficiency of adsorption of $\mathrm{Pb}^{2+}$ ions (100 mg L $\mathrm{mg}^{-1} \mathrm{~Pb}^{2+}$ initial concentration and $30 \mathrm{~g} \mathrm{~L}^{-1}$ slag loading ratio) increased from $46.5 \%$ to $96 \%$ when the particle size range was reduced from $25-18 \mathrm{~mm}$ to $0.125-0.09 \mathrm{~mm}$, beyond which further reduction in particle size had no significant effect on the adsorption efficiency. Han et al. [85] observed a decrease in $\mathrm{Cr}^{6+}$ adsorption by BOF slag when particle size was increased beyond $0.045-0.058 \mathrm{~mm}$. Similarly, Gao et al. [84] also observed an increase in the adsorption efficiency of vanadium from soil-washing effluent when the BOF slag particle size was decreased from $0.15-2 \mathrm{~mm}$ to $<0.15 \mathrm{~mm}$.

Based on findings from these and several other studies, reducing the particle sizes increases the surface area for adsorption, and thus enhances the opportunity for adsorption of metal ions through pore and intraparticle diffusion. It is also clear that the diffusional resistance to mass transfer is greater for larger particles, due to possible blockage of surface sites, longer diffusional path lengths, mass transfer resistance and shorter contact time, among other factors $[69,89,103,105]$. Nevertheless, the chemical and geometric phase heterogeneity of slags significantly affects the elaborate understanding of mechanism of adsorption. For example, Dimitrova and Mehandgiev [42] could not establish any mathematical relationship between the adsorption of $\mathrm{Pb}^{2+}$ ions on $\mathrm{BFS}$ and surface area with decrease in the particle size diameter of slag. 


\subsubsection{Competitive Multi-Solute Adsorption}

Multi-solute systems are the typical state of pollutants commonly associated with industrial effluents and wastewaters. However, multi-solute adsorption may be complicated by the effects of interaction and competition amongst the solutes on adsorbent sites. Several studies highlighted so far have proposed the adsorption capacities and mechanisms of multi-solute adsorption to involve ion exchange, electrostatic interaction and complex adsorption. However, the relative contribution of these mechanistic steps is not clear, mostly due to the complexity imposed by the heterogeneity of the slags [22,23] and/or the complex synergistic or antagonistic interactive effects of metal ions in multi-solute systems [77,100,107-109]. In addition, interpretations of multi-solute adsorption data appear to be inconsistent, and the mechanisms are yet to be clearly understood.

For typical cations found in common industrial effluents, the order of selectivity in multi-solute systems can be affected by interaction of complex factors such as the cationic radii (e.g., $\mathrm{Pb}^{2+}=1.19 \AA$

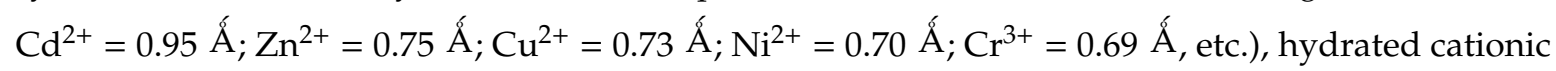

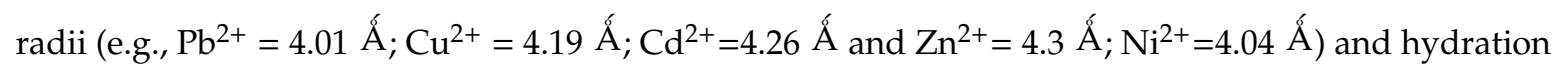
energy (e.g., $\mathrm{E}_{\mathrm{h}}\left(\mathrm{Pb}^{2+}\right)=-1481 \mathrm{~kJ} \mathrm{~mol}^{-1}<\mathrm{E}_{\mathrm{h}}\left(\mathrm{Cd}^{+2}\right)=-1807 \mathrm{~kJ} \mathrm{~mol}^{-1}<\mathrm{E}_{\mathrm{h}}\left(\mathrm{Ni}^{2+}\right)=-2106 \mathrm{~kJ} \mathrm{~mol}^{-1}$ $\left.<\mathrm{E}_{\mathrm{h}}\left(\mathrm{Zn}^{2+}\right)=-2046 \mathrm{~kJ} \mathrm{~mol}^{-1}<\mathrm{E}_{\mathrm{h}}\left(\mathrm{Cu}^{2+}\right)=-2119 \mathrm{kJmol}^{-1}<\mathrm{E}_{\mathrm{h}}\left(\mathrm{Cr}^{3+}\right)=-4560 \mathrm{~kJ} \mathrm{~mol}^{-1}\right)$ [107-112]. The ionic radius of metal ions is inversely related to the charge density and electrostatic attraction, which, in turn, limits the interaction of the metal ions with adsorption sites $[108,109,113]$. Furthermore, metal ions with higher Pauling electronegativity (e.g., $\mathrm{Pb}^{2+}(\chi=2.33)>\mathrm{Ni}^{2+}(\chi=1.91)>\mathrm{Cd}^{2+}(\chi=1.69)$ $\left.>\mathrm{Cr}^{3+}(\chi=1.66)>\mathrm{Zn}^{2+}(\chi=1.65)>\mathrm{Cu}^{2+}(\chi=1.90)\right)$ and lower hydration energy adsorb more readily onto the surface of adsorbents $[108,109,113]$.

A number of studies have attempted to elaborate the mechanism of competitive adsorption in multi-solute systems $[19,70,77,89,100,107-109,111]$. For example, Gao et al. [86] proposed the adsorption of $\mathrm{Cd}^{2+}=\mathrm{Ni}^{2+}=\mathrm{Pb}^{2+}=2 \mathrm{mg} \mathrm{L}^{-1} ; \mathrm{Cu}^{2+}=0.1 \mathrm{mg} \mathrm{L}^{-1}$ by iron-rich slag to follow the following selectivity sequence: $\mathrm{Pb}^{2+}>\mathrm{Cu}^{2+}>\mathrm{Ni}^{2+}>\mathrm{Cd}$. In a similar study, Dimitrova [70] observed the adsorption behaviour of a multi-solute system consisting of $\mathrm{Cu}^{2+}, \mathrm{Ni}^{2+}$ and $\mathrm{Zn}^{2+}$ on blast furnace slags to follow the selectivity sequence $\mathrm{Cu}^{2+}>\mathrm{Zn}^{2+}>\mathrm{Ni}^{2+}$. Xue et al. [77] also proposed the selectivity sequence of both single-solute and multi-solute adsorption systems of $\mathrm{Cu}^{2+}=\mathrm{Cd}^{2+}=\mathrm{Pb}^{2+}=\mathrm{Zn}^{2+}$ $=0.21 \mathrm{mmol} \mathrm{L}^{-1}$ at $\mathrm{pH}_{50}$ and $13.6 \mathrm{~g} \mathrm{~L}^{-1}$ BOF slag to follow $\mathrm{Zn}^{2+}>\mathrm{Cu}^{2+}>\mathrm{Pb}^{2+}>\mathrm{Cd}^{2+}$ in single-solute systems, and $\mathrm{Pb}^{2+}>\mathrm{Cu}^{2+}>\mathrm{Zn}^{2+}>\mathrm{Cd}^{2+}$ in multi-solute systems. The higher preference for adsorption for $\mathrm{Pb}^{2+}$ ions, for example, in multi-solute systems can be attributed to lower cationic radii (4.01 $⿱$ Á), lower hydration energy $\left(-1807 \mathrm{~kJ} \mathrm{~mol}^{-1}\right)$ and higher Pauling electronegativity $(\chi=2.33)$, which resulted in stronger electrostatic interaction with the active functional groups present in the slag $[77,108,109,113]$. Similarly, Liu et al. [89] conducted a multi-solute adsorption study involving $\mathrm{Cr}^{3+}, \mathrm{Cu}^{2+}, \mathrm{Pb}^{2+}$ and $\mathrm{Zn}^{2+}$ ions at $25 \mathrm{mg} \mathrm{L}^{-1}$ each, with $120 \mathrm{~g} \mathrm{~L}^{-1}$ of steelmaking slag, and proposed the adsorption sequence to follow $\mathrm{Cr}^{3+}>\mathrm{Zn}^{2+}>\mathrm{Cu}^{2+}>\mathrm{Pb}^{2+}$. The preferential adsorption behaviour of $\mathrm{Cr}^{3+}$ was attributed to the higher electrostatic attraction as a result of the higher charge density of the $\mathrm{Cr}^{3+}$ ions. In other words, the smaller the cationic radii and the greater the valence, the more closely and strongly the ion was adsorbed onto adsorbent surfaces [107-113]. The findings by Liu et al. [89], however, were inconclusive regarding the adsorption selective behaviour of the other ions $\left(\mathrm{Zn}^{2+}, \mathrm{Cu}^{2+}\right.$ and $\left.\mathrm{Pb}^{2+}\right)$ in solution with $\mathrm{Cr}^{3+}$, which in essence, presents both challenges and opportunities for future studies to elaborate further the mechanistic behaviour of such multi-solute industrial systems.

The decrease in solute adsorption from multi-solute systems relative to their respective single systems can be attributed to the effects of competitive adsorption as the metal ions compete for active sites present on the surface of the adsorbent $[19,70,77,86,89,113-116]$. Xue et al. [77] proposed that metal ions that form hydrolysis products (e.g., $\mathrm{Cu}^{2+}, \mathrm{Pb}^{2+}$ and $\mathrm{Zn}^{2+}$ ) are more readily adsorbed to variable-charge surfaces at higher $\mathrm{pH}$ values. It is thus assumed that an increase in amounts of more strongly bonded ions reduces the number of adsorption sites available for further adsorption of 
other cations from multi-solute systems. According to Neris et al. [113], the presence of other ions in multi-solute industrial effluents and wastewaters can affect the ability to remove certain metal ions present in aqueous solutions, either through synergistic or antagonistic competitive effects.

\section{Opportunities to Enhance the Adsorption Performance of Slags}

The performance of slags as adsorbents largely depends on their physical properties (e.g., internal pore volume, porosity and internal surface area), chemical composition and phase chemical properties. These properties are, in turn, affected by the degree of crystallisation achieved during the solidification process. Thus, to date, several studies have demonstrated the correlation between the adsorption capacity and the degree of crystallisation of the slags. In fact, the presence of crystalline phases such as gehlenite $\left(\mathrm{Ca}_{2} \mathrm{Al}_{2} \mathrm{SiO}_{7}\right)$ and akermanite $\left(\mathrm{Ca}_{2} \mathrm{MgSiO}_{7}\right)$ has been suggested to significantly increase the adsorption capacity of granulated blast furnace slags $[15,19,57]$. Nonetheless, the chemical and geometric heterogeneities arising from variable chemical and phase chemical compositions, and cooling and the crystallisation behaviours, often result in inconsistencies of the adsorption properties of slags $[59,77]$. This is particularly the case for pore structure and specific surface area, as such properties tend to be strongly dependent on the cooling and crystallization behaviour.

The adsorption properties of slags reported in Table 5 are significantly lower than those reported for commercial adsorbents (Table 1). Nevertheless, ironmaking and steelmaking slags are still comparatively attractive for use as low-cost adsorbents since they are inexpensive byproducts produced in large volumes $[3,4,25,117]$. In addition, ironmaking and steelmaking slags have high mechanical strength properties and, as such, the adsorbents derived from these materials are most likely to have desirable properties such as high resistance to abrasion and attrition when in use [117]. Thus, in order to overcome the obvious performance challenges and increase the utilisation potential of slags as adsorbents, several techniques have been proposed to modify the core functional properties of slags in order to improve their adsorption capacities.

To date, several studies have reported on the benefits of modification and/or activation treatment to increase the specific surface area and density of adsorption sites on the surfaces of the adsorbent particles $[42,57,59-66]$. Other studies have also proposed the synthesis of functionalised adsorbents such as geopolymers [74,118-123], permeable reactive barriers or slag filters [124-132], zeolites and zeolite precursors [133-135] and layered double-hydroxide-based adsorbents [133-138]. This section discusses in detail the opportunities to improve the adsorption capacity of slag-based adsorbents. In particular, it discusses the common modification and activation techniques and their impact on the adsorption performance of the slags. It also provides a brief overview of properties of permeable reactive filters, slag-based zeolites and layered double hydroxides. It concludes by highlighting the application of these novel slag-based adsorbents in the treatment of industrial effluents and wastewater.

\subsection{Activated Slags and Their Performance as Adsorbents}

It has been proposed that the performance of activated slags is comparable to that of activated carbon $[3,15,42,59,70]$. Basically, slags can be activated via three main routes, namely thermal, mechanochemical and alkali activation. The following subsections discuss in detail the various activation methods and the resulting adsorption capacities of the activated slags.

\subsubsection{Thermal Activation}

Thermal activation involves purposeful heat treatment, with and without additives, to increase the amount of crystalline phases in solidified slags. To date, extensive studies have highlighted the benefits of activation of slags for use in the adsorption of cations and anions from industrial effluents and wastewaters [42,57,59-66,139,140]. In particular, Yang et al. [139] investigated the effect of nitrate removal by thermally activated steelmaking slags mixed with $\mathrm{Al}(\mathrm{OH})_{3}$. The performance of slags modified at $800^{\circ} \mathrm{C}$ was 1.9 times higher than that of unmodified slags. The superior performance was attributed to a 3.34-fold increase in specific surface area and a 2-fold increase in the total pore volume 
of thermally modified slags [139]. Islam and Patel [60] observed an increase in porosity from $9.74 \%$ to $17.89 \%$, and in specific surface area from $5.62 \mathrm{~m}^{2} \mathrm{~g}^{-1}$ to $40.89 \mathrm{~m}^{2} \mathrm{~g}^{-1}$, in BOF slags thermally activated at $1000{ }^{\circ} \mathrm{C}$ for $24 \mathrm{~h}$. The fluoride adoption capacity of the thermally activated slags was also significantly higher than that of un-activated slags [60]. In earlier studies, Dimitrova et al. [15] also investigated the adsorption $\mathrm{Cu}^{2+}$ ions on $\mathrm{g}$-BFS heat-treated between $400{ }^{\circ} \mathrm{C}$ and $1000^{\circ} \mathrm{C}$. Their findings indicated that the thermal activation of the largely amorphous g-BFS at temperatures greater than $600^{\circ} \mathrm{C}$ facilitated the formation of crystalline phases such as $\mathrm{Ca}_{2} \mathrm{Al}_{2} \mathrm{SiO}_{7}, \mathrm{Ca}_{2} \mathrm{MgSi}_{2} \mathrm{O}_{7}$ and $\mathrm{CaAl}_{2} \mathrm{Si}_{2} \mathrm{O}_{8}$, which in turn, resulted in a 2-4-fold increase in the adsorption capacity for $\mathrm{Cu}^{2+}$ ions.

\subsubsection{Mechanochemical Activation}

Mechanochemical activation uses mechanical energy to promote the rate of reaction in physicochemical processes. It involves the compound effects of particle fracture and other bulk and surface physicochemical changes [140-144]. The adsorption capacity of slags can thus be enhanced by the finer particles, physicochemical activation, and the higher specific surface area arising from mechanochemically induced dislocations and other defects $[59,65,140,142,144]$. Of particular interest to this review are studies by Andini et al. [144] and Li et al. [65]. Andini et al. [144] investigated the mechanochemical activation of blast furnace slags using different milling conditions in a planetary mill (charge ratios, $C_{R}=50$, and $C_{R}=100$; rotational speeds, $v=300 \mathrm{rpm}$ and $600 \mathrm{rpm}$; and time, $t=15 \mathrm{~min}$ and $120 \mathrm{~min}$ ). The specific surface area, total specific porosity and specific mesoporosity of milled materials significantly increased from $7 \mathrm{~m}^{2} \mathrm{~g}^{-1}, 0.0239 \mathrm{~cm}^{3} \mathrm{~g}^{-1}$ and $0.0149 \mathrm{~cm}^{3} \mathrm{~g}^{-1}$ in untreated samples to $15.5 \mathrm{~m}^{2} \mathrm{~g}^{-1}, 0.5963 \mathrm{~cm}^{3} \mathrm{~g}^{-1}$ and $0.1885 \mathrm{~cm}^{3} \mathrm{~g}^{-1}$, respectively, after milling at $C_{R}=50 ; v=300 \mathrm{rpm}$ and $t=15 \mathrm{~min}$. However, further increasing the severity of milling conditions to $C_{R}=100 ; v=600 \mathrm{rpm}$ and $t=120 \mathrm{~min}$ marginally increased the specific surface area, total specific porosity and specific mesoporosity to $8 \mathrm{~m}^{2} \mathrm{~g}^{-1}, 0.0642 \mathrm{~cm}^{3} \mathrm{~g}^{-1}$, and $0.0298 \mathrm{~cm}^{3} \mathrm{~g}^{-1}$, respectively. The observed behaviour at more severe mechanochemical activation conditions was attributed to increased agglomeration of particles. In a recent study, Li et al. [65] investigated the adsorption of phosphorus on steelmaking slag modified by high-energy planetary milling. The specific surface area and the total pore volume of the modified slags increased from $2.96 \mathrm{~m}^{2} \mathrm{~g}^{-1}$ and $0.0046 \mathrm{~cm}^{3} \mathrm{~g}^{-1}$ to $4.85 \mathrm{~m}^{2} \mathrm{~g}^{-1}$ and $0.016 \mathrm{~cm}^{3} \mathrm{~g}^{-1}$, respectively. In addition to the faster adsorption equilibrium, the observed P-adsorption by modified slag was 2.6 times higher than that of un-modified slags. These findings clearly demonstrated the beneficial effects of mechanochemical activation on the adsorption performance of slags $[65,144]$.

\subsubsection{Alkali Activation and Geopolymerisation of Slags}

Alkali-activated slags, also known as geopolymers, are synthesised from the reaction of a solid aluminosilicate precursor under alkaline conditions to produce a product consisting of hydrous alkali-aluminosilicate and/or alkali-alkali-earth-aluminosilicate phases [74,117-123,145]. Geopolymers are amorphous or partly crystalline materials composed of $\left[\mathrm{SiO}_{4}\right]^{4-}$ and $\left[\mathrm{AlO}_{4}\right]^{5-}$ 3D-tetrahedral structures linked randomly by covalently shared oxygen atoms $[74,118,121,123,145]$. The negative charge of the $\left[\mathrm{AlO}_{5}\right]^{5-}$ tetrahedron is balanced by exchangeable alkali and alkali-earth cations such as $\mathrm{Na}^{+}, \mathrm{K}^{+}, \mathrm{Ba}^{2+}$ and $\mathrm{Ca}^{2+}$ ions. Thus, the high cation-exchange capacity makes them ideal candidates for the adsorption of heavy metal ions from solution, since the extra framework cations can be replaced by dissolved cations through ion-exchange reactions. Furthermore, the high porosity and surface area also significantly increase the adsorption capacity for heavy metal ions $[117,121]$.

As discussed in Section 2, ironmaking and steelmaking slags belong to the $\mathrm{CaO}-\mathrm{SiO}_{2}-\mathrm{MgO}-\mathrm{Al}_{2} \mathrm{O}_{3}$ system. Thus, these slags typically contain significant amounts of silica, aluminosilicates and calcium-aluminosilicate phases, which makes them ideal precursors for the synthesis of low-cost, slag-based geopolymer adsorbents. To date, extensive studies have focused on evaluating the performance of geopolymerised slags as novel functionalized adsorbents and photocatalysts in the treatment of industrial effluents and wastewaters [74,117,119-123,146,147]. 
Zhang et al. [118] synthesised a Ni-Ca cementitious-materials-based catalyst from steelmaking slag via a two-step reaction involving polymerisation and ion exchange. The Ni-Ca cementitious material achieved over $94 \%$ photocatalytic degradation of methylene blue dye under ultraviolet irradiation. In a similar study, Zhang et al. [146] proposed a three step process of polymerisation, ion exchange, and impregnation to synthesise a novel catalyst from alkali-activated granulated blast-furnace-slag-based cementitious material (ASCM) doped with $\mathrm{Fe}_{2} \mathrm{O}_{3}$. The cementitious product was then applied to photocatalytically degrade Congo red dye. The photocatalytic reaction was observed to follow second-order reaction kinetics. The high degradation efficiency was attributed to the strong interaction between the ASCM and the active $\mathrm{Fe}_{2} \mathrm{O}_{3}$ species [118].

Runtti et al. [74] conducted a comparative evaluation of adsorption of capacities of $\mathrm{SO}_{4}{ }^{2-}$ ions from mine wastewater using BFS, metakaolin (MK), geopolymerised blast furnace slag (BFS-GP) and metakaolin geopolymers (MK-GP). The BFS and metakaolin geopolymers were also modified by incorporating barium, in the form of $\mathrm{BaCl}_{2}$, into the geopolymer matrix. High specific surface areas were achieved in BFS-GP $\left(64.5 \mathrm{~m}^{2} \mathrm{~g}^{-1}\right)$ and Ba-modified BFS-GP $\left(63.1 \mathrm{~m}^{2} \mathrm{~g}^{-1}\right)$, compared to unmodified BFS $\left(2.79 \mathrm{~m}^{2} \mathrm{~g}^{-1}\right)$, MK $\left(11.5 \mathrm{~m}^{2} \mathrm{~g}^{-1}\right)$ and MK-GP $\left(22.4 \mathrm{~m}^{2} \mathrm{~g}^{-1}\right)$. Furthermore, the Ba-modified geopolymerised materials exhibited higher $\mathrm{SO}_{4}{ }^{2-}$ ion-removal capacity compared to similar but ungeopolymerised materials. Since geopolymers naturally have a low affinity for the sorption of anions (e.g., $\mathrm{SO}_{4}{ }^{2-}$ ), the Ba-modification of geopolymerised materials represented a technical opportunity to achieve low residual concentrations of $\mathrm{SO}_{4}{ }^{2-}\left(<2 \mathrm{mg} \mathrm{L}^{-1}\right)$ in mine effluents.

In a similar study, Luukkonen et al. [119] investigated the simultaneous removal of $\mathrm{Ni}$ (II), As (III) and $\mathrm{Sb}$ (III) from spiked mine effluents using metakaolin and blast furnace slag geopolymers. The specific surface areas of unmodified BFS, geopolymerised BFS (BFS-GP), unmodified metakaolin (MK) and metakaolin geopolymers (MK-GP) were in the order of $2.79 \mathrm{~m}^{2} \mathrm{~g}^{-1}, 64.5 \mathrm{~m}^{2} \mathrm{~g}^{-1}, 11.5 \mathrm{~m}^{2} \mathrm{~g}^{-1}$, and $22.4 \mathrm{~m}^{2} \mathrm{~g}^{-1}$, respectively. The micropore volume of BFS-GP increased from $0.001 \mathrm{~cm}^{3} \mathrm{~g}^{-1}$ to $0.025 \mathrm{~cm}^{3} \mathrm{~g}^{-1}$, while the macro- and mesopore volumes also increased from $0.008 \mathrm{~cm}^{3} \mathrm{~g}^{-1}$ to $0.070 \mathrm{~cm}^{3} \mathrm{~g}^{-1}$, respectively, as a result of geopolymerisation. Despite the low sorption capacities obtained for $\mathrm{Ni}^{2+}, \mathrm{As}^{3+}$ and $\mathrm{Sb}^{3+}$ ions (3.74 $\mathrm{mg} \mathrm{g}^{-1}, 0.52 \mathrm{mg} \mathrm{g}^{-1}$ and $0.34 \mathrm{mg} \mathrm{g}^{-1}$, respectively), possibly due to the non-synergistic competitive adsorption behaviour among the adsorbates, the results indicated BFS-GP to be the most effective sorbent compared to BFS, MK and MK-GP.

In a more recent study, Sarkar et al. [147] synthesised a geopolymer from calcium-oxide-rich BOF slag, using a $\mathrm{NaOH}$ and $\mathrm{Na}_{2} \mathrm{SiO}_{3}$ mixture $(1: 1 \mathrm{w} / \mathrm{w})$, to form a product consisting of a tetrahedral porous matrix consisting of $\mathrm{Ca}_{2} \mathrm{SiO}_{4}$ and $\mathrm{Ca}_{3} \mathrm{SiO}_{5}$. The specific surface area and total pore volume in geopolymerised slag increased from $4.859 \mathrm{~m}^{2} \mathrm{~g}^{-1}$ and $0.018 \mathrm{~cm}^{3} \mathrm{~g}^{-1}$ to $30.84 \mathrm{~m}^{2} \mathrm{~g}^{-1}$ and $0.091 \mathrm{~cm}^{3} \mathrm{~g}^{-1}$,

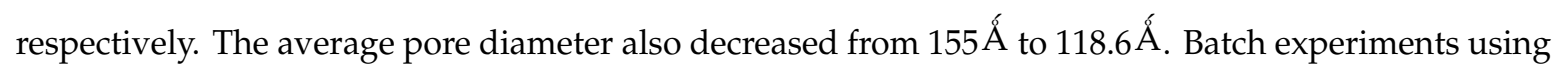
geopolymerised BOF slag achieved maximum adsorption uptake of $\mathrm{Ni}^{2+}$ of $85.29 \mathrm{mg} \mathrm{g}^{-1}$ at $318 \mathrm{~K}$ from a solution containing initial $175 \mathrm{mg} \mathrm{L}^{-1} \mathrm{Ni}^{2+}$. The adsorption rate followed a pseudo-second-order model, further indicating that the process was dominated by chemisorption.

\subsection{Slag-Based Permeable Reactive Barrier Materials}

To date, extensive studies have focused on developing efficient and long-lasting filter media for constructed wetlands. Constructed wetlands (CWs) are subsurface constructions situated across the path of contaminated effluent flow, and constitute low-cost artificial treatment systems commonly used for in situ passive treatment of municipal and industrial wastewaters [126]. Their performance is thus strongly related to the physicochemical and hydrological properties of the filter materials $[148,149]$. Due to the low cost and high abundance of ferrous slags, the use of slag-based reactive permeable materials (herein interchangeably referred to as slag filters) in CWs has attracted global attention in recent years. To date, slag-based permeable reactive media have extensively been investigated as a promising technology in the economical remediation of municipal and agricultural wastewaters, acid mine drainage, landfill leachates and other contaminated process waters [71,124-132,150-153]. By their nature, ironmaking and steelmaking slags contain significant amount of lime (e.g., 30-50 wt. \% CaO 
for $\mathrm{BOF}$ slags) occurring either as free $\mathrm{CaO}$ or as $\mathrm{CaO}$ bound to various silicate, aluminate and ferrite phases such as $\mathrm{Ca}_{14} \mathrm{Mg}_{2}\left(\mathrm{SiO}_{4}\right)_{8}, \mathrm{Ca}_{2} \mathrm{Al}_{2} \mathrm{SiO}_{7}$ and $\mathrm{Ca}_{2} \mathrm{Fe}_{2} \mathrm{O}_{4}$. Thus, slag filters made from the basic calcium-rich slags are of particular interest, as the chemical and hydration reactions result in high effluent $\mathrm{pH}$, adsorption capacity and chemical precipitation [125-132,152].

Bowden et al. [152] investigated the removal of phosphorus using BOF slag (normalised composition 39.9 wt. \% $\mathrm{CaO}, 10.2$ wt. $\% \mathrm{SiO}_{2}, 3.2$ wt. \% $\mathrm{Al}_{2} \mathrm{O}_{3}, 5.1$ wt. \% $\mathrm{MgO}, 34.6 \mathrm{FeO}, 4.2 \% \mathrm{MnO}$, 2.3 wt. $\% \mathrm{P}_{2} \mathrm{O}_{5}$, and 0.5 wt. $\% \mathrm{TiO}_{2}$ ). Long-term continuous flow column tests achieved effective phosphorus $\left(\mathrm{C}_{0}=1-50 \mathrm{mg} \mathrm{L}^{-1}\right)$ removal of up to $62 \%$ after 406 days. Phase characterisation of loaded slags indicated the formation of increasingly less soluble octacalcium phosphate $\left(\mathrm{Ca}_{8} \mathrm{H}_{2}\left(\mathrm{PO}_{4}\right)_{6} \cdot 5 \mathrm{H}_{2} \mathrm{O}\right)$, brushite $\left(\mathrm{CaHPO}_{4} \cdot 2 \mathrm{H}_{2} \mathrm{O}\right)$ and hydroxyapatite $\left(\left(\mathrm{Ca}_{5}\left(\mathrm{PO}_{4}\right) \mathrm{OH}\right)\right)$ phases on the surfaces of the slags. Pratt et al. [125] also proposed the removal of phosphate ions from P-effluent solutions to occur via adsorption onto the amorphous Fe-oxyhydroxides dominating the porous matrix and surface of the slag, followed by precipitation of stable Ca-Fe-P-O precipitates on the slag surfaces.

Claveau-Mallet et al. [132] investigated the long-term column treatment of multi-component mining leachate containing phosphate, fluoride, $\mathrm{Mn}^{2+}$ and $\mathrm{Zn}^{2+}$ ions using EAF-based reactive slag filters. The slag filter system containing approx. $7 \%$ readily soluble $\mathrm{Ca}_{14} \mathrm{Mg}_{2}\left(\mathrm{SiO}_{4}\right)_{8}$ phases achieved a removal efficiency of $99.9 \% \mathrm{P}, 85.3 \% \mathrm{~F}, 98 \% \mathrm{Mn}^{2+}$ and $99.3 \% \mathrm{Zn}^{2+}$ after 179 days of operation. Claveau-Mallet et al. [132] proposed that the removal of phosphates, fluorides and metal ions $\left(\mathrm{Mn}^{2+}\right.$ and $\left.\mathrm{Zn}^{2+}\right)$ in Ca-rich slag filters was $\mathrm{pH}$-dependent and occurred mainly via the formation of hydroxyapatite $\left(\mathrm{Ca}_{5}\left(\mathrm{PO}_{4}\right) \mathrm{OH}\right)$ and fluoroapatite $\left(\mathrm{Ca}_{5}\left(\mathrm{PO}_{4}\right)_{3} \mathrm{~F}\right.$ phases on the surfaces of slags [132].

Barca et al. [128] investigated the removal of phosphorus $\left(C_{0}=10 \mathrm{mg} \mathrm{L}^{-1}\right)$ from a wastewater treatment plant using EAF (normalized composition: 35.2 wt. \% FeO, 27.4 wt. \% $\mathrm{CaO}, 15.3 \mathrm{wt} . \% \mathrm{SiO}_{2}$, 10.1 wt. $\% \mathrm{Al}_{2} \mathrm{O}_{3}, 9.4$ wt. $\% \mathrm{MnO}, 2.0$ wt. $\% \mathrm{MgO}$, and 0.6 wt. $\% \mathrm{P}_{2} \mathrm{O}_{5}$ ) and $\mathrm{BOF}$ (normalized composition: 29.2 wt. \% FeO, 44.7 wt. \% $\mathrm{CaO}, 12.3$ wt. \% $\mathrm{SiO}_{2}, 1.4$ wt. \% $\mathrm{Al}_{2} \mathrm{O}_{3}, 3.5$ wt. \% $\mathrm{MnO}$, 7.0 wt. $\% \mathrm{MgO}$, and 1.8 wt. $\% \mathrm{P}_{2} \mathrm{O}_{5}$ ) slags. P-removal performance after 52 week longitudinal tests improved with increasing $\mathrm{CaO}$ content in the slags, as well as with decreasing particle sizes of the slag particles. In particular, smaller-sized EAF slags (5-16 $\mathrm{mm})$ and BOF slags $(6-12 \mathrm{~mm})$ achieved $98 \%$ (0.91 $\mathrm{g} \mathrm{P} \mathrm{kg}^{-1}$ EAF slag) and $>99 \%$ (1.05 $\mathrm{g} \mathrm{P} \mathrm{kg}^{-1}$ BOF slag), respectively, compared to $88 \%$ (0.81 $\mathrm{g} \mathrm{P} \mathrm{kg}^{-1}$ EAF slag) and $95 \%$ (1.01 $\mathrm{g} \mathrm{P} \mathrm{kg}^{-1}$ BOF slag) for larger-sized EAF (20-40 mm) and BOF (20-50 mm) slags, respectively. Similarly, Barca et al. [128,129] conducted longitudinal 2 year field experiments to investigate P-removal performance using EAF slag (unnormalised composition: 43.7 wt. $\% \mathrm{Fe}_{2} \mathrm{O}_{3}, 26.0$ wt. \% $\mathrm{CaO}$, and 14.4 wt. $\% \mathrm{SiO}_{2} ; 20-40 \mathrm{~mm}$ ) and $\mathrm{BOF}$ (unnormalised composition: 54.6 wt. $\% \mathrm{CaO}, 27.0$ wt. $\% \mathrm{Fe}_{2} \mathrm{O}_{3}$, and 13.3 wt. \% $\mathrm{SiO}_{2} ; 20-40 \mathrm{~mm}$ ) slags in $\mathrm{CWs}$. Over the 2 year period, EAF slag-based filters removed $37 \%$ of the total inlet $\mathrm{P}$, compared to $62 \%$ removal in BOF slag-based filters. The P-removal efficiencies increased with increasing $\mathrm{CaO}$ content, as well as with increasing temperature and hydraulic retention ratio for both slags. Barca et al. [128,129] proposed the mechanism of $\mathrm{P}$ removal to be controlled by the dissolution of Ca-bearing phases from slags, followed by the precipitation of Ca-phosphates and their accumulation onto the filters.

Sasaki et al. [151] investigated the immobilisation of arsenate and other ions in groundwater impacted by acid mine drainage using a permeable reactive barrier column containing granulated blast furnace slag. At $\mathrm{pH}=2$, the $\mathrm{As}^{5+}$ decreased from $15 \mathrm{mg} \mathrm{L}^{-1}$ to $0.4 \mathrm{mg} \mathrm{L}^{-1}$. The authors proposed the removal mechanism to involve the formation of hydrated calcium arsenate phases from the co-precipitation with iron oxyhydroxides on the surfaces of the adsorbent [151]. Similarly, Ahn et al. [124] evaluated the comparative performance of BF and BOF slags on the removal of $\mathrm{As}^{5+}$ and $\mathrm{As}^{3+}$ from tailings leachate (variable $\mathrm{pH} ; \mathrm{As}^{5+}=\mathrm{As}^{3+}=25 \mathrm{mg} \mathrm{L}^{-1}$ ). The BOF slag proved to be a better sorbent due to the higher $\mathrm{CaO}$ content, which favoured the formation of Ca-As compounds. The importance of $\mathrm{CaO}$ in the immobilisation of arsenate, via the formation of 
low-solubility calcium-arsenates, has also been emphasised in other studies [154-157], and is proposed to occur according to the following reactions (Equations (16)-(18)).

$$
\begin{gathered}
\mathrm{HAsO}_{4}^{2-}+\mathrm{Ca}^{2+}+n \mathrm{H}_{2} \mathrm{O} \rightarrow \mathrm{CaHAsO}_{4} \cdot n \mathrm{H}_{2} \mathrm{O} \\
2 \mathrm{AsO}_{4}^{3-}+3 \mathrm{Ca}^{2+}+n \mathrm{H}_{2} \mathrm{O} \rightarrow \mathrm{Ca}_{3}\left(\mathrm{AsO}_{0}\right)_{2} \cdot n \mathrm{H}_{2} \mathrm{O} \\
2 \mathrm{HAsO}_{4}^{3-}+4 \mathrm{Ca}^{2+}+6 \mathrm{H}_{2} \mathrm{O} \rightarrow \mathrm{Ca}_{4}(\mathrm{OH})_{2}\left(\mathrm{AsO}_{4}\right)+\cdot 4 \mathrm{H}_{2} \mathrm{O}+6 \mathrm{H}^{+}
\end{gathered}
$$

The studies highlighted so far indicate the high potency of ironmaking and steelmaking slags as permeable reactive media for remediating contaminated wastewaters and effluents. However, the long-term environmental impact of slag-based permeable reactive media requires further research. For example, the concomitant leachability of the dissolved and/or entrained metal species within the slag matrix, particularly for steelmaking slags, under different solution $\mathrm{pH}$ conditions requires further research. Thus, the global acceptance of in situ slag-based permeable reactive filters is predicated on developing an in-depth understanding of their long-term toxicity characteristic leaching behaviour $[24,158,159]$. The potential environmental challenges of steelmaking-slag-based adsorbents are further discussed in Section 6.

\subsection{Synthesis of Zeolites from Slags}

Unlike their geopolymer counterparts, which are amorphous or partly crystalline, zeolites are microporous, crystalline aluminium-silicates, with group I or II as counterions. The structure of a zeolite is made up of a framework of $\left[\mathrm{SiO}_{4}\right]^{4-}$ and $\left[\mathrm{AlO}_{4}\right]^{5-}$ tetrahedrally linked to each other at the corners by sharing their oxygens [13,160-162]. Figure 1 shows an idealised structure of a zeolite framework of tetrahedral $\left[\mathrm{SiO}_{4}\right]^{4-}$, with a $\mathrm{Si} / \mathrm{Al}$ substitution $\left(\left[\mathrm{AlO}_{4}\right]^{5-}\right.$ yielding a negative charge, and consequently a cation-exchange capacity $[13,160]$.

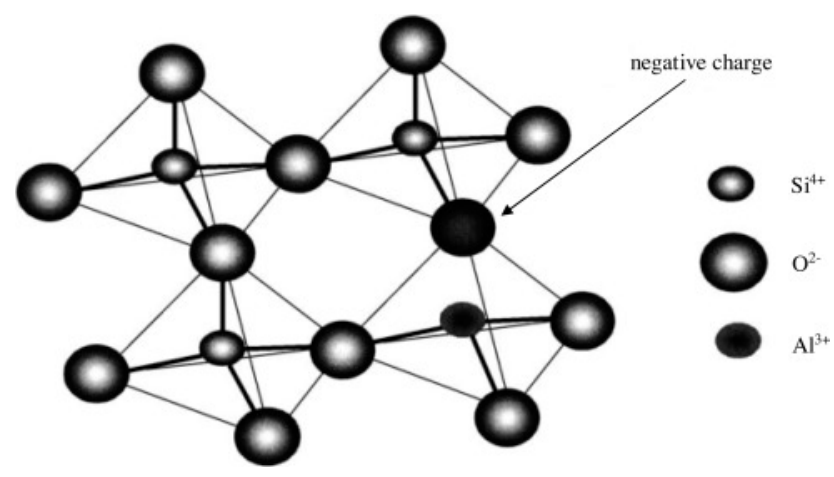

Figure 1. Idealised structure of a zeolite framework [160].

Zeolites can be natural or synthetic in nature. Natural zeolites, formed through natural geological processes, typically possess a honeycomb-like structure consisting of openings or pores of the order of a few atoms in width ( 2-10Á) [161]. In contrast, synthetic zeolites are synthesized by hydrothermal chemical processes using calcium-rich aluminosilicate materials as feedstocks [161]. Conventional hydrothermal processes involve reaction of the zeolite precursors with alkaline media such as $\mathrm{NaOH}$, $\mathrm{Na}_{2} \mathrm{SiO}_{3}, \mathrm{Na}_{2} \mathrm{CO}_{3}$ and $\mathrm{KOH}$. The type and quality of the zeolite formed is thus a function of the hydrothermal temperatures, pressures, concentration of reagent solutions, $\mathrm{pH}$, process of activation and ageing period. Synthetic zeolites also tend to possess more uniform lattice structures and uniformly sized pores when compared to their natural counterparts [13,160-162].

Zeolites are clinoptilolitic in nature, and exhibit a strong affinity for the sorption of heavy metal ions from solutions [116,161-167]. Furthermore, the adsorption properties of zeolites depend on their high cation-exchange capabilities, and channel or pore diameter and volume [13,122,160-163]. The 3D 
structure of zeolites possesses large channels containing negatively charged sites, with the negative charge being balanced by cations such as $\mathrm{Na}^{+}, \mathrm{K}^{+}, \mathrm{Ca}^{2+}$ and $\mathrm{Mg}^{2+}[13,160-162]$. The exchangeable cations occupy channels within the structure, and can easily be replaced by heavy metal cations [163]. Furthermore, the channels are microscopically small, thereby facilitating cation exchange during the adsorption process [161,162].

In essence, zeolites can be classified as low-silica, intermediate-silica, or high-silica zeolites, and the $\mathrm{Si} / \mathrm{Al}$ molar ratio of the zeolite precursors thus determines the type and properties of the zeolite produced [161,162]. Thus, the high silica, aluminosilicate and calcium-aluminosilicate content of ironmaking and steelmaking slags makes them ideal precursors for the synthesis of zeolites and their variants. To date, several studies have explored the synthesis of zeolites using ironmaking and steelmaking slags as precursors [133-135]. In particular, Sugano et al. [133] synthesised type-A zeolite from the hydrothermal treatment of synthetic BFSs under different temperature conditions $\left(328<\mathrm{T}<358 \mathrm{~K} ; 1 \mathrm{M} \mathrm{NaOH}\right.$ solution; and solution to slag ratio of $\left.15 \mathrm{~mL} \mathrm{~g}^{-1}\right)$. The direct hydrothermal treatment of $\mathrm{BFS}$ mixed with $\mathrm{SiO}_{2}$ and $\mathrm{Al}_{2} \mathrm{O}_{3}(\mathrm{Si} / \mathrm{Al}=1$ and $\mathrm{CaO}+\mathrm{MgO}=15$ mass \%) produced a zeolite product containing 50 mass \% Na-P1 $\left.\left(\mathrm{Na}_{6}\left(\mathrm{Si}_{10} \mathrm{Al}_{6} \mathrm{O}_{32}\right) \cdot 12 \mathrm{H}_{2} \mathrm{O}\right)\right)$ and 50 mass \% of combined tobermorite $\left(\mathrm{Ca}_{5} \mathrm{Si}_{6} \mathrm{O}_{16}(\mathrm{OH})\right)$ and hydrogarnet $\left(3 \mathrm{CaO} \cdot \mathrm{Al}_{2} \mathrm{O}_{3} \cdot(3-\mathrm{x}) \mathrm{SiO}_{2} \cdot 2 x \mathrm{H}_{2} \mathrm{O}\right.$ (where $\left.0 \leq \mathrm{x} \leq 3\right)$. Further optimizing the zeolite precursors by adding suitable amounts of $\mathrm{SiO}_{2}$ and replacing the $\mathrm{Al}_{2} \mathrm{O}_{3}$ with $\mathrm{NaAlO}_{2}$ produced 75 mass \% of type-A zeolite $\left.\left(\mathrm{Na}_{12}\left[\mathrm{AlO}_{2}\right)_{12}\left(\mathrm{SiO}_{2}\right)_{12}\right] \cdot 27 \mathrm{H}_{2} \mathrm{O}\right)$ and 25 mass \% of combined tobermorite and hydrogarnet. The ratio of type- $\mathrm{A}$ zeolite was increased to 82 mass $\%$ by using remelted $\mathrm{BFS}$ and $\mathrm{SiO}_{2}$ and $\mathrm{Al}_{2} \mathrm{O}_{3}$ mixture ( $\mathrm{Si} / \mathrm{Al}=1$ and $\mathrm{CaO}+\mathrm{MgO}=15$ mass \%) [133].

$\mathrm{Li}$ et al. [135] synthesised a mixture of $\mathrm{NaA}$ (Linde Type A: $6 \mathrm{CaO} \cdot 6 \mathrm{Al}_{2} \mathrm{O}_{3} \cdot 12 \mathrm{SiO}_{2}$ ) and sodalite $\left(4 \mathrm{Na}_{2} \mathrm{O} \cdot 2 \mathrm{Al}_{2} \mathrm{O}_{3} \cdot 6 \mathrm{SiO}_{2}\right)$ zeolites from the hydrothermal treatment of titanium-bearing EAF slag. A NaA zeolite with good crystallinity and cubic morphology was obtained at $140{ }^{\circ} \mathrm{C}$ for $3 \mathrm{~h}$ at $\mathrm{n}\left(\mathrm{SiO}_{2}\right) / \mathrm{n}\left(\mathrm{Al}_{2} \mathrm{O}_{3}\right)=2: 1$ and $\mathrm{n}\left(\mathrm{H}_{2} \mathrm{O}\right) / \mathrm{n}\left(\mathrm{Na}_{2} \mathrm{O}\right)=100: 1$. The transformation from metastable NaA zeolite to a high-framework-density sodalite zeolite was favoured by decreasing the $n\left(\mathrm{H}_{2} \mathrm{O}\right) / \mathrm{n}\left(\mathrm{Na}_{2} \mathrm{O}\right)$ to $40: 1$ while increasing the hydrothermal temperature and time to $160{ }^{\circ} \mathrm{C}$ and $12 \mathrm{~h}$, respectively. However, the adsorption capacity for $\mathrm{Cu}^{2+}$ ions by NaA synthesised at $120^{\circ} \mathrm{C}$ was significantly higher $\left(1.346 \mathrm{mmol} \mathrm{g}^{-1}\right)$ than that of sodalite synthesised at $140{ }^{\circ} \mathrm{C}\left(0.722 \mathrm{mmol} \mathrm{g}{ }^{-1}\right)$ and $160{ }^{\circ} \mathrm{C}$ $\left(0.673 \mathrm{mmol} \mathrm{g}^{-1}\right)$. In an earlier study, Kuwahara et al. [134] also synthesized FAU-type zeolites (Type X, Type Y) using a two-step hydrothermal treatment of Ti-bearing steelmaking slag. The FAU-type zeolite was applied as a support for the $\mathrm{TiO}_{2}$ photocatalyst for the degradation of organic pollutants. The photocatalytic activity increased with increasing Si/Al ratio. Due to the abundance of major constituent elements such $\mathrm{Ti}, \mathrm{Si}$ and $\mathrm{Al}$ in slags, these studies clearly highlight novel approaches to the utilisation of otherwise problematic Ti-bearing steelmaking slags [134,135].

\subsection{Synthesis of Layered Double Hydroxides from Slags}

Layered double hydroxides (LDHs) belong to a class of nanostructured and lamellar-structured anionic clay minerals consisting of positively charged metal hydroxide sheets, exchangeable counter ions and water molecules in the hydrotalcite-like interlayers [136,168-174]. The general formula of an LDH can be expressed as $\left[\mathrm{M}^{2+}{ }_{1-\mathrm{x}} \mathrm{M}^{3+}{ }_{\mathrm{x}}(\mathrm{OH})_{2}\right]^{\mathrm{x}+}\left(\mathrm{A}^{\mathrm{n}-}\right)_{\mathrm{x} / \mathrm{n}} \cdot \mathrm{mH}_{2} \mathrm{O}$, where $\mathrm{M}^{2+}$ and $\mathrm{M}^{3+}$ represent divalent and trivalent metal cations such as $\mathrm{Mg}^{2+}$ and $\mathrm{Al}^{3+}$, respectively; $\mathrm{A}^{\mathrm{n}-}$ represents an intercalated anion for charge compensation; $x$ is the charge density (c.a. $0.25<x<0.33$ ); and $\mathrm{m}$ is the number of interlayer water molecules $[136,168,170,172]$. Due to the ubiquitous structural and physicochemical properties such as interlayer anion-exchange ability, easy accommodation of cations in the hydroxide layer and strong basicity, LDHs have attracted widespread attention as novel adsorbents in the treatment of industrial effluents and wastewaters [136,168-177].

To date, extensive studies have investigated the performance of LDHs in the removal of anions and cations from problematic anthropogenic wastes and effluents. Bagherifam et al. [169] investigated the removal of As (III) and As (VI) co-existing with $\mathrm{SO}_{4}{ }^{3-}$ and $\mathrm{CO}_{3}{ }^{2-}$ in soils using $\mathrm{Zn}-\mathrm{Al}_{-}-\mathrm{SO}_{4} \mathrm{LDHs}$. The authors observed maximum adsorption capacities of $34.24 \mathrm{mg} \mathrm{g}^{-1}$ and $47.39 \mathrm{mg} \mathrm{g}^{-1}$, respectively. 
Zhang et al. [174] also observed an incremental adsorption capacity of $\mathrm{Cr}(\mathrm{VI})$ by $\mathrm{Fe}_{3} \mathrm{O}_{4} / \mathrm{C} / \mathrm{Mg} / \mathrm{Al} \mathrm{LDH}$ with increase in solution $\mathrm{pH}$ ( $\mathrm{pH}$ range 2-6). A maximum adsorption capacity of $143.3 \mathrm{mg} \mathrm{g}^{-1}$ was observed at $\mathrm{pH}=6$. However, the equilibrium adsorption capacity decreased with further increase in $\mathrm{pH}$ from 6 to 12. Ling et al. [175] observed high adsorption efficiencies for methyl red and $\mathrm{Cr}(\mathrm{VI})$ using $\mathrm{Co} / \mathrm{Fe} \mathrm{LDHs}(\mathrm{Co} / \mathrm{Fe}=2: 1,3: 1$, and 4:1), and proposed the adsorption mechanism to involve external surface adsorption and interlayer anion exchange. Similarly, Lu et al. [177] investigated the adsorption behaviour of methyl orange and $\mathrm{Cr}(\mathrm{VI})$ ions using Ni/Fe LDHs ( $\mathrm{Ni} / \mathrm{Fe}=4: 1,3: 1,7: 3$, and 1:1). Maximum adsorption capacities of $205.76 \mathrm{mg} \mathrm{g}^{-1}$ methyl orange and $26.78 \mathrm{mg} \mathrm{g}^{-1} \mathrm{Cr}(\mathrm{VI})$ were observed for $\mathrm{Ni} / \mathrm{Fe}=4: 1$. In a separate study, Gong et al. [176] investigated the competitive adsorption behaviour of heavy metal ions from multi-solute effluents using anisotropic $\mathrm{Mg}_{2} \mathrm{Al}-\mathrm{LDH}$ nanocrystals. The removal efficiencies for $\mathrm{Cu}^{2+}, \mathrm{Cd}^{2+}$ and $\mathrm{Pb}^{2+}$ were observed to be $99.7 \%, 89.3 \%$ and $55.4 \%$, respectively. Gong et al. [176] proposed the adsorption behaviour to involve isomorphic substitution coupled with adsorption bonding with the surface hydroxyl groups and surface precipitation. The order of selectivity $\left(\mathrm{Cu}^{2+}>\right.$ $\left.\mathrm{Cd}^{2+}>\mathrm{Pb}^{2+}\right)$ was attributed to the closer ionic radii of $\mathrm{Cu}^{2+}(0.073 \mathrm{~nm})$ and $\mathrm{Cd}^{2+}(0.093 \mathrm{~nm})$ to that of $\mathrm{Mg}^{2+}$ in the LDH for isomorphic substitution, compared to that of $\mathrm{Pb}^{2+}(0.119 \mathrm{~nm})$ [176].

Given the novelty of LDHs as adsorbents, the straightforward synthesis of novel LDHs from ironmaking and steelmaking slags has begun to gain traction in recent years. In particular, the synthesis of LDHs from ironmaking and steelmaking slags provides interesting opportunities for enhancing the valorisation of these waste materials [136-138,168]. Kuwahara et al. [136] proposed a straightforward synthesis of a single-phase, Ca-based LDH material from blast furnace slags using a two-step process of hydrochloric acid leaching and precipitation. The synthesis process produced two streams, a residue containing $92 \mathrm{wt} . \% \mathrm{SiO}_{2}$ and a leachate containing $\mathrm{Ca}$ and other dissolved metals. The leachate was then precipitated with $\mathrm{NaOH}$ to produce a Ca-Al-based hydrocalumite compound (with $\mathrm{Ca}: \mathrm{Al}: \mathrm{Cl}=2: 1: 1$ ). The phosphate adsorption capacity of the Ca-Al-based hydrocalumite increased significantly, from $1.5 \mathrm{mg} \mathrm{g}^{-1}$ in raw slag to $40 \mathrm{mg} \mathrm{g}^{-1}$, and was three times greater than that of the conventional Mg-Al-based hydrotalcites. Furthermore, single-phase Type-A and Type- $X$ zeolites with exceptional water adsorption capacities ( $247 \mathrm{mg} \mathrm{g}^{-1}$ and $333 \mathrm{mg} \mathrm{g}^{-1}$, respectively) were synthesised from the conventional hydrothermal treatment (conc. $\mathrm{NaOH}, 100^{\circ} \mathrm{C}, 6 \mathrm{~h}$ ) of the hydrated silica residue [136].

Kuwahara et al. [137] also synthesised a calcium-silicate hydrate (CSH) via a two-step dissolution-co-precipitation of $\mathrm{BFS}$ using $\mathrm{HCl}$ and $\mathrm{NaOH}$. The optimised conditions $(\mathrm{pH}=11$ and $\mathrm{T}=100^{\circ} \mathrm{C}$ ) produced a calcium-silicate hydrate product with stoichiometry $\mathrm{Ca}: \mathrm{Si}=1: 1$, incorporating other metal cations derived from slags $\left(\mathrm{Al}^{3+}, \mathrm{Mg}^{2+}, \mathrm{Fe}^{3+}, \mathrm{Ti}^{3+}\right.$ and $\left.\mathrm{Mn}^{2+}\right)$ into its structure. The observed high adsorption to $\mathrm{Cu}^{2+}$, phosphate ions and model proteins was attributed to the large specific surface area $\left(219 \mathrm{~m}^{2} \mathrm{~g}^{-1}\right)$, pore volume $\left(0.78 \mathrm{~cm}^{3} \mathrm{~g}^{-1}\right)$ and cation-exchange properties associated with hydrated $\mathrm{Ca}^{2+}$ ions abundant in the network structure. In a similar study, Shao et al. synthesised hierarchically structured CSH nanocomposites from the direct alkaline activation of steelmaking slags. The CSH-based materials exhibited fast kinetics and high adsorption capacity for $\mathrm{Cu}^{2+}\left(Q_{\max }=244 \mathrm{mg} \mathrm{L}^{-1}\right)$, $\mathrm{Zn}^{2+}\left(Q_{\max }=273 \mathrm{mg} \mathrm{L}^{-1}\right)$ and $\mathrm{Pb}^{2+}\left(508 \mathrm{mg} \mathrm{L}^{-1}\right)$ ions. Shao et al. proposed the excellent adsorption performance to result from the release of $\mathrm{Ca}^{2+}$ and $\mathrm{OH}^{-}$from the $\mathrm{CSH}$ nanocomposites. Furthermore, the calcined spent $\mathrm{CSH}$ product exhibited high reusability potential as a photocatalyst in the degradation of methylene blue dye [137].

The findings from these and several other studies clearly demonstrate the potency of LDH-based adsorbents in the removal of anions and cations from both single- and multi-solute solutions [136,168-176]. In particular, the findings highlight the potential to utilise ironmaking and steelmaking slags as low-cost, high-value feedstocks in the synthesis of novel LDH-based adsorbents for treating industrial effluents and wastewaters. Nonetheless, this research is still in its infancy, and further work is still required to optimize and scale up the synthesis to industrial scale before these LDHs can gain global prominence. 


\section{Environmental Challenges of Steelmaking-Slag-Based Adsorbents}

Unlike g-BFS, which have widely been accepted as having low toxic potency, the adoption of steelmaking slags in external markets is still at its infancy [22,23]. As highlighted in Tables 3 and 4, the heterogeneity of chemical and phase properties of steelmaking slags complicate their adoption as low-cost adsorbents. Furthermore, steelmaking slags are also associated with significant amounts of dissolved and/or entrained alloying elements such as $\mathrm{Cr}, \mathrm{Ni}, \mathrm{Mn}, \mathrm{Mo}$ and V [22,23,178]. Thus, the application of steelmaking slags as low-cost adsorbents is constrained by the potential concomitant dissolution and speciation of these toxic metal elements under different environmental conditions. The environmental impact of steelmaking slags is further exacerbated by the high toxicity and potential mobility of these elements, particularly chromium, in environmental ecosystems [22-24,159,179-185].

Chromium is an indispensable alloying element used in large quantities in the production of various grades of steels (approx. 10.5-30 wt. \% Cr in stainless steels) $[178,186,187]$. However, chromium is one of the most problematic heavy metal species typically found in steelmaking slags. This is due to its significantly higher environmental potency compared to other alloying elements listed above $[22,23,178]$. In fact, chromium, in the form of the hexavalent state $(\mathrm{Cr}(\mathrm{VI}))$, is classified as one of the most potent mutagenic, carcinogenic and teratogenic agents known to man [22-24,180-182]. Given the high anthropogenic potency of chromium, the environmental behaviour of chromium-containing steelmaking-slag-based adsorbents requires further debate. Therefore, this section focuses in detail on the potential of concomitant dissolution of chromium from steelmaking-slag-based adsorbents. Techniques used to stabilise the chromium in stable phases in slags in order to reduce its potential leachability are also discussed.

\subsection{Toxicity and Environmental Challenges of Chromium Bearing Slags}

Chromium is an indispensable alloying element in the production of stainless steels. In fact, the production of ferrochromium alloys and stainless steel products constitutes one of the major anthropogenic sources of chromium [22,23,181,186,187]. As shown in Table 4, the chromium in steelmaking slags can exist in different forms and oxidation states. Basically, chromium can exist as oxides dissolved in slags (e.g., $\left.(\mathrm{Mg}, \mathrm{Mn})(\mathrm{Cr}, \mathrm{Al}, \mathrm{Fe})_{2} \mathrm{O}_{4} ; \mathrm{FeCr}_{2} \mathrm{O}_{4} ; \mathrm{CaCrO}_{4}\right)$ or as entrained zero-valent $\mathrm{Cr}$ and/or $\mathrm{Cr}$ in solid solution with other metals (e.g., Fe-Cr-Ni solid solution). Essentially, most of the chromium dissolved in slag exists in the +3 oxidation state. In the trivalent oxidation state, chromium is stable and has limited mobility in the environment. However, the transformation from the stable trivalent to the unstable hexavalent state is thermodynamically feasible under different oxidative environmental conditions. In the hexavalent state, chromium is highly toxic, soluble in water and highly mobile in the environment $[22-24,54,183,185,186]$. The non-biodegradability of $\mathrm{Cr}(\mathrm{VI})$ species further presents long-term ecological risks, as they tend to persist in the environment [182]. Thus, the typical environmental challenges of Cr-bearing slag-based adsorbents typically arise from the potential oxidation and redox reactions involving the unstable $\mathrm{Cr}$-bearing phases to form $\mathrm{Cr}(\mathrm{VI})$ species under different environmental conditions [22,23,54,180-182,184].

Several studies highlighted in the preceding sections investigated the adsorption performance of steelmaking slags under different environmental conditions. However, few studies, if any, have attempted to evaluate the potential of concomitant dissolution of $\mathrm{Cr}$-bearing phases from these steelmaking-slag-based adsorbents. The presence of readily soluble $\mathrm{Cr}$-bearing phases (e.g., $\mathrm{CaCrO}_{4}$, $\mathrm{CaCr}_{2} \mathrm{O}_{4}, \mathrm{Ca}_{4} \mathrm{Al}_{6} \mathrm{CrO}_{16}$ and zero-valent $\mathrm{Cr}$ and/or $\mathrm{Cr}$ in solid solution with $\mathrm{Fe}$ and $\mathrm{Ni}$ ) in steelmaking slags increases the probability of concomitant dissolution of the chromium phases [54,188-190]. Furthermore, as highlighted earlier, $\mathrm{Cr}(\mathrm{VI})$ is generated via the oxidation of anthropogenic $\mathrm{Cr}(\mathrm{III})$. The chemistry of chromium in any given environmental compartment thus depends on conditions such as $\mathrm{pH}$, concentration, hydrolysis, redox, complexation and/or adsorption conditions [179-184]. Likewise, species commonly occurring in steelmaking slags, industrial effluents and in the natural environment, such as ferrous iron, manganese oxides and organic matter, can result in the rapid oxidation of $\mathrm{Cr}(\mathrm{III})$ to $\mathrm{Cr}(\mathrm{VI})[179,180,182,183]$. Nonetheless, to date, the effects of the various 
environmental conditions on the leachability and oxidation of $\mathrm{Cr}$ species in steelmaking-slag-based adsorbents are not clear and/or have largely been ignored by most researchers. Thus, it is important for future research to investigate the short and long-term toxicity characteristic leaching behaviours of, and the release of $\mathrm{Cr}$ species from, steelmaking-slag-based adsorbents under different environmental conditions $[24,158,159]$.

\subsection{Stabilisation of Chromium in Slags}

The chromium in steelmaking slags exists in readily soluble oxidation states. Thus, if not stabilised, the chromium in these phases can elute into the environment $[22,23,180,181]$. To date, extensive studies have demonstrated effective techniques to stabilise the dissolved and/or entrained $\mathrm{Cr}$ phases in slags during and after solidification. Technically, the environmental performance of Cr-bearing slags can be improved by controlled post-furnace flux additions and/or variations in the cooling paths [52,54,188-198].

Tanskanen and Makkonen [193] investigated the chemical and phase chemical compositions of air-cooled high-carbon ferrochrome $(\mathrm{HCFeCr})$ slags containing 8 mass $\% \mathrm{Cr}$. The authors observed the presence of low-Cr phases such as glass, forsterite, pyroxene and $\mathrm{Mg}-\mathrm{Al}$ spinel phases, as well as $\mathrm{Cr}$-rich Mg-Al-Cr spinel phases (Figure 2). The authors proposed the $\mathrm{Mg}(\mathrm{Al}, \mathrm{Cr})_{2} \mathrm{O}_{4}$ and $\mathrm{Mg}(\mathrm{Al}, \mathrm{Cr})_{2} \mathrm{O}_{4}$ spinel phases to be the main chromium-binding phases in the slag [193].

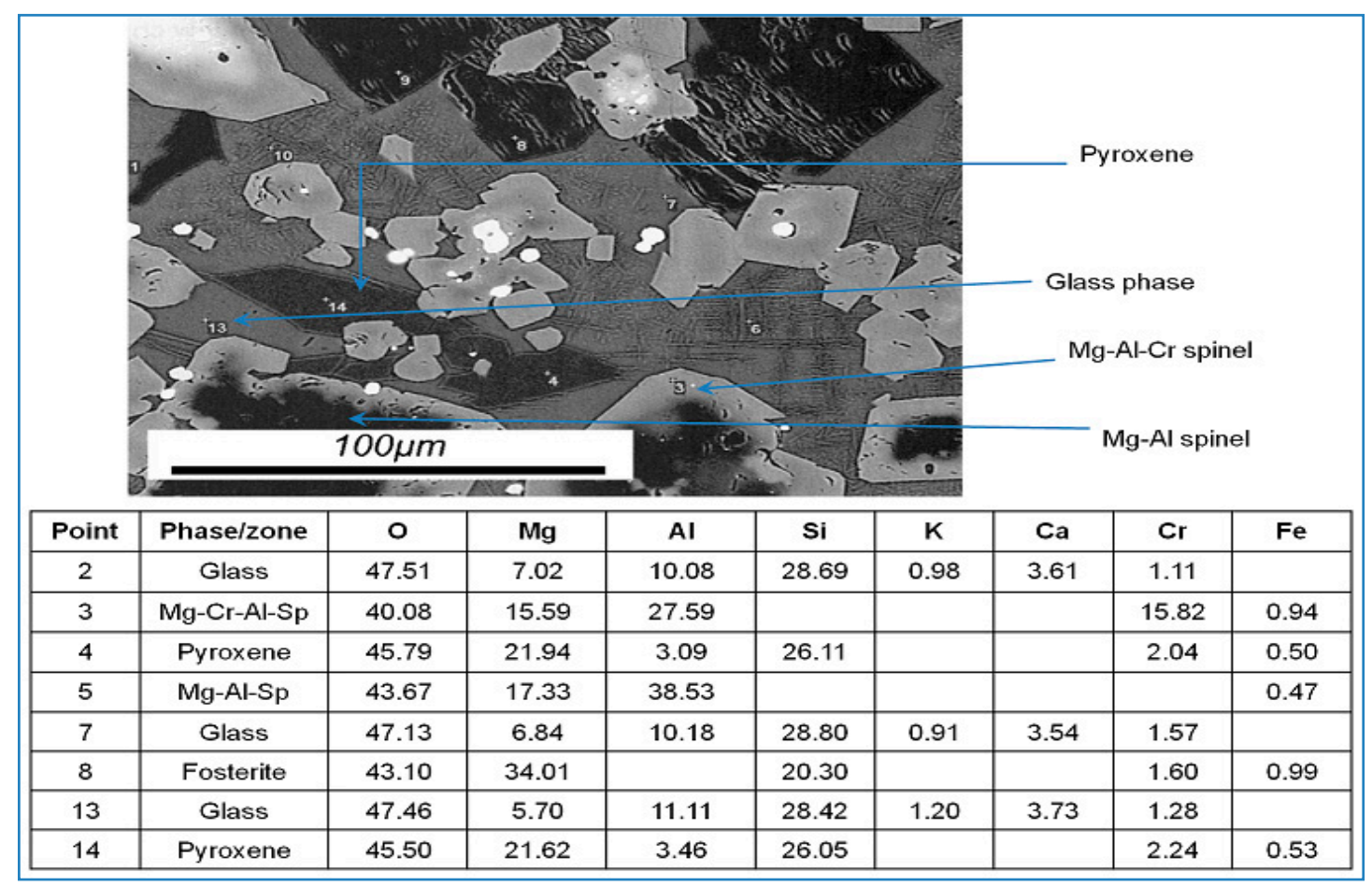

Figure 2. Phase chemical composition of air-cooled HCFeCr slags [23,193].

Kühn and Mudersbach [192] proposed that the addition of $\mathrm{MgO}, \mathrm{Al}_{2} \mathrm{O}_{3}$ and $\mathrm{FeO}$ prior to the crystallisation of molten stainless steelmaking slags stabilised the chromium in stable spinel phases such as $(\mathrm{Mg}, \mathrm{Fe})(\mathrm{Al}, \mathrm{Cr})_{2} \mathrm{O}_{4}, \mathrm{FeCr}_{2} \mathrm{O}_{4}$ and $\mathrm{MgCr}_{2} \mathrm{O}_{4}$, thereby reducing its leachability. $\mathrm{Kühn}$ and Mudersbach [192] also proposed the binding efficiency of the spinel phases to be a function of the spinel factor (Factor sp) (Equation (19)).

$$
\text { Factor } \left.s p=f\left\{0.2 \mathrm{MgO}+1.0 \mathrm{Al}_{2} \mathrm{O}_{3}+n \mathrm{FeO}-0.5 \mathrm{Cr}_{2} \mathrm{O}_{3}\right\} ; 1 \leq n \leq 4\right)
$$


A Factor $s p$ less than or equal to 5 denotes high $\mathrm{Cr}$ leaching, while between 5 and 25 denotes less than $0.05 \mathrm{mg} \mathrm{L}^{-1} \mathrm{Cr}$ leaching. Lastly, a factor sp greater than 25 denotes little or no chromium leaching. Figure 3 shows the correlation between the spinel factor and the measured chromium leaching levels [54,192].

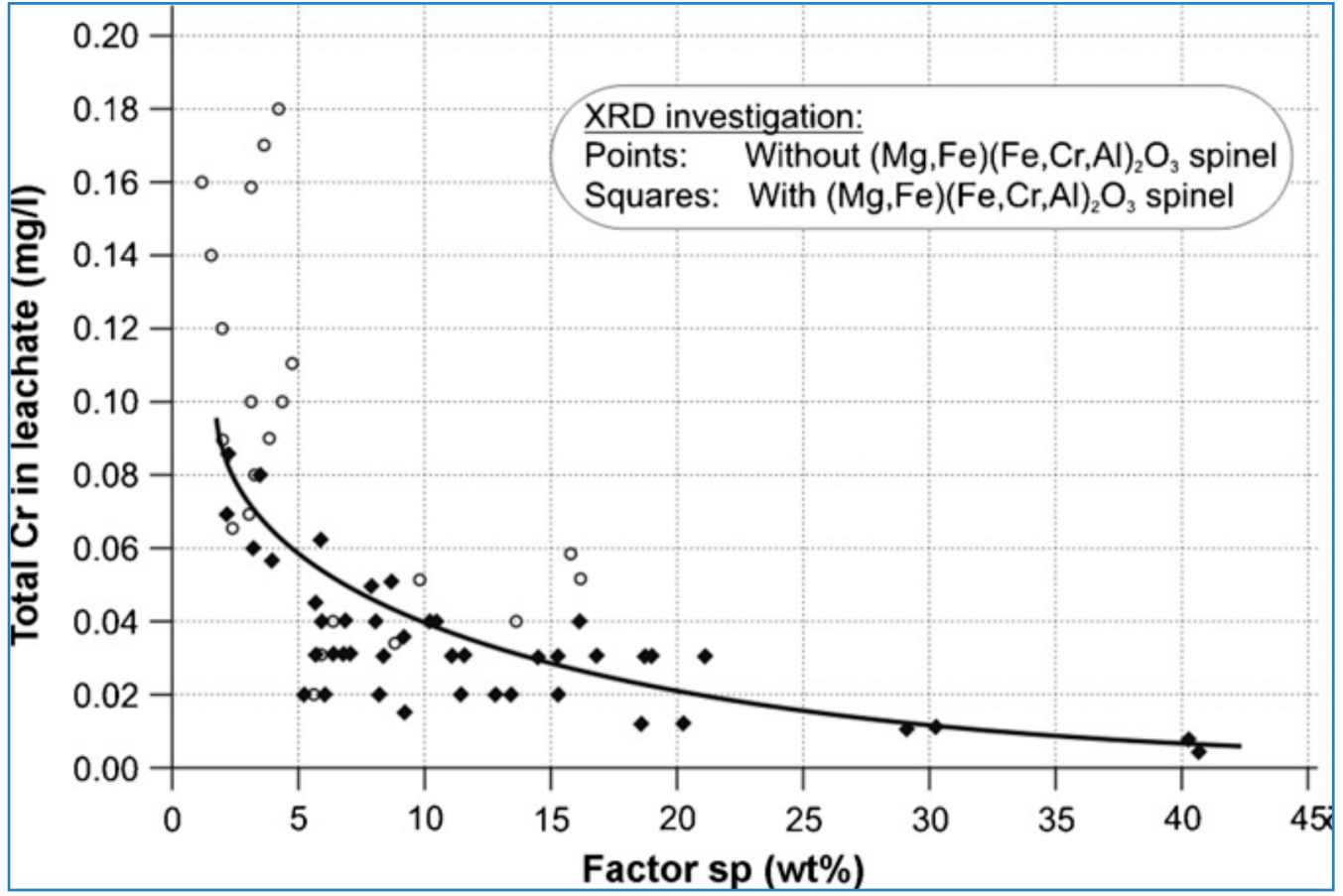

Figure 3. Chromium leaching as a function of spinel factor (Factor $s p$ ) [54,192].

Albertsson [194] also observed that the addition of $\mathrm{Al}_{2} \mathrm{O}_{3}$ to molten stainless steelmaking slags increased the chromium partition ratio to the stable $\mathrm{MgAl}_{2} \mathrm{O}_{4}-\mathrm{MgCr}_{2} \mathrm{O}_{4}$ spinel phases. In an earlier study, Cabrera-Real et al. [189] investigated the effect of basicity $\left(\mathrm{CaO} / \mathrm{SiO}_{2}\right)$ ratio and $\mathrm{MgO}$ content on the crystallisation behaviour of $\mathrm{CaO}-\mathrm{SiO}_{2}-\mathrm{Cr}_{2} \mathrm{O}_{3}-\mathrm{CaF}_{2}-\mathrm{MgO}$ slags. The predominance of a stable spinel phase, $\mathrm{MgCr}_{2} \mathrm{O}_{4}$, and the minor presence of soluble $\mathrm{CaCr}_{2} \mathrm{O}_{4}$ phases was observed at $\mathrm{CaO} / \mathrm{SiO}_{2}=1$. However, the amount of $\mathrm{CaCr}_{2} \mathrm{O}_{4}$ and $\mathrm{Ca}_{5}\left(\mathrm{CrO}_{4}\right)_{4} \mathrm{~F}$ increased at $\mathrm{CaO} / \mathrm{SiO}_{2} \geq 2$. Similarly, the effect of $\mathrm{Al}_{2} \mathrm{O}_{3}$ and $\mathrm{MgO}$ content and $\mathrm{CaO} / \mathrm{SiO}_{2}$ ratio on the crystallisation of $\mathrm{CaO}-\mathrm{SiO}_{2}-\mathrm{Cr}_{2} \mathrm{O}_{3}-\mathrm{MgO}$ slag system was also demonstrated by Garcia-Ramos et al. [188]. The authors observed the presence of soluble $\mathrm{CaCr}_{2} \mathrm{O}_{4}, \mathrm{CaCrO}_{4}$ and $\mathrm{Ca}_{4} \mathrm{Al}_{6} \mathrm{CrO}_{16}$ phases in slags solidified without $\mathrm{MgO}$ or $\mathrm{Al}_{2} \mathrm{O}_{3}$ addition, and proposed that the $\mathrm{CaO} / \mathrm{SiO}_{2}$ ratio must be maintained at $\mathrm{CaO} / \mathrm{SiO}_{2}<2$ in order to mitigate the formation of the soluble phases [188]. Garcia-Ramos et al. [188] also proposed the order of solubility of $\mathrm{Cr}$-bearing species in acidic environments to follow the sequence $\mathrm{MgCr}_{2} \mathrm{O}_{4}>\mathrm{CaCr}_{2} \mathrm{O}_{4}>\mathrm{Ca}_{4} \mathrm{Al}_{6} \mathrm{CrO}_{16}$ $>\mathrm{CaCrO}_{4}$.

From the studies highlighted in this subsection, mitigating the solubility of chromium from slags is strongly dependent on its ability to partition to spinel-forming compounds. From Figures 2 and 3 , it is clear that the concomitant dissolution of chromium under different environmental conditions encountered in adsorption processes can be mitigated by purposeful processing in the molten state and controlling the crystallisation behaviour of the slags. In other words, it is possible to control the phases and speciation of $\mathrm{Cr}$ in steelmaking-slag-based adsorbents by integrating post-furnace fluxing and controlling their crystallisation and solidification behaviour [54,192,194].

\subsection{Integrating Metal Recovery from Steelmaking Slags}

The recovery of alloying elements from slags not only increases the intrinsic monetary value of the slags, but also reduces their environmental impact during reuse as low-cost adsorbents. To date, 
several physical, pyrometallurgical, hydrometallurgical and/or combinations of different processes have been proposed to recover the valuable metal alloys from slags while producing an environmentally benign barren slag product (Figure 4) [21-23,53,55]. Physical beneficiation methods such as gravity and magnetic separation have traditionally been applied to recover entrained alloying elements such as $\mathrm{Cr}$ and $\mathrm{Ni}$ in alloys while producing a barren slag product suitable for use as an adsorbent. However, physical beneficiation methods may not suitable for metal species dissolved in silicate phases $[53,56]$. Pyrometallurgical processing under carbothermic or metallothermic conditions can be used to completely reduce the metal oxides dissolved in slag into metallic forms and separate them from slag based on differential settling and density behaviours. Lastly, in hydrometallurgical processing, the dissolved and/or entrained metals in slags are separated using differences in constituent solubilities and/or electrochemical properties while in aqueous solution $[21,53,55,199]$.

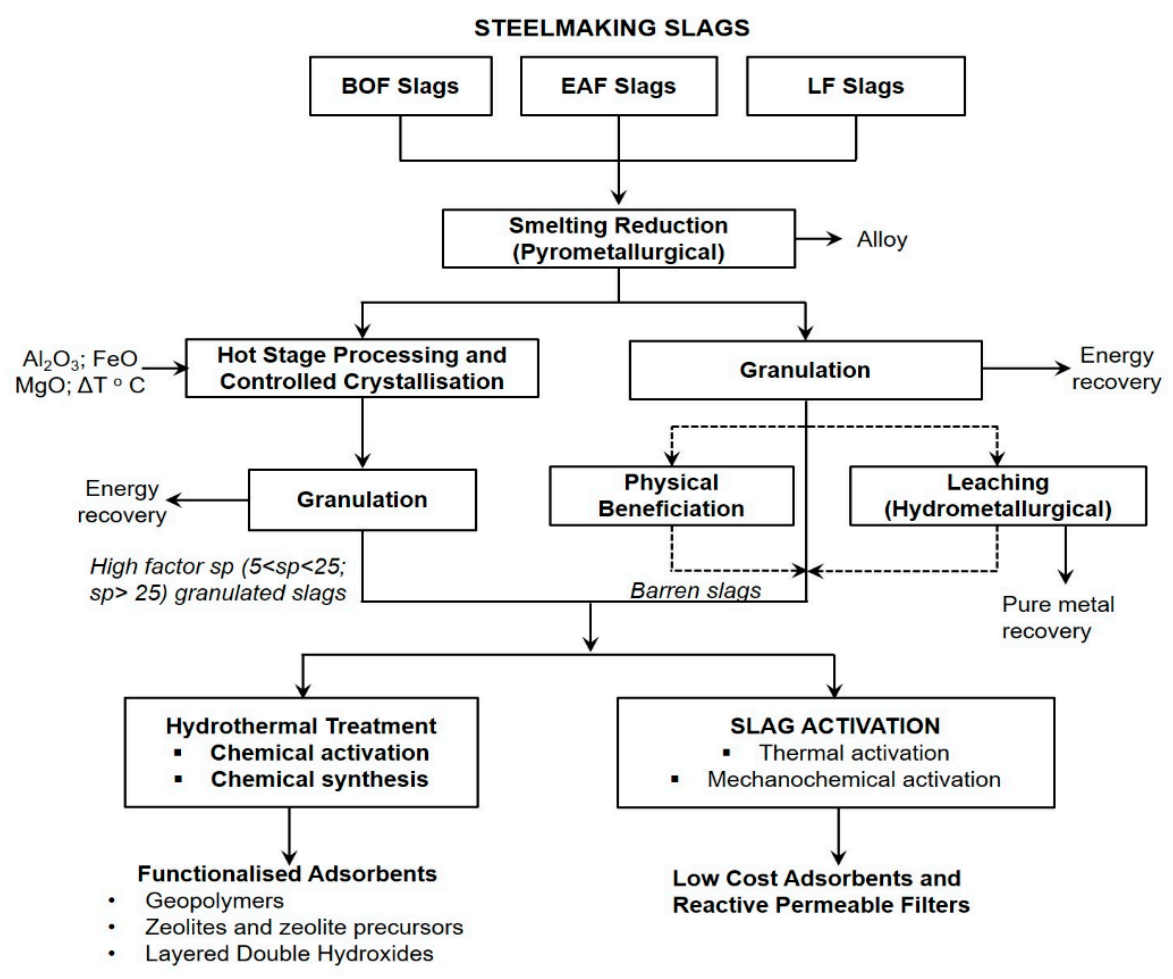

Figure 4. Simplified process flowsheet integrating metal recovery and the production of environmentally benign barren slag products from steelmaking slags.

\section{Mitigating the Environmental Challenges of Spent Slag Adsorbents}

The environmental performance of ironmaking- and steelmaking-slag-based adsorbents discussed so far is predicated on their short- and long-term toxicity characteristic leaching properties (TLCPs). In fact, one of the major challenges of slag-based adsorbents is the accumulation of solid wastes loaded with high concentration of toxic cations and anions [158,200]. Unlike organic pollutants which tend to degrade over time, the toxicity of heavy metals commonly associated with steelmaking slags is exacerbated by their persistence in the ecosystem [201]. The uncontrolled disposal of spent slag adsorbents thus presents long-term environmental challenges as a result of secondary pollution caused by the release of toxic pollutants into the environment [202]. Essentially, two major approaches can be adopted to mitigate the environmental impact of spent slag adsorbents, namely: (i) regeneration, recycling and reuse, and (ii) immobilisation treatment.

The ability to be regenerated, recycled and reused is one of the key characteristic properties of granular adsorbents. The regenerability, recyclability and reusability of spent slag adsorbents not only improves the economics of the process, but also reduces the environmental footprint of the 
adsorption systems. In addition to recycling and reuse, immobilisation treatment is also an effective approach to address the environmental impact of spent-slag-based adsorbents and other inorganic solid wastes. Over the years, the immobilisation of hazardous wastes using cementitious materials and thermal treatment methods has, in fact, been proven to be effective in reducing the mobility of toxic ions in the environment [201,203-211]. This section briefly discusses the opportunities and challenges in the regeneration of spent-slag-based and other inorganic adsorbents. It further discusses the immobilisation of hazardous wastes, specifically spent slag adsorbents and similar inorganic solid wastes, using cementitious materials and thermal treatment.

\subsection{Regeneration, Recycling and Reuse of Spent-Slag-Based Adsorbents}

Adsorbents lose their characteristic adsorptive capacity after multiple adsorption cycles, and must thus be regenerated and recycled. The recyclability of the spent adsorbents is controlled by their ability to be regenerated without losing adsorptive capacity and/or without further generating waste streams $[8,61,212-214]$. In essence, regeneration refers to the process of reactivating spent adsorbents for reuse in an adsorption cycle. Shahadat et al. [213] also defined regeneration as the rapid recycling or recovery of spent adsorbents using technically and economically feasible methods. Thus, the selection of a regeneration method not only depends on the type of adsorbents, adsorbate-adsorbent interactions, scale and performance of regeneration processes, but also on the appropriateness and costs of the technologies involved $[8,200]$.

Among the various technical options available, thermal and chemical methods, or combinations thereof, are the most commonly used regeneration methods used for a variety of granular adsorbents [8,61,200,213-215]. Thermal regeneration involves heating an adsorbent to a particular temperature to break the bonds between the adsorbate and adsorbent without degrading the adsorbent $[61,213]$. Chemical regeneration involves the decomposition of particular species using specific solvents and/or chemical species in solutions [213]. These methods are relatively cheap and simple, and can be easily be applied at industrial scales. However, these thermochemical methods, in their various forms, have inherent challenges such as loss of structure within the inorganic adsorbents, leading to reduced absorption capacity, loss of adsorbent during each treatment cycle and challenges in recovering adsorbates after regeneration [8,61,200,212-215].

\subsubsection{Regeneration of Spent-Slag-Based Adsorbents}

To date, a sizeable number of studies have attempted to evaluate the regeneration properties of inorganic adsorbents $[61,86,138,200,202,212,214-216]$. Nonetheless, scientific studies explicitly examining the thermochemical regeneration of slag-based adsorbents are few and far between $[86,138,212,215]$.

Gao et al. [86] proposed that ethylenediamine and ammonia could be effective eluants in the removal of heavy metal cations from slag-based adsorbents, as they are less aggressive to the slag components compared to other organic and mineral acids. According to Gao et al. [86], cations desorption from slag phases such as akermanite occurs through ion-exchange and complexation processes (Equation (20)).

$$
\overline{\left(\equiv \mathrm{SO}^{-}\right)_{2}} \mathrm{Me}^{2+}+2 \mathrm{Na}^{+}+n \mathrm{NH}_{3} \rightarrow \overline{2\left(\equiv \mathrm{SO}^{-}\right)} \mathrm{Na}^{+}+\left[\mathrm{Me}\left(\mathrm{NH}_{3}\right)\right]^{2+}
$$

Similarly, Zhou and Haynes [212] investigated the desorption behaviour of $\mathrm{Pb}^{2+}$ and $\mathrm{Cd}^{2+}$ ions from BFS in $0.01 \mathrm{M} \mathrm{NaNO}$ electrolyte and $0.1 \mathrm{M} \mathrm{HNO}_{3}$. Desorption of both $\mathrm{Pb}^{2+}$ and $\mathrm{Cd}^{2+}$ was observed to be low in $0.01 \mathrm{M} \mathrm{NaNO}_{3}$, whereas $0.1 \mathrm{M} \mathrm{HNO}_{3}$ was effective in desorbing $\mathrm{Pb}^{2+}$ ions from spent BFS adsorbents, albeit with loss of adsorbent capacity from chemical attack by the aggressive inorganic acid. However, $0.1 \mathrm{M} \mathrm{HNO}_{3}$ proved to be ineffective for desorption of $\mathrm{Cd}^{2+}$ due to the high residual alkalinity of the slag and the strong adsorbate-adsorbent interactions [86]. 
In a recent study, Shao et al. [138] proposed a different approach to mitigating the environmental impact of spent-slag-based adsorbents. In this study, the authors synthesised a novel photocatalyst from the calcination of a spent calcium silicate hydrate (CSH) composite adsorbent for the removal of heavy metal ions from wastewater. The spent CSH was then loaded with copper (CSH-Cu composite) and converted into a photocatalyst, via a simple calcination process, for the removal of organic dyes. The $\mathrm{CSH}-\mathrm{Cu}$ composite calcined at $300{ }^{\circ} \mathrm{C}$ achieved over $90 \%$ photocatalytic degradation of methylene blue after $150 \mathrm{~min}$, and was comparable to other novel and commercial photocatalysts. Subsequent photodegradation tests revealed minimal decay of the photocatalyst compared to the initial cycle. This study clearly demonstrates the synergistic applications of solid wastes in the treatment of industrial effluents and wastewaters.

\subsubsection{Challenges to Regenerability of Slag-Based Adsorbents}

Desorption of cations from spent inorganic adsorbents is favoured by low $\mathrm{pH}[86,138,212,215]$. Essentially, the desorption of metal cations under low $\mathrm{pH}$ conditions can be attributed to (1) desorption and/or dissolution of adsorbed cations, since both their sorption and precipitation are favoured at high $\mathrm{pH}$; (2) strong competition between $\mathrm{H}^{+}$ions and metal cations causing displacement of cations into solution; (3) acid conditions favouring dissolution of $\mathrm{Fe}$ and $\mathrm{Al}$ oxide/silicate adsorption surfaces, thereby releasing the adsorbed and/or surface precipitated ions; and (4) acid reacting with residual alkalinity, thus lowering sorption capacity. Nonetheless, as highlighted above, low $\mathrm{pH}$ results in the degradation and loss of adsorption capacity of spent adsorbents.

Unlike their more expensive counterparts, such as granular activated carbons and other functionalised low-cost adsorbents, slags are low-cost adsorbents that are available in large quantities. The low intrinsic monetary value of slags may not justify the additional costs of regeneration, and thus has limited their exploration as feasible commercial regeneration methods [214]. Furthermore, the chemical heterogeneity of slags and complexity of sorbate-adsorbent interactions further complicates the selection of appropriate solvents and/or control of process variables. Thus, the low regenerability and reusability of spent-slag-based adsorbents is problematic as it increases the risk of secondary pollution and volume of waste materials disposed of in landfills. In order to mitigate the potential environmental impacts of spent-slag-based adsorbents, future studies should therefore focus on methods and techniques to increase the regenerability, reusability and recyclability of these materials [202,212,214].

\subsection{Immobilisation and Stabilisation of Spent-Slag-Based Adsorbents}

\subsubsection{Immobilisation using Cementitious Materials}

Immobilisation of hazardous wastes in cementitious materials is a mature and widely accepted environmental remediation technology. It involves the addition of a cementitious binding agent to encapsulate and reduce the mobility of toxic elements [201,203,206-208,217-219]. Cementitious materials such as ordinary Portland cement (OPC), alkali-activated cement (AAC) and chemically bonded phosphate ceramic (CBPC) not only solidify hazardous wastes by chemical means, but also insolubilize, immobilise and encapsulate the toxic contaminants $[201,217,218]$. In fact, it has been proposed that the immobilisation of contaminants by cementitious materials typically involves their physical encapsulation in structurally integral monolithic phases with reduced long-term TCLPs [201,203,206-208,217-220]. However, despite the plethora of literature on the immobilisation of hazardous wastes in cementitious materials, the literature specific to spent-slag-based adsorbents is limited. The lack of research data in this area thus presents challenges to the immobilisation of spent-slag-based adsorbents, particularly for the bulk slags used as permeable reactive media in constructed wetlands. Therefore, it is imperative for future research to focus on investigating pragmatic immobilisation techniques and the long-term TCLPs of immobilised spent inorganic adsorbents in order to increase the acceptance of slags as bulk adsorbents. 


\subsubsection{Immobilisation by Thermal Vitrification}

Thermal treatment is also one of the proven methods for the inertisation treatment of inorganic hazardous wastes. Thermal vitrification involves the high-temperature transformation of solid wastes into environmentally stable waste forms, such as glass and ceramics, via sintering, vitrification and/or vitrification-controlled crystallisation [201,204,205,209-211,221-223]. Thermal vitrification, in particular, converts inorganic wastes into stable and homogenous glassy phases with and without glass precursors and modifiers [204,209-211]. Chemical and physical encapsulation by thermal vitrification thus creates a homogenous and dense product with improved TLCPs [204,205]. According to Colombo et al. [204], the thermal vitrification of inorganic wastes has several advantages, namely (i) the ability of inorganic glasses to incorporate large amounts of heavy metal ions by chemically binding them in an inorganic amorphous network; (ii) high inertness of inorganic glasses to chemical and biological agents, thereby enabling them to be disposed of in landfills or reused for other applications; (iii) the ability of the process to result in large reductions in volumes of the waste; and (iv) mature technology with well-established costs and operational logistics.

To date, extensive studies have demonstrated that glass and glass ceramic technologies can convert silicate-based inorganic wastes to functional materials with substantial market opportunities, while at the same time, converting hazardous wastes into chemically inert glassy matrices [205,210,221-223]. In particular, several studies have demonstrated the synthesis of glass ceramics from admixtures of slags and other inorganic wastes. An earlier study by Nel and Täbber [222] investigated the synthesis of ceramic tiles from ground blast furnace slags mixed with clay, whiting and quartz. The properties of the cast ceramic products sintered between $1200^{\circ} \mathrm{C}$ and $1250^{\circ} \mathrm{C}$ were comparable to ordinary ceramic flooring materials. Ponsot et al. $[210,211]$ investigated the synthesis of glass ceramics from the low temperature sintering and sinter-crystallisation of admixtures containing fayalite $\left(\mathrm{Fe}_{2} \mathrm{SiO}_{4}\right)$ slags and soda-lime glass. The direct sintering of a slag-soda lime glass mixture produced lightweight glass ceramics with limited water absorption, high chemical stability and mechanical properties comparable to commercial porcelain tiles [211]. Bai et al. [205] synthesised glass ceramics from admixtures of high-carbon ferrochrome slags (HCFS), waste glass, limestone, soda and fluorite using a two-stage heat treatment process. The mechanical properties (104 MPa bending strength and $9860 \mathrm{MPa}$ micro hardness) of the HCFS-based glass ceramics were comparable to those of normal clay-slag-based glass ceramics.

Karayannis et al. [221] synthesised novel sintered clay-based ceramic materials incorporating EAF carbon steelmaking slag. Sintering the extruded admixtures containing 6 mass \% EAF slag around $1100{ }^{\circ} \mathrm{C}$ increased the phase-transformation-induced densification, thereby improving the mechanical performance of the ceramic products. Verbinnen et al. [202] also demonstrated the stabilisation of oxyanion and heavy-metal-cation-laden spent inorganic and iron-based adsorbents in ceramic materials. Heating a mixture of industrial sludge and 3 mass $\%$ spent adsorbent loaded containing $\mathrm{Mo}, \mathrm{Cr}, \mathrm{Ni}, \mathrm{Cu}$, $\mathrm{Zn}, \mathrm{Cd}$ and $\mathrm{Pb}$ to $1100{ }^{\circ} \mathrm{C}$ for 30 min effectively stabilised the heavy metal cations to below regulatory limit TCLP values. Similarly, Rathore and Mondal [214] investigated the stabilisation of arsenic- and fluoride-bearing spent inorganic adsorbents (i.e., thermally treated laterite, acid-base-treated laterite and aluminium oxide/hydroxide nanoparticles) in clay bricks. Various admixtures were prepared, compacted into bricks and sintered in the temperature range of 800 to $1000^{\circ} \mathrm{C}$. In addition to meeting the physical properties stipulated by the Indian and ASTM standards, the maximum solubilities of arsenic $\left(150 \mu \mathrm{g} \mathrm{L}^{-1}\right)$ and fluoride $\left(2.1 \mu \mathrm{g} \mathrm{L}^{-1}\right)$ from the sintered bricks were observed to be below the permissible limits stipulated by USEPA standards [214]. The studies highlighted in this subsection clearly demonstrate the potential to synthesise functional materials with high value and low TCLPs from slag admixtures, albeit with no explicit reference to spent-slag-based adsorbents. The gap in scientific literature thus clearly highlights the opportunities and the need for further research in order to increase the inherent value of spent-slag-based adsorbents. Furthermore, inasmuch as the high costs of thermal energy may create sustainability constraints to the thermal vitrification of spent adsorbents, such costs can, however, be compensated for by the environmental benefits and the recycling and 
reuse opportunities of these glass-based products [204,210]. In conclusion, notwithstanding the current limitations, thermal vitrification technologies still have significant potential in the valorisation treatment of spent-slag-based adsorbents.

\section{Conclusions and Future Prospects}

This paper reviewed the application of ironmaking and steelmaking slags as low-cost adsorbents. The performance of slag-based adsorbents depends on specific properties such as physical, chemical and phase chemical composition, porosity and surface functional properties. The adsorption capacity of slags is controlled by physical properties such as pore structure, pore area, pore volume and internal pore surface area. However, the chemical and geometric heterogeneity of slags has significant effects on their performance as low-cost adsorbents and permeable reactive barrier materials. In particular, the variable pore structure and low specific surface area of slags compared to commercial adsorbents can potentially limit their adsorption capacity in industrial applications. Notwithstanding these challenges, the efficacy of slag-based adsorbents can be significantly enhanced through purposeful activation to increase the specific surface area and density of adsorption sites on the surfaces of adsorbent particles. The synthesis of functionalised adsorbents such as geopolymers, zeolites and layered double hydroxides from aluminosilicate precursors can also significantly increase the utilisation of slags as adsorbents.

The mechanisms of adsorption by ironmaking and steelmaking slags are complex. So far, a limited number of studies have attempted to investigate these adsorption mechanisms in detail. However, the few mechanisms proposed to date appear to be inconsistent even under similar adsorption conditions. This is due to the fact that the chemical and phase heterogeneity of steelmaking slags, coupled with the complexity of adsorption in multi-solute systems, further complicates any attempts to elaborate the mechanisms of adsorption. Thus, detailed studies in multi-solute systems that reflect actual industrial effluent compositions are required in order to understand the competitive metal ion adsorption phenomena. Furthermore, elaborating the mechanistic steps in both single- and multi-solute systems requires further investigations.

The application of slag-based adsorbents is predicted on their environmental performance. In particular, steelmaking slags are typically associated with significant amounts of dissolved and/or entrained alloying elements. This, in turn, constrains the adoption of these materials due to the potential of concomitant dissolution and speciation of these toxic metal species under different environmental conditions. This review paper highlighted potential techniques by which to stabilise the toxic metal species in stable phases in slags in order to reduce their potential leachability. Future studies could focus on investigating the controlled solidification and crystallisation of slags in order to engineer specific adsorptive properties and improve the environmental performance of slag-based adsorbents. In other words, integrating the recovery of alloy species and the stabilisation of dissolved and/or entrained metals is critical to the design of future slag-based adsorbents.

Lastly, one of the major challenges for the use of slag-based adsorbents is the accumulation of solid and liquid wastes loaded with high concentrations of toxic cations and anions. Unfortunately, only a limited number of studies have attempted to evaluate the fate of spent-slag-based adsorbents. Thus, in order to mitigate the environmental challenges associated with disposal of loaded slag-based adsorbents, future research should focus on improving the regeneration, recycling and reuse, and the immobilisation treatment of the spent-slag-based adsorbents.

Author Contributions: Conceptualization, J.M., E.M., N.A.R. and M.J.H.S.; resources, N.A.R., M.J.H.S. and S.N., Writing-Original draft preparation, E.M., J.M., G.S.S., B.M.; Writing-Review and editing, J.M., E.M., G.S.S., S.N., B.M. All authors have read and agreed to the published version of the manuscript.

Funding: This research received no external funding.

Acknowledgments: The authors would like to acknowledge support from the School of Chemical and Metallurgical Engineering, University of Witwatersrand. The authors also acknowledges the support from Mintek and the School of Chemical Engineering, University of Birmingham, United Kingdom. 
Conflicts of Interest: The authors declare no conflict of interest.

\section{References}

1. Dabrowski, A. Adsorption-From theory to practice. Adv. Colloid Interface Sci. 2001, 93, 135-224. [CrossRef]

2. Gupta, V.K.; Carrott, P.; Ribeiro Carrott, M.; Suhas. Low-cost adsorbents: Growing approach to wastewater treatment-A review. Crit. Rev. Environ. Sci. Technol. 2009, 39, 783-842. [CrossRef]

3. Ahmaruzzaman, M. Industrial wastes as low-cost potential adsorbents for the treatment of wastewater laden with heavy metals. Adv. Colloid Interface Sci. 2011, 166, 36-59. [CrossRef] [PubMed]

4. De Gisi, S.; Lofrano, G.; Grassi, M.; Notarnicola, M. Characteristics and adsorption capacities of low-cost sorbents for wastewater treatment: A review. Sustain. Mater. Technol. 2016, 9, 10-40. [CrossRef]

5. Qiu, H.; Lv, L.; Pan, B.-C.; Zhang, Q.-J.; Zhang, W.-M.; Zhang, Q.-X. Critical review in adsorption kinetic models. J. Zhejiang Univ. Sci. A 2009, 10, 716-724. [CrossRef]

6. Zhou, G.; Luo, J.; Liu, C.; Chu, L.; Crittenden, J. Efficient heavy metal removal from industrial melting effluent using fixed-bed process based on porous hydrogel adsorbents. Water Res. 2018, 131, 246-254. [CrossRef]

7. Lai, Y.-C.; Chang, Y.-R.; Chen, M.-L.; Lo, Y.-K.; Lai, J.-Y.; Lee, D.-J. Poly (vinyl alcohol) and alginate cross-linked matrix with immobilized Prussian blue and ion exchange resin for cesium removal from waters. Bioresour. Technol. 2016, 214, 192-198. [CrossRef]

8. Ruthven, D.M. Principles of Adsorption and Adsorption Processes; John Wiley \& Sons: Hoboken, NJ, USA, 1984.

9. El-Naas, M.H.; Alhaija, M.A. Modeling of Adsorption Processes. In Mathematical Modelling; Christopher Brennan, R., Ed.; Nova Publishers Inc.: Hauppauge, NY, USA, 2011.

10. Buekens, A.; Zyaykina, N. Adsorbents and adsorption processes for pollution control. Pollut. Control Technol. 2001, 2, 1-10.

11. Menendez-Diaz, J.; Martín-Gullón, I. Types of Carbon Adsorbents and Their Production. In Interface Science and Technology; Elsevier: Amsterdam, The Netherlands, 2006; Volume 7, pp. 1-47.

12. Zheng, C.; Zhao, L.; Zhou, X.; Fu, Z.; Li, A. Treatment technologies for organic wastewater. Water Treat. 2013, 11, 249-286.

13. Simate, G.S.; Maledi, N.; Ochieng, A.; Ndlovu, S.; Zhang, J.; Walubita, L.F. Coal-based adsorbents for water and wastewater treatment. J. Environ. Chem. Eng. 2016, 4, 2291-2312. [CrossRef]

14. Bailey, S.E.; Olin, T.J.; Bricka, R.M.; Adrian, D.D. A review of potentially low-cost sorbents for heavy metals. Water Res. 1999, 33, 2469-2479. [CrossRef]

15. Dimitrova, S.; Nikolov, V.; Mehandjiev, D. Effect of the heat treatment on the morphology and sorption ability to metal ions of metallurgical slag. J. Mater. Sci. 2001, 36, 2639-2643. [CrossRef]

16. Barakat, M. New trends in removing heavy metals from industrial wastewater. Arab. J. Chem. 2011, 4, 361-377. [CrossRef]

17. Sud, D.; Mahajan, G.; Kaur, M. Agricultural waste material as potential adsorbent for sequestering heavy metal ions from aqueous solutions-A review. Bioresour. Technol. 2008, 99, 6017-6027. [CrossRef]

18. Kurniawan, T.A.; Chan, G.Y.; Lo, W.-H.; Babel, S. Comparisons of low-cost adsorbents for treating wastewaters laden with heavy metals. Sci. Total Environ. 2006, 366, 409-426. [CrossRef]

19. Dimitrova, S.; Mehanjiev, D. Interaction of blast-furnace slag with heavy metal ions in water solutions. Water Res. 2000, 34, 1957-1961. [CrossRef]

20. Gaskell, D.R. The Determination of Phase Diagrams for Slag Systems. In Methods for Phase Diagram Determination; Elsevier: Amsterdam, The Netherlands, 2007; pp. 442-458.

21. Reuter, M.; Xiao, Y.; Boin, U. Recycling and Environmental Issues of Metallurgical Slags and Salt Fluxes. In Proceedings of the VII International Conference on Molten Slags Fluxes and Salts, The South African Institute of Mining and Metallurgy, Johannesburg, South African, 25-28 January 2004; pp. 349-356.

22. Matinde, E.; Simate, G.; Ndlovu, S. Mining and metallurgical wastes: A review of recycling and re-use practices. J. S. Afr. Inst. Min. Metall. 2018, 118, 825-844. [CrossRef]

23. Ndlovu, S.; Simate, G.S.; Matinde, E. Waste Production and Utilization in the Metal Extraction Industry; CRC Press: Boca Raton, FL, USA, 2017.

24. Piatak, N.M.; Parsons, M.B.; Seal, R.R., II. Characteristics and environmental aspects of slag: A review. Appl. Geochem. 2015, 57, 236-266. [CrossRef] 
25. Mercado-Borrayo, B.; González-Chávez, J.; Ramírez-Zamora, R.; Schouwenaars, R. Valorization of metallurgical slag for the treatment of water pollution: An emerging technology for resource conservation and re-utilization. J. Sustain. Metall. 2018, 4, 50-67. [CrossRef]

26. Tan, K.; Hameed, B. Insight into the adsorption kinetics models for the removal of contaminants from aqueous solutions. J. Taiwan Inst. Chem. Eng. 2017, 74, 25-48. [CrossRef]

27. Verhaverbeke, S. Cleaning of Trace Metallic Impurities from Solid Substrates Using Liquid Media. In Handbook for Cleaning/Decontamination of Surfaces; Elsevier: Amsterdam, The Netherlands, 2007; pp. 485-538.

28. Ho, Y.; McKay, G. A comparison of chemisorption kinetic models applied to pollutant removal on various sorbents. Process Saf. Environ. Prot. 1998, 76, 332-340. [CrossRef]

29. Knaebel, K.S. Adsorbent selection. Accessed 2011, 6, 1-23.

30. El-Khaiary, M.I.; Malash, G.F.; Ho, Y.-S. On the use of linearized pseudo-second-order kinetic equations for modeling adsorption systems. Desalination 2010, 257, 93-101. [CrossRef]

31. Foo, K.Y.; Hameed, B.H. Insights into the modeling of adsorption isotherm systems. Chem. Eng. J. 2010, 156, 2-10. [CrossRef]

32. Al-Anber, M.A. Thermodynamics Approach in the Adsorption of Heavy Metals. In Thermodynamics-Interaction Studies-Solids, Liquids and Gases; IntechOpen: London, UK, 2011.

33. Simonin, J.-P. On the comparison of pseudo-first order and pseudo-second order rate laws in the modeling of adsorption kinetics. Chem. Eng. J. 2016, 300, 254-263. [CrossRef]

34. Gupta, S.S.; Bhattacharyya, K.G. Kinetics of adsorption of metal ions on inorganic materials: A review. Adv. Colloid Interface Sci. 2011, 162, 39-58. [CrossRef]

35. Largitte, L.; Pasquier, R. A review of the kinetics adsorption models and their application to the adsorption of lead by an activated carbon. Chem. Eng. Res. Des. 2016, 109, 495-504. [CrossRef]

36. Yildirim, I.Z.; Prezzi, M. Chemical, mineralogical, and morphological properties of steel slag. Adv. Civ. Eng. 2011, 2011. [CrossRef]

37. Association, W.S. Steel Industry by-Products. World Steel Association, 2018; Volume 2018. Available online: https://www.worldsteel.org/en/dam/jcr:1b916a916d-906fd-914e984-b935d-c911d911d918df914/Fact_ By-products_2018.pdf (accessed on 6 November 2018).

38. Barati, M.; Esfahani, S.; Utigard, T. Energy recovery from high temperature slags. Energy 2011, 36, 5440-5449. [CrossRef]

39. Shi, C. Steel slag-Its production, processing, characteristics, and cementitious properties. J. Mater. Civ. Eng. 2004, 16, 230-236. [CrossRef]

40. Zheng, G.H.; Kozinsk, J.A. Solid waste remediation in the metallurgical industry: Application and environmental impact. Environ. Prog. 1996, 15, 283-292. [CrossRef]

41. Talling, B.; Krivenko, P. Blast furnace slag-the ultimate binder. In Waste Materials Used in Concrete Manufacturing; Elsevier: Amsterdam, The Netherlands, 1996; pp. 235-289.

42. Dimitrova, S.; Mehandgiev, D. Lead removal from aqueous solutions by granulated blast-furnace slag. Water Res. 1998, 32, 3289-3292. [CrossRef]

43. Rao, S.R. Resource Recovery and Recycling from Metallurgical Wastes; Elsevier: Amsterdam, The Netherlands, 2011; Volume 7.

44. EUROSLAG. Ferrous slag: General information. Available online: https://www.euroslag.com/products/ (accessed on 6 November 2018).

45. Rao, S.R. Metallurgical Slags, Dust and Fumes. In Waste Management Series; Elsevier: Amsterdam, The Netherlands, 2006; Volume 7, pp. 269-327.

46. Johansson, L. Blast furnace slag as phosphorus sorbents-Column studies. Sci. Total Environ. 1999, 229, 89-97. [CrossRef]

47. About Iron and Steel Slag. Available online: http://www.slg.jp/e/slag/character.html (accessed on 6 November 2018).

48. Das, B.; Prakash, S.; Reddy, P.; Misra, V. An overview of utilization of slag and sludge from steel industries. Resour. Conserv. Recycl. 2007, 50, 40-57. [CrossRef]

49. Yi, H.; Xu, G.; Cheng, H.; Wang, J.; Wan, Y.; Chen, H. An overview of utilization of steel slag. Procedia Environ. Sci. 2012, 16, 791-801. [CrossRef]

50. Waligora, J.; Bulteel, D.; Degrugilliers, P.; Damidot, D.; Potdevin, J.; Measson, M. Chemical and mineralogical characterizations of LD converter steel slags: A multi-analytical techniques approach. Mater. Charact. 2010, 61, 39-48. [CrossRef] 
51. Setién, J.; Hernández, D.; González, J. Characterization of ladle furnace basic slag for use as a construction material. Constr. Build. Mater. 2009, 23, 1788-1794. [CrossRef]

52. Tossavainen, M.; Engstrom, F.; Yang, Q.; Menad, N.; Larsson, M.L.; Bjorkman, B. Characteristics of steel slag under different cooling conditions. Waste Manag. 2007, 27, 1335-1344. [CrossRef]

53. Shen, H.; Forssberg, E. An overview of recovery of metals from slags. Waste Manag. 2003, 23, 933-949. [CrossRef]

54. Durinck, D.; Engström, F.; Arnout, S.; Heulens, J.; Jones, P.T.; Björkman, B.; Blanpain, B.; Wollants, P. Hot stage processing of metallurgical slags. Resour. Conserv. Recycl. 2008, 52, 1121-1131. [CrossRef]

55. Shen, H.; Forssberg, E.; Nordström, U. Physicochemical and mineralogical properties of stainless steel slags oriented to metal recovery. Resour. Conserv. Recycl. 2004, 40, 245-271. [CrossRef]

56. Huaiwei, Z.; Xin, H. An overview for the utilization of wastes from stainless steel industries. Resour. Conserv. Recycl. 2011, 55, 745-754. [CrossRef]

57. Mihailova, I.; Dimitrova, S.; Mehandjiev, D. Effect of the thermal treatment on the $\mathrm{Pb}$ (II) adsorption ability of blast furnace slag. J. Chem. Technol. Metall. 2013, 48, 72-79.

58. Rađenović, A.; Malina, J.; Sofilić, T. Characterization of ladle furnace slag from carbon steel production as a potential adsorbent. Adv. Mater. Sci. Eng. 2013, 2013. [CrossRef]

59. Xue, Y.; Hou, H.; Zhu, S. Adsorption removal of reactive dyes from aqueous solution by modified basic oxygen furnace slag: Isotherm and kinetic study. Chem. Eng. J. 2009, 147, 272-279. [CrossRef]

60. Islam, M.; Patel, R. Thermal activation of basic oxygen furnace slag and evaluation of its fluoride removal efficiency. Chem. Eng. J. 2011, 169, 68-77. [CrossRef]

61. Gupta, V.K. Equilibrium uptake, sorption dynamics, process development, and column operations for the removal of copper and nickel from aqueous solution and wastewater using activated slag, a low-cost adsorbent. Ind. Eng. Chem. Res. 1998, 37, 192-202. [CrossRef]

62. Xue, Y.; Wu, S.; Zhou, M. Adsorption characterization of $\mathrm{Cu}$ (II) from aqueous solution onto basic oxygen furnace slag. Chem. Eng. J. 2013, 231, 355-364. [CrossRef]

63. Yu, J.; Liang, W.; Wang, L.; Li, F.; Zou, Y.; Wang, H. Phosphate removal from domestic wastewater using thermally modified steel slag. J. Environ. Sci. 2015, 31, 81-88. [CrossRef]

64. Yang, L.; Qian, X.; Wang, Z.; Li, Y.; Bai, H.; Li, H. Steel slag as low-cost adsorbent for the removal of phenanthrene and naphthalene. Adsorpt. Sci. Technol. 2018, 36, 1160-1177. [CrossRef]

65. Li, J.; Wu, B.; Zhou, T.; Chai, X. Preferential removal of phosphorus using modified steel slag and cement combination for its implications in engineering applications. Environ. Technol. Innov. 2018, 10, 264-274. [CrossRef]

66. Duan, J.; Su, B. Removal characteristics of Cd (II) from acidic aqueous solution by modified steel-making slag. Chem. Eng. J. 2014, 246, 160-167. [CrossRef]

67. Curković, L.; Cerjan-Stefanović, S.; Rastovean-Mioe, A. Batch $\mathrm{Pb}^{2+}$ and $\mathrm{Cu}^{2+}$ removal by electric furnace slag. Water Res. 2001, 35, 3436-3440. [CrossRef]

68. Deng, S. Sorbent technology. Encycl. Chem. Process. 2006, 1, 2825-2845.

69. Liu, S.-Y.; Gao, J.; Yang, Y.-J.; Yang, Y.-C.; Ye, Z.-X. Adsorption intrinsic kinetics and isotherms of lead ions on steel slag. J. Hazard. Mater. 2010, 173, 558-562. [CrossRef]

70. Dimitrova, S. Metal sorption on blast-furnace slag. Water Res. 1996, 30, 228-232. [CrossRef]

71. Feng, D.; Van Deventer, J.; Aldrich, C. Removal of pollutants from acid mine wastewater using metallurgical by-product slags. Sep. Purif. Technol. 2004, 40, 61-67. [CrossRef]

72. Chen, X.; Hou, W.; Song, G.; Wang, Q. Adsorption of $\mathrm{Cu}, \mathrm{Cd}, \mathrm{Zn}$ and $\mathrm{Pb}$ ions from aqueous solutions by electric arc furnaceslag and the effects of $\mathrm{pH}$ and grain size. Chem. Biochem. Eng. Q 2011, 25, 105-114.

73. Zahar, M.S.M.; Kusin, F.M.; Muhammad, S.N. Adsorption of manganese in aqueous solution by steel slag. Procedia Environ. Sci. 2015, 30, 145-150. [CrossRef]

74. Runtti, H.; Luukkonen, T.; Niskanen, M.; Tuomikoski, S.; Kangas, T.; Tynjälä, P.; Tolonen, E.-T.; Sarkkinen, M.; Kemppainen, K.; Rämö, J. Sulphate removal over barium-modified blast-furnace-slag geopolymer. J. Hazard. Mater. 2016, 317, 373-384. [CrossRef]

75. Bodurtha, P.; Brassard, P. Neutralization of acid by steel-making slags. Environ. Technol. 2000, 21, 1271-1281. [CrossRef]

76. Yan, J.; Moreno, L.; Neretnieks, I. The long-term acid neutralizing capacity of steel slag. Waste Manag. 2000, 20, 217-223. [CrossRef] 
77. Xue, Y.; Hou, H.; Zhu, S. Competitive adsorption of copper (II), cadmium (II), lead (II) and zinc (II) onto basic oxygen furnace slag. J. Hazard. Mater. 2009, 162, 391-401. [CrossRef] [PubMed]

78. Akcil, A.; Koldas, S. Acid Mine Drainage (AMD): Causes, treatment and case studies. J. Clean. Prod. 2006, 14, 1139-1145. [CrossRef]

79. Kuyucak, N. Role of microorganisms in mining: Generation of acid rock drainage and its mitigation and treatment. EJMP EP 2002, 2, 179-196.

80. Robb, G.A.; Robinson, J.D. Acid drainage from mines. Geogr. J. 1995, 161, 47-54. [CrossRef]

81. Fu, F.; Wang, Q. Removal of heavy metal ions from wastewaters: A review. J. Environ. Manag. 2011, 92, 407-418. [CrossRef]

82. Huisman, J.L.; Schouten, G.; Schultz, C. Biologically produced sulphide for purification of process streams, effluent treatment and recovery of metals in the metal and mining industry. Hydrometallurgy 2006, 83, 106-113. [CrossRef]

83. Kim, D.-H.; Shin, M.-C.; Choi, H.-D.; Seo, C.-I.; Baek, K. Removal mechanisms of copper using steel-making slag: Adsorption and precipitation. Desalination 2008, 223, 283-289. [CrossRef]

84. Gao, Y.; Jiang, J.; Tian, S.; Li, K.; Yan, F.; Liu, N.; Yang, M.; Chen, X. BOF steel slag as a low-cost sorbent for vanadium (V) removal from soil washing effluent. Sci. Rep. 2017, 7, 11177. [CrossRef]

85. Han, C.; Jiao, Y.; Wu, Q.; Yang, W.; Yang, H.; Xue, X. Kinetics and mechanism of hexavalent chromium removal by basic oxygen furnace slag. J. Environ. Sci. 2016, 46, 63-71. [CrossRef]

86. Gao, Y.-M.; Sengupta, A.K.; Simpson, D. A new hybrid inorganic sorbent for heavy metals removal. Water Res. 1995, 29, 2195-2205. [CrossRef]

87. Yamashita, K.; Ikehata, T.; Tate, K.; Nakahara, K. Method of Removing Dissolved Heavy Metals from Aqueous Waste Liquids. US Patent 4,377,483, 22 March 1983.

88. Dushina, A.; Aleskovski, V. Ion exchange as first stage of the solid substance transformation into electrolytic solutions. J. Appl. Chem. 1976, 49, 41.

89. Liu, S.-Y.; Gao, J.; Qu, B.; Yang, Y. Adsorption Behaviors of Heavy Metal Ions by Steel Slag-An Industrial Solidwaste. In Proceedings of the 2009 3rd International Conference on Bioinformatics and Biomedical Engineering, Beijing, China, 11-16 June 2009; pp. 1-4.

90. Name, T.; Sheridan, C. Remediation of acid mine drainage using metallurgical slags. Miner. Eng. 2014, 64, 15-22. [CrossRef]

91. Repo, E.; Warchoł, J.K.; Westholm, L.J.; Sillanpää, M. Steel slag as a low-cost sorbent for metal removal in the presence of chelating agents. J. Ind. Eng. Chem. 2015, 27, 115-125. [CrossRef]

92. Nguyen, T.C.; Loganathan, P.; Nguyen, T.V.; Kandasamy, J.; Naidu, R.; Vigneswaran, S. Adsorptive removal of five heavy metals from water using blast furnace slag and fly ash. Environ. Sci. Pollut. Res. 2018, 25, 20430-20438. [CrossRef]

93. Huang, C.; Rhoads, E.A. Adsorption of Zn (II) onto hydrous aluminosilicates. J. Colloid Interface Sci. 1989, 131, 289-306. [CrossRef]

94. Gadde, R.R.; Laitinen, H.A. Heavy metal adsorption by hydrous iron and manganese oxides. Anal. Chem. 1974, 46, 2022-2026. [CrossRef]

95. Kosmulski, M. The pH-dependent surface charging and the points of zero charge. J. Colloid Interface Sci. 2002, 253, 77-87. [CrossRef]

96. Ortiz, N.; Pires, M.; Bressiani, J. Use of steel converter slag as nickel adsorber to wastewater treatment. Waste Manag. 2001, 21, 631-635. [CrossRef]

97. Huifen, Y.; Wen, M.; Weina, Z.; Zhiyong, W. Steel Slag as Multi-Functional Material for Removal of Heavy Metal Ions in Wastewater. In Proceedings of the 2011 International Conference on Computer Distributed Control and Intelligent Environmental Monitoring, Changsha, China, 19-20 February 2011; pp. 1287-1290.

98. Choi, K.; Lee, S.; Park, J.O.; Park, J.-A.; Cho, S.-H.; Lee, S.Y.; Lee, J.H.; Choi, J.-W. Chromium removal from aqueous solution by a PEI-silica nanocomposite. Sci. Rep. 2018, 8, 1438. [CrossRef]

99. Dakiky, M.; Khamis, M.; Manassra, A.; Mer'Eb, M. Selective adsorption of chromium (VI) in industrial wastewater using low-cost abundantly available adsorbents. Adv. Environ. Res. 2002, 6, 533-540. [CrossRef]

100. Benjamin, M.M.; Leckie, J.O. Competitive adsorption of $\mathrm{Cd}, \mathrm{Cu}, \mathrm{Zn}$, and $\mathrm{Pb}$ on amorphous iron oxyhydroxide. J. Colloid Interface Sci. 1981, 83, 410-419. [CrossRef] 
101. Srivastava, V.C.; Swamy, M.M.; Mall, I.D.; Prasad, B.; Mishra, I.M. Adsorptive removal of phenol by bagasse fly ash and activated carbon: Equilibrium, kinetics and thermodynamics. Colloids Surf. A Physicochem. Eng. Asp. 2006, 272, 89-104. [CrossRef]

102. Weber, W.J.; Morris, J.C. Kinetics of adsorption on carbon from solution. J. Sanit. Eng. Div. 1963, 89, 31-60.

103. Kaczmarski, K.; Bellot, J.C. Effect of particle-size distribution and particle porosity changes on mass-transfer kinetics. Acta Chromatogr. 2003, 13, 22-37.

104. Müller, B.R. Effect of particle size and surface area on the adsorption of albumin-bonded bilirubin on activated carbon. Carbon 2010, 48, 3607-3615. [CrossRef]

105. Pang, Y.; Yu, J.; Tang, L.; Zeng, G.; Zhu, C.; Wei, X. Magnetic Nanohybrid Materials for Water-Pollutant Removal. In Nanohybrid and Nanoporous Materials for Aquatic Pollution Control; Elsevier: Amsterdam, The Netherlands, 2019; pp. 1-30.

106. Plazinski, W.; Rudzinski, W. Kinetics of adsorption at solid/solution interfaces controlled by intraparticle diffusion: A theoretical analysis. J. Phys. Chem. C 2009, 113, 12495-12501. [CrossRef]

107. Mobasherpour, I.; Salahi, E.; Pazouki, M. Comparative of the removal of $\mathrm{Pb}^{2+}, \mathrm{Cd}^{2+}$ and $\mathrm{Ni}^{2+}$ by nano crystallite hydroxyapatite from aqueous solutions: Adsorption isotherm study. Arab. J. Chem. 2012, 5, 439-446. [CrossRef]

108. Mihajlović, M.T.; Lazarević, S.S.; Janković-Častvan, I.M.; Jokić, B.M.; Janaćković, D.T.; Petrović, R.D. A comparative study of the removal of lead, cadmium and zinc ions from aqueous solutions by natural and Fe (III)-modified zeolite. Chem. Ind. Chem. Eng. Q. 2014, 20, 283-293. [CrossRef]

109. Borhade, A.V.; Kshirsagar, T.A.; Dholi, A.G.; Agashe, J.A. Removal of heavy metals $\mathrm{Cd}^{2+}, \mathrm{Pb}^{2+}, \mathrm{and} \mathrm{Ni}^{2+}$ from aqueous solutions using synthesized azide cancrinite, $\mathrm{Na} 8\left[\mathrm{AlSiO}_{4}\right] 6(\mathrm{~N} 3) 2.4\left(\mathrm{H}_{2} \mathrm{O}\right)$ 4.6. J. Chem. Eng. Data 2015, 60, 586-593. [CrossRef]

110. Marcus, Y. Thermodynamics of solvation of ions. Part 5-Gibbs free energy of hydration at 298.15 K. J. Chem. Soc. Faraday Trans. 1991, 87, 2995-2999. [CrossRef]

111. Chen, S.; Ma, Y.; Chen, L.; Xian, K. Adsorption of aqueous $\mathrm{Cd}^{2+}, \mathrm{Pb}^{2+}, \mathrm{Cu}^{2+}$ ions by nano-hydroxyapatite: Single-and multi-metal competitive adsorption study. Geochem. J. 2010, 44, 233-239. [CrossRef]

112. Zhou, X.; Xue, X.; Jiang, W. Study on adsorption of heavy metal ion in metallurgical wastewater by sepiolite. In Proceedings of the 2011 2nd International Conference on Environmental Science and Development IPCBEE, Singapore, 26-28 February 2011.

113. Neris, J.B.; Luzardo, F.H.M.; da Silva, E.G.P.; Velasco, F.G. Evaluation of adsorption processes of metal ions in multi-element aqueous systems by lignocellulosic adsorbents applying different isotherms: A critical review. Chem. Eng. J. 2019, 357, 404-420. [CrossRef]

114. Ho, Y.-S. Second-order kinetic model for the sorption of cadmium onto tree fern: A comparison of linear and non-linear methods. Water Res. 2006, 40, 119-125. [CrossRef]

115. Boyd, G.; Adamson, A.; Myers, L., Jr. The exchange adsorption of ions from aqueous solutions by organic zeolites. II. Kinetics1. J. Am. Chem. Soc. 1947, 69, 2836-2848. [CrossRef] [PubMed]

116. Motsi, T.; Rowson, N.; Simmons, M. Adsorption of heavy metals from acid mine drainage by natural zeolite. Int. J. Miner. Process. 2009, 92, 42-48. [CrossRef]

117. Rasaki, S.A.; Bingxue, Z.; Guarecuco, R.; Thomas, T.; Minghui, Y. Geopolymer for use in heavy metals adsorption, and advanced oxidative processes: A critical review. J. Clean. Prod. 2018, 213, 42-58. [CrossRef]

118. Zhang, Y.J.; Liu, L.C.; Xu, Y.; Wang, Y.C. A new alkali-activated steel slag-based cementitious material for photocatalytic degradation of organic pollutant from waste water. J. Hazard. Mater. 2012, 209, 146-150. [CrossRef] [PubMed]

119. Luukkonen, T.; Runtti, H.; Niskanen, M.; Tolonen, E.-T.; Sarkkinen, M.; Kemppainen, K.; Rämö, J.; Lassi, U. Simultaneous removal of $\mathrm{Ni}$ (II), As (III), and Sb (III) from spiked mine effluent with metakaolin and blast-furnace-slag geopolymers. J. Environ. Manag. 2016, 166, 579-588. [CrossRef] [PubMed]

120. Luukkonen, T.; Abdollahnejad, Z.; Yliniemi, J.; Kinnunen, P.; Illikainen, M. One-part alkali-activated materials: A review. Cem. Concr. Res. 2018, 103, 21-34. [CrossRef]

121. Provis, J.L. Alkali-activated materials. Cem. Concr. Res. 2018, 114, 40-48. [CrossRef]

122. Provis, J.L.; Lukey, G.C.; van Deventer, J.S. Do geopolymers actually contain nanocrystalline zeolites? A reexamination of existing results. Chem. Mater. 2005, 17, 3075-3085. [CrossRef]

123. El-Eswed, B.I. Solidification Versus Adsorption for Immobilization of Pollutants in Geopolymeric Materials: A Review; InTech Open: London, UK, 2018. 
124. Ahn, J.S.; Chon, C.-M.; Moon, H.-S.; Kim, K.-W. Arsenic removal using steel manufacturing byproducts as permeable reactive materials in mine tailing containment systems. Water Res. 2003, 37, 2478-2488. [CrossRef]

125. Pratt, C.; Shilton, A.; Pratt, S.; Haverkamp, R.G.; Bolan, N.S. Phosphorus removal mechanisms in active slag filters treating waste stabilization pond effluent. Environ. Sci. Technol. 2007, 41, 3296-3301. [CrossRef] [PubMed]

126. Lee, M.S.; Drizo, A.; Rizzo, D.M.; Druschel, G.; Hayden, N.; Twohig, E. Evaluating the efficiency and temporal variation of pilot-scale constructed wetlands and steel slag phosphorus removing filters for treating dairy wastewater. Water Res. 2010, 44, 4077-4086. [CrossRef] [PubMed]

127. Vohla, C.; Kõiv, M.; Bavor, H.J.; Chazarenc, F.; Mander, Ü. Filter materials for phosphorus removal from wastewater in treatment wetlands-A review. Ecol. Eng. 2011, 37, 70-89. [CrossRef]

128. Barca, C.; Meyer, D.; Liira, M.; Drissen, P.; Comeau, Y.; Andrès, Y.; Chazarenc, F. Steel slag filters to upgrade phosphorus removal in small wastewater treatment plants: Removal mechanisms and performance. Ecol. Eng. 2014, 68, 214-222. [CrossRef]

129. Barca, C.; Troesch, S.; Meyer, D.; Drissen, P.; Andres, Y.; Chazarenc, F. Steel slag filters to upgrade phosphorus removal in constructed wetlands: Two years of field experiments. Environ. Sci. Technol. 2012, 47, 549-556. [CrossRef]

130. Claveau-Mallet, D.; Courcelles, B.; Comeau, Y. Phosphorus removal by steel slag filters: Modeling dissolution and precipitation kinetics to predict longevity. Environ. Sci. Technol. 2014, 48, 7486-7493. [CrossRef]

131. Claveau-Mallet, D.; Wallace, S.; Comeau, Y. Model of phosphorus precipitation and crystal formation in electric arc furnace steel slag filters. Environ. Sci. Technol. 2012, 46, 1465-1470. [CrossRef] [PubMed]

132. Claveau-Mallet, D.; Wallace, S.; Comeau, Y. Removal of phosphorus, fluoride and metals from a gypsum mining leachate using steel slag filters. Water Res. 2013, 47, 1512-1520. [CrossRef] [PubMed]

133. Sugano, Y.; Sahara, R.; Murakami, T.; Narushima, T.; Iguchi, Y.; Ouchi, C. Hydrothermal synthesis of zeolite A using blast furnace slag. ISIJ Int. 2005, 45, 937-945. [CrossRef]

134. Kuwahara, Y.; Ohmichi, T.; Mori, K.; Katayama, I.; Yamashita, H. Synthesis of zeolite from steel slag and its application as a support of nano-sized TiO 2 photocatalyst. J. Mater. Sci. 2008, 43, 2407-2410. [CrossRef]

135. Li, Y.; Peng, T.; Man, W.; Ju, L.; Zheng, F.; Zhang, M.; Guo, M. Hydrothermal synthesis of mixtures of NaA zeolite and sodalite from Ti-bearing electric arc furnace slag. Rsc Adv. 2016, 6, 8358-8366. [CrossRef]

136. Kuwahara, Y.; Ohmichi, T.; Kamegawa, T.; Mori, K.; Yamashita, H. A novel conversion process for waste slag: Synthesis of a hydrotalcite-like compound and zeolite from blast furnace slag and evaluation of adsorption capacities. J. Mater. Chem. 2010, 20, 5052-5062. [CrossRef]

137. Kuwahara, Y.; Tamagawa, S.; Fujitani, T.; Yamashita, H. A novel conversion process for waste slag: Synthesis of calcium silicate hydrate from blast furnace slag and its application as a versatile adsorbent for water purification. J. Mater. Chem. A 2013, 1,7199-7210. [CrossRef]

138. Shao, N.; Tang, S.; Liu, Z.; Li, L.; Yan, F.; Liu, F.; Li, S.; Zhang, Z. Hierarchically structured calcium silicate hydrate-based nanocomposites derived from steel slag for highly efficient heavy metal removal from wastewater. Acs Sustain. Chem. Eng. 2018, 6, 14926-14935. [CrossRef]

139. Yang, L.; Yang, M.; Xu, P.; Zhao, X.; Bai, H.; Li, H. Characteristics of nitrate removal from aqueous solution by modified steel slag. Water 2017, 9, 757. [CrossRef]

140. Allahverdi, A.; Maleki, A.; Mahinroosta, M. Chemical activation of slag-blended Portland cement. J. Build. Eng. 2018, 18, 76-83. [CrossRef]

141. Sobolev, K. Mechano-chemical modification of cement with high volumes of blast furnace slag. Cem. Concr. Compos. 2005, 27, 848-853. [CrossRef]

142. Boldyrev, V.V. Mechanochemistry and mechanical activation of solids. Russ. Chem. Rev. 2006, 75, 177. [CrossRef]

143. Kumar, S.; Kumar, R.; Bandopadhyay, A.; Alex, T.; Kumar, B.R.; Das, S.K.; Mehrotra, S. Mechanical activation of granulated blast furnace slag and its effect on the properties and structure of portland slag cement. Cem. Concr. Compos. 2008, 30, 679-685. [CrossRef]

144. Andini, S.; Cioffi, R.; Colangelo, F.; Montagnaro, F.; Santoro, L. Effect of mechanochemical processing on adsorptive properties of blast furnace slag. J. Environ. Eng. 2013, 139, 1446-1453. [CrossRef]

145. Komnitsas, K.; Zaharaki, D. Geopolymerisation: A review and prospects for the minerals industry. Miner. Eng. 2007, 20, 1261-1277. [CrossRef] 
146. Zhang, Y.J.; Liu, L.C.; Ni, L.L.; Wang, B.L. A facile and low-cost synthesis of granulated blast furnace slag-based cementitious material coupled with $\mathrm{Fe} 2 \mathrm{O} 3$ catalyst for treatment of dye wastewater. Appl. Catal. B Environ. 2013, 138, 9-16. [CrossRef]

147. Sarkar, C.; Basu, J.K.; Samanta, A.N. Removal of $\mathrm{Ni}^{2+}$ ion from waste water by Geopolymeric Adsorbent derived from LD Slag. J. Water Process Eng. 2017, 17, 237-244. [CrossRef]

148. Waybrant, K.; Blowes, D.; Ptacek, C. Selection of reactive mixtures for use in permeable reactive walls for treatment of mine drainage. Environ. Sci. Technol. 1998, 32, 1972-1979. [CrossRef]

149. Cocos, I.A.; Zagury, G.J.; Clément, B.; Samson, R. Multiple factor design for reactive mixture selection for use in reactive walls in mine drainage treatment. Water Res. 2002, 36, 167-177. [CrossRef]

150. Shabalala, A.N.; Ekolu, S.O.; Diop, S.; Solomon, F. Pervious concrete reactive barrier for removal of heavy metals from acid mine drainage- column study. J. Hazard. Mater. 2017, 323, 641-653. [CrossRef]

151. Sasaki, K.; Nukina, S.; Wilopo, W.; Hirajima, T. Removal of arsenate in acid mine drainage by a permeable reactive barrier bearing granulated blast furnace slag: Column study. Mater. Trans. 2008, 0803030343. [CrossRef]

152. Bowden, L.I.; Jarvis, A.P.; Younger, P.L.; Johnson, K.L. Phosphorus removal from waste waters using basic oxygen steel slag. Environ. Sci. Technol. 2009, 43, 2476-2481. [CrossRef] [PubMed]

153. Westholm, L.J.; Repo, E.; Sillanpää, M. Filter materials for metal removal from mine drainage-A review. Environ. Sci. Pollut. Res. 2014, 21, 9109-9128. [CrossRef] [PubMed]

154. Bothe, J.V.; Brown, P.W. Arsenic immobilization by calcium arsenate formation. Environ. Sci. Technol. 1999, 33, 3806-3811. [CrossRef]

155. Zhu, Y.; Zhang, X.; Xie, Q.; Wang, D.; Cheng, G. Solubility and Stability of Calcium Arsenates at $25^{\circ} \mathrm{C}$. Water Air Soil Pollut. 2006, 169, 221-238. [CrossRef]

156. Pascua, C.S.; Minato, M.; Yokoyama, S.; Sato, T. Uptake of dissolved arsenic during the retrieval of silica from spent geothermal brine. Geothermics 2007, 36, 230-242. [CrossRef]

157. Sullivan, C.; Tyrer, M.; Cheeseman, C.R.; Graham, N.J. Disposal of water treatment wastes containing arsenic-A review. Sci. Total Environ. 2010, 408, 1770-1778. [CrossRef]

158. Riley, A.L.; Mayes, W.M. Long-term evolution of highly alkaline steel slag drainage waters. Environ. Monit. Assess. 2015, 187, 463. [CrossRef]

159. De Windt, L.; Chaurand, P.; Rose, J. Kinetics of steel slag leaching: Batch tests and modeling. Waste Manag. 2011, 31, 225-235. [CrossRef]

160. Querol, X.; Moreno, N.; Umaña, J.T.; Alastuey, A.; Hernández, E.; Lopez-Soler, A.; Plana, F. Synthesis of zeolites from coal fly ash: An overview. Int. J. Coal Geol. 2002, 50, 413-423. [CrossRef]

161. Jha, B.; Singh, D.N. Fly Ash Zeolites: Innovations, Applications and Directions; Springer: Berlin/Heidelberg, Germany, 2016; Volume 78.

162. Jha, B.; Singh, D. A review on synthesis, characterization and industrial applications of flyash zeolites. J. Mater. Educ. 2011, 33, 65.

163. Gupta, V.; Imran, A. Water treatment: Low-cost alternatives to carbon adsorbents. In Encyclopedia of Surface and Colloid Science; CRC Press: Boca Raton, FL, USA, 2015; pp. 7618-7652.

164. Çoruh, S. The removal of zinc ions by natural and conditioned clinoptilolites. Desalination 2008, 225, 41-57. [CrossRef]

165. Mihaly-Cozmuta, L.; Mihaly-Cozmuta, A.; Peter, A.; Nicula, C.; Tutu, H.; Silipas, D.; Indrea, E. Adsorption of heavy metal cations by Na-clinoptilolite: Equilibrium and selectivity studies. J. Environ. Manag. 2014, 137, 69-80. [CrossRef] [PubMed]

166. Zanin, E.; Scapinello, J.; de Oliveira, M.; Rambo, C.L.; Franscescon, F.; Freitas, L.; de Mello, J.M.M.; Fiori, M.A.; Oliveira, J.V.; Dal Magro, J. Adsorption of heavy metals from wastewater graphic industry using clinoptilolite zeolite as adsorbent. Process Saf. Environ. Prot. 2017, 105, 194-200. [CrossRef]

167. Li, Y.; Bai, P.; Yan, Y.; Yan, W.; Shi, W.; Xu, R. Removal of $\mathrm{Zn}^{2+}, \mathrm{Pb}^{2+}, \mathrm{Cd}^{2+}$, and $\mathrm{Cu}^{2+}$ from aqueous solution by synthetic clinoptilolite. Microporous Mesoporous Mater. 2019, 273, 203-211. [CrossRef]

168. Kuwahara, Y.; Yamashita, H. Synthesis of Ca-based layered double hydroxide from blast furnace slag and its catalytic applications. ISIJ Int. 2015, 55, 1531-1537. [CrossRef]

169. Bagherifam, S.; Komarneni, S.; Lakzian, A.; Fotovat, A.; Khorasani, R.; Huang, W.; Ma, J.; Wang, Y. Evaluation of $\mathrm{Zn}-\mathrm{Al}-\mathrm{SO}_{4}$ layered double hydroxide for the removal of arsenite and arsenate from a simulated soil solution: Isotherms and kinetics. Appl. Clay Sci. 2014, 95, 119-125. [CrossRef] 
170. Baliarsingh, N.; Parida, K.; Pradhan, G. Influence of the nature and concentration of precursor metal ions in the brucite layer of LDHs for phosphate adsorption-a review. Rsc Adv. 2013, 3, 23865-23878. [CrossRef]

171. Tóth, V.; Sipiczki, M.; Pallagi, A.; Kukovecz, Á.; Kónya, Z.; Sipos, P.; Pálinkó, I. Synthesis and properties of CaAl-layered double hydroxides of hydrocalumite-type. Chem. Pap. 2014, 68, 633-637. [CrossRef]

172. He, X.; Qiu, X.; Hu, C.; Liu, Y. Treatment of heavy metal ions in wastewater using layered double hydroxides: A review. J. Dispers. Sci. Technol. 2018, 39, 792-801. [CrossRef]

173. Matusik, J.; Rybka, K. Removal of Chromates and Sulphates by Mg/Fe LDH and Heterostructured LDH/Halloysite Materials: Efficiency, Selectivity, and Stability of Adsorbents in Single-and Multi-Element Systems. Materials 2019, 12, 1373. [CrossRef] [PubMed]

174. Zhang, H.; Huang, F.; Liu, D.-L.; Shi, P. Highly efficient removal of Cr (VI) from wastewater via adsorption with novel magnetic $\mathrm{Fe}_{3} \mathrm{O}_{4} @ \mathrm{C} @ \mathrm{MgAl}$-layered double-hydroxide. Chin. Chem. Lett. 2015, 26, 1137-1143. [CrossRef]

175. Ling, F.; Fang, L.; Lu, Y.; Gao, J.; Wu, F.; Zhou, M.; Hu, B. A novel CoFe layered double hydroxides adsorbent: High adsorption amount for methyl orange dye and fast removal of $\mathrm{Cr}$ (VI). Microporous Mesoporous Mater. 2016, 234, 230-238. [CrossRef]

176. Gong, J.; Liu, T.; Wang, X.; Hu, X.; Zhang, L. Efficient removal of heavy metal ions from aqueous systems with the assembly of anisotropic layered double hydroxide nanocrystals@ carbon nanosphere. Environ. Sci. Technol. 2011, 45, 6181-6187. [CrossRef]

177. Lu, Y.; Jiang, B.; Fang, L.; Ling, F.; Gao, J.; Wu, F.; Zhang, X. High performance NiFe layered double hydroxide for methyl orange dye and Cr (VI) adsorption. Chemosphere 2016, 152, 415-422. [CrossRef]

178. Outokumpu Stainless, A. Handbook of Stainless Steel; Espoo: Outokumpu OYJ: Helsinki, Finland, 2013.

179. Rai, D.; Eary, L.; Zachara, J.M. Environmental chemistry of chromium. Sci. Total Environ. 1989, 86, 15-23. [CrossRef]

180. Ščančar, J.; Milačič, R. A critical overview of Cr speciation analysis based on high performance liquid chromatography and spectrometric techniques. J. Anal. At. Spectrom. 2014, 29, 427-443. [CrossRef]

181. Pradhan, D.; Sukla, L.B.; Sawyer, M.; Rahman, P.K. Recent bioreduction of hexavalent chromium in wastewater treatment: A review. J. Ind. Eng. Chem. 2017, 55, 1-20. [CrossRef]

182. Xia, S.; Song, Z.; Jeyakumar, P.; Shaheen, S.M.; Rinklebe, J.; Ok, Y.S.; Bolan, N.; Wang, H. A critical review on bioremediation technologies for $\mathrm{Cr}(\mathrm{VI})$-contaminated soils and wastewater. Crit. Rev. Environ. Sci. Technol. 2019, 49, 1027-1078. [CrossRef]

183. Apte, A.D.; Tare, V.; Bose, P. Extent of oxidation of $\mathrm{Cr}$ (III) to $\mathrm{Cr}$ (VI) under various conditions pertaining to natural environment. J. Hazard. Mater. 2006, 128, 164-174. [CrossRef]

184. Ball, J.W.; Nordstrom, D.K. Critical evaluation and selection of standard state thermodynamic properties for chromium metal and its aqueous ions, hydrolysis species, oxides, and hydroxides. J. Chem. Eng. Data 1998, 43, 895-918. [CrossRef]

185. Chaurand, P.; Rose, J.; Briois, V.; Olivi, L.; Hazemann, J.-L.; Proux, O.; Domas, J.; Bottero, J.-Y. Environmental impacts of steel slag reused in road construction: A crystallographic and molecular (XANES) approach. J. Hazard. Mater. 2007, 139, 537-542. [CrossRef] [PubMed]

186. Barnhart, J. Occurrences, uses, and properties of chromium. Regul. Toxicol. Pharmacol. 1997, 26, S3-S7. [CrossRef] [PubMed]

187. Barnhart, J. Chromium chemistry and implications for environmental fate and toxicity. Soil Sediment Contam. 1997, 6, 561-568. [CrossRef]

188. García-Ramos, E.; Romero-Serrano, A.; Zeifert, B.; Flores-Sánchez, P.; Hallen-López, M.; Palacios, E.G. Immobilization of chromium in slags using $\mathrm{MgO}$ and $\mathrm{Al}_{2} \mathrm{O}_{3}$. Steel Res. Int. 2008, 79, 332-339. [CrossRef]

189. Cabrera-Real, H.; Romero-Serrano, A.; Zeifert, B.; Hernandez-Ramirez, A.; Hallen-Lopez, M.; Cruz-Ramirez, A. Effect of $\mathrm{MgO}$ and $\mathrm{CaO} / \mathrm{SiO} 2$ on the immobilization of chromium in synthetic slags. J. Mater. Cycles Waste Manag. 2012, 14, 317-324. [CrossRef]

190. Zhao, Q.; Liu, C.; Cao, L.; Zheng, X.; Jiang, M. Stability of Chromium in Stainless Steel Slag during Cooling. Minerals 2018, 8, 445. [CrossRef]

191. Barbieri, L.; Leonelli, C.; Manfredini, T.; Pellacani, G.C.; Siligardi, C.; Tondello, E.; Bertoncello, R. Solubility, reactivity and nucleation effect of $\mathrm{Cr}_{2} \mathrm{O}_{3}$ in the $\mathrm{CaO}-\mathrm{MgO}-\mathrm{Al}_{2} \mathrm{O}_{3}-\mathrm{SiO}_{2}$ glassy system. J. Mater. Sci. 1994, 29, 6273-6280. [CrossRef] 
192. Kühn, M.; Mudersbach, D. Treatment of Liquid EAF-Slag from Stainless Steelmaking to Produce Environmental Friendly Construction Materials. In Proceedings of the 2nd International Conference on Process Development in Iron and Steelmaking (ScanMet II), Lulea, Sweden, 6-9 June 2004.

193. Tanskanen, P.A.; Makkonen, H.T. Design of Slag Mineralogy and Petrology. Univ. Oulu Outocompu Finl. Glob. Slag Mag. 2007, 5, 16-20.

194. Albertsson, G. Abatement of Chromium Emissions from Steelmaking Slags-Cr Stabilization by Phase Separation. Ph.D. Thesis, KTH Royal Institute of Technology, Stockholm, Sweden, December 2013.

195. Engström, F.; Larsson, M.L.; Samuelsson, C.; Sandström, Å.; Robinson, R.; Björkman, B. Leaching behavior of aged steel slags. Steel Res. Int. 2014, 85, 607-615. [CrossRef]

196. Primavera, A.; Pontoni, L.; Mombelli, D.; Barella, S.; Mapelli, C. EAF slag treatment for inert materials' production. J. Sustain. Metall. 2016, 2, 3-12. [CrossRef]

197. Sahu, N.; Biswas, A.; Kapure, G.U. A short review on utilization of ferrochromium slag. Miner. Process. Extr. Metall. Rev. 2016, 37, 211-219. [CrossRef]

198. Mombelli, D.; Mapelli, C.; Gruttadauria, A.; Baldizzone, C.; Magni, F.; Levrangi, P.L.; Simone, P. Analisys of electric arc furnace slag. Steel Res. Int. 2012, 83, 1012-1019. [CrossRef]

199. Abdullah, M.O. Applied Energy: An Introduction; CRC Press: Boca Raton, FL, USA, 2012.

200. Lata, S.; Singh, P.; Samadder, S. Regeneration of adsorbents and recovery of heavy metals: A review. Int. J. Environ. Sci. Technol. 2015, 12, 1461-1478. [CrossRef]

201. Guo, B.; Liu, B.; Yang, J.; Zhang, S. The mechanisms of heavy metal immobilization by cementitious material treatments and thermal treatments: A review. J. Environ. Manag. 2017, 193, 410-422. [CrossRef] [PubMed]

202. Verbinnen, B.; Block, C.; Van Caneghem, J.; Vandecasteele, C. Recycling of spent adsorbents for oxyanions and heavy metal ions in the production of ceramics. Waste Manag. 2015, 45, 407-411. [CrossRef]

203. Conner, J.R.; Hoeffner, S.L. A critical review of stabilization/solidification technology. Crit. Rev. Environ. Sci. Technol. 1998, 28, 397-462. [CrossRef]

204. Colombo, P.; Brusatin, G.; Bernardo, E.; Scarinci, G. Inertization and reuse of waste materials by vitrification and fabrication of glass-based products. Curr. Opin. Solid State Mater. Sci. 2003, 7, 225-239. [CrossRef]

205. Bai, Z.; Qiu, G.; Peng, B.; Guo, M.; Zhang, M. Synthesis and characterization of glass-ceramics prepared from high-carbon ferrochromium slag. RSC Adv. 2016, 6, 52715-52723. [CrossRef]

206. Kundu, S.; Gupta, A. Immobilization and leaching characteristics of arsenic from cement and/or lime solidified/stabilized spent adsorbent containing arsenic. J. Hazard. Mater. 2008, 153, 434-443. [CrossRef]

207. Shi, C.; Fernandez-Jimenez, A. Stabilization/solidification of hazardous and radioactive wastes with alkali-activated cements. J. Hazard. Mater. 2006, 137, 1656-1663. [CrossRef]

208. Wiles, C.C. A review of solidification/stabilization technology. J. Hazard. Mater. 1987, 14, 5-21. [CrossRef]

209. Rawlings, R. Glass-ceramic matrix composites. Composites 1994, 25, 372-379. [CrossRef]

210. Ponsot, I.; Bernardo, E. Self glazed glass ceramic foams from metallurgical slag and recycled glass. J. Clean. Prod. 2013, 59, 245-250. [CrossRef]

211. Ponsot, I.; Detsch, R.; Boccaccini, A.; Bernardo, E. Waste derived glass ceramic composites prepared by low temperature sintering/sinter-crystallisation. Adv. Appl. Ceram. 2015, 114, S17-S25. [CrossRef]

212. Zhou, Y.-F.; Haynes, R.J. A comparison of inorganic solid wastes as adsorbents of heavy metal cations in aqueous solution and their capacity for desorption and regeneration. Water Air Soil Pollut. 2011, 218, 457-470. [CrossRef]

213. Shahadat, M.; Isamil, S. Regeneration performance of clay-based adsorbents for the removal of industrial dyes: A review. R SC Adv. 2018, 8, 24571-24587.

214. Rathore, V.K.; Mondal, P. Stabilization of arsenic and fluoride bearing spent adsorbent in clay bricks: Preparation, characterization and leaching studies. J. Environ. Manag. 2017, 200, 160-169. [CrossRef] [PubMed]

215. Pyrzynska, K. Removal of cadmium from wastewaters with low-cost adsorbents. J. Environ. Chem. Eng. 2019, 7, 102795. [CrossRef]

216. Mohan, D.; Pittman, C.U., Jr. Arsenic removal from water/wastewater using adsorbents-A critical review. J. Hazard. Mater. 2007, 142, 1-53. [CrossRef]

217. Malviya, R.; Chaudhary, R. Factors affecting hazardous waste solidification/stabilization: A review. J. Hazard. Mater. 2006, 137, 267-276. [CrossRef] [PubMed] 
218. Paria, S.; Yuet, P.K. Solidification-stabilization of organic and inorganic contaminants using portland cement: A literature review. Environ. Rev. 2006, 14, 217-255. [CrossRef]

219. Laforest, G.; Duchesne, J. Immobilization of chromium (VI) evaluated by binding isotherms for ground granulated blast furnace slag and ordinary Portland cement. Cem. Concr. Res. 2005, 35, 2322-2332. [CrossRef]

220. Bhatnagar, A.; Minocha, A.K.; Jeon, B.H.; Park, J.M. Adsorptive removal of cobalt from aqueous solutions by utilizing industrial waste and its cement fixation. Sep. Sci. Technol. 2007, 42, 1255-1266. [CrossRef]

221. Karayannis, V.; Ntampegliotis, K.; Lamprakopoulos, S.; Papapolymerou, G.; Spiliotis, X. Novel sintered ceramic materials incorporated with EAF carbon steel slag. Mater. Res. Express 2017, 4, 015505. [CrossRef]

222. Nel, A. Use of South African blast-furnace slag for ceramic purposes. J. S. Afr. Inst. Min. Metall. 1970, 70, 366-368.

223. Chinnam, R.; Francis, A.; Will, J.; Bernardo, E.; Boccaccini, A. Functional glasses and glass-ceramics derived from iron rich waste and combination of industrial residues. J. Non Cryst. Solids 2013, 365, 63-74. [CrossRef]

(C) 2020 by the authors. Licensee MDPI, Basel, Switzerland. This article is an open access article distributed under the terms and conditions of the Creative Commons Attribution (CC BY) license (http://creativecommons.org/licenses/by/4.0/). 